\title{
A market assessment of greenhouse products and associated rural development in semi-arid regions of Mexico
}

\author{
Edgar Arturo Quevedo-Martinez \\ West Virginia University
}

Follow this and additional works at: https://researchrepository.wvu.edu/etd

\section{Recommended Citation}

Quevedo-Martinez, Edgar Arturo, "A market assessment of greenhouse products and associated rural development in semi-arid regions of Mexico" (2009). Graduate Theses, Dissertations, and Problem Reports. 2824.

https://researchrepository.wvu.edu/etd/2824

This Thesis is protected by copyright and/or related rights. It has been brought to you by the The Research Repository @ WVU with permission from the rights-holder(s). You are free to use this Thesis in any way that is permitted by the copyright and related rights legislation that applies to your use. For other uses you must obtain permission from the rights-holder(s) directly, unless additional rights are indicated by a Creative Commons license in the record and/ or on the work itself. This Thesis has been accepted for inclusion in WVU Graduate Theses, Dissertations, and Problem Reports collection by an authorized administrator of The Research Repository @ WVU. For more information, please contact researchrepository@mail.wvu.edu. 
A market assessment of greenhouse products and associated rural development in semiarid regions of Mexico.

\section{Edgar Arturo Quevedo-Martinez}

Thesis submitted to the

Davis College of Agriculture, Natural Resources and Design

at West Virginia University

in partial fulfillment of the requirements for the degree of

Master of Science in Agricultural \& Resource Economics

Gerard E. D’Souza, Ph. D. Chair

Jason Evans, Ph.D.

Victor Mucino, Ph. D.

Division of Resource Management

Morgantown, West Virginia

2009

Key words: Greenhouses, production cost, marketing, financial feasibility and optimization. 


\title{
ABSTRACT \\ "A market assessment of greenhouse products and associated rural development in semi-arid regions of Mexico."
}

\author{
Edgar Arturo Quevedo-Martinez
}

Greenhouse products represent a feasible alternative for small producers compared to openfield production. Using a combination of enterprise budgeting, capital investment analysis and optimization, we found that under most of the conditions investigated the six different crops investigated are profitable. Greenhouse production has the added benefits of conserving scarce land and water resources, potentially reducing production and market risk, and offering consumers healthful products of good quality, that can contribute to the development of the local economy. One problem is that a larger up-front investment is often essential.

This study focused on three main areas:

1) A production and market assessment.

2) An analysis of governmental policies in Mexico and the USA, especially with respect to exports, and

3) An evaluation of credit programs for small producers. 


\section{Dedication}

To the memory of my father, who with his example always encouraged us to be better and to be good persons. 


\section{Acknowledgments}

Family

To my wife Fabiola for believing in me and for always supporting me with all the sacrifices that she made to help me to achieve this goal.

To my mother who always has supported me and for all her prayer, to my sisters and brother for their wholehearted help for me and my family.

To my family in law for all the support they gave us to obtain this work.

To my nephew Luis Octavio for his help in the production of this thesis

WVU

I want especially to thank my advisor, Dr. Gerard D'Souza, who gave me the opportunity to work with him, his patience and for guiding me in this work.

To my thesis committee, Dr. Victor Muciño and especially to Dr. Jason Evans who also was my teacher, for his patience with me and all his knowledge that helped me to complete this work.

To all my teachers and professors for their knowledge and support that they gave me. Also to Lisa Lewis for assisting me with the paperwork necessary to complete the submission of my thesis and my graduation.

A special thank for my friends Dr. John Sneckenberger and his wife Scottie because of the advice and support that they gave to me all the time that I was in Morgantown.

To professor David Díaz Florian for all his support that he gave me and my family during our stay in West Virginia. 
To all my friends at WVU from whom I learned a lot, specially to Billy Plyler who helped me with the language.

UAQ

I want to specially thank Dr Gilberto Herrera for always believing in me and for giving me the opportunity to undertake this master's degree, for his support, trust and for always helping me when I needed it.

To CPA Fernando Valencia who gave me the opportunity of conducting this study and for his support.

Special thanks to Ing Miguel Rangel for all the knowledge that I have received from him and for giving me the chance to be better and to undertaking this master's degree.

Thanks to my friends Ing. Carlos Molina, Ing. Arturo Jimenez and Ing. Lupano for their support and for help me with my students when I was making my studies.

\section{USAID/HED/TIES Program}

Last, but certainly not the least, to USAID for sponsoring, this study, and the lead PI on this interdisciplinary project, Dr Victor Mucino, for proving the financial support without which this study would not have been possible. 


\section{Table of Contents}

$\begin{array}{ll}\text { ABSTRACT } & 1\end{array}$

DEDICATION

ACKNOWLEDGMENTS iv

TABLE OF CONTENTS vi

List of tables $\quad x$

List of Figures. $\quad x$

Abbreviations $\quad$ xi

$\begin{array}{ll}\text { CHAPTER I } & 1\end{array}$

$\begin{array}{ll}1.1 \text { INTRODUCTION } & 1\end{array}$

1.1.1 Greenhouse Technology 2

1.1.2 Marketing Feasibility 2

1.1.3 Production area $\quad 4$

1.1.4 Geography of Mexico 4

1.1.4.1 Borders.

$\begin{array}{lr}\text { 1.1.4.2 Population. } & 6\end{array}$

1.1.5 Mexico's Topography 6

1.1.6 The economy of Mexico $\quad 6$

$\begin{array}{ll}\text { 1.1.6.1 Trade } & 7\end{array}$

$\begin{array}{ll}\text { 1.1.6.2 Agriculture } & 7\end{array}$

1.1.6.3 Manufacturing and Foreign Investment $\quad 8$

$\begin{array}{lr}\text { 1.1.6.4 Oil and Gas } & 9\end{array}$

1.1.6.5 Transportation and Communications $\quad 9$ 
$\begin{array}{lr}1.3 \text { Background } & 11\end{array}$

$\begin{array}{ll}\text { 1.3.1 Origin of the Greenhouse Industry } & 11\end{array}$

$\begin{array}{lr}\text { 1.3.2 Fresh flowers } & 12\end{array}$

$\begin{array}{ll}\text { 1.3.3 Production Opportunities Near Developed Markets } & 15\end{array}$

$\begin{array}{lr}\text { 1.3.3.1 Small Growers } & 15\end{array}$

$\begin{array}{lr}\text { 1.3.4 Grading and Standards } & 16\end{array}$

$\begin{array}{ll}\text { 1.3.5 The market system } & 16\end{array}$

$\begin{array}{lr}\text { 1.3.6 Advertising } & 17\end{array}$

$\begin{array}{lr}\text { Greenhouse growth in Mexico and Latin America } & 18\end{array}$

$\begin{array}{lr}\text { 1.4 OBJECTIVES } & 20\end{array}$

$\begin{array}{lr}\text { CHAPTER II } & 22\end{array}$

$\begin{array}{lr}2.1 \text { REVIEW OF LITERATURE } & 22\end{array}$

$\begin{array}{lr}\text { CHAPTER III } & 28\end{array}$

$\begin{array}{lr}\text { 3.1 METHODOLOGY AND DATA } & 28\end{array}$

$\begin{array}{lr}\text { 3.1.1 Primary Data } & 28\end{array}$

3.1.2 Production and Market Assessment: $\quad 31$

3.1.3 Governmental policies and Economic Feasibility $\quad 32$

$\begin{array}{ll}\text { CHAPTER IV } & 36\end{array}$

\begin{tabular}{ll}
4.1 & RESULTS \\
\hline
\end{tabular}

4.1.1 Production and Market Assessment: $\quad 36$

4.1.2 Governmental policies and Financial opportunities $\quad 39$

$\begin{array}{lr}\text { Products \& Services. } & 39\end{array}$ 
$\begin{array}{lr}\text { Rural Financing } & 40\end{array}$

$\begin{array}{lr}\text { FIRA Guarantee } & 40\end{array}$

$\begin{array}{lr}\text { Structured Financing } & 40\end{array}$

$\begin{array}{lr}\text { Special programs } & 41\end{array}$

$\begin{array}{lr}\text { Technologic subsidies } & 41\end{array}$

$\begin{array}{lr}\text { 4.1.2.1 LP MODEL } & 41\end{array}$

4.1.2.2 Production Cost, total revenues and profits. $\quad 44$

4.1.2.3 Decision-support tool for small producers to facilitate producer-level decision making. 48

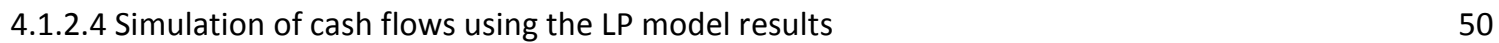

$\begin{array}{lr}\text { CHAPTER V } & 62\end{array}$

5. SUMMARY AND CONCLUSIONS $\quad 62$

$\begin{array}{lr}\text { Summary } & 62\end{array}$

5.1.1 Production and Market Assessment: $\quad 62$

5.1.2 Governmental policies and Financial opportunities 63

$\begin{array}{lr}\text { Conclusions } & 63\end{array}$

$\begin{array}{ll}5.2 \text { Limitations and Suggestions for Further Study } & 66\end{array}$

$\begin{array}{lr}\text { 5.3 Recommendations. } & 66\end{array}$

5.2.1 Trading: $\quad 66$

$\begin{array}{ll}\text { 5.2.2 Government policies: } & 67\end{array}$

$\begin{array}{lr}5.3 \text { Bibliography } & 68\end{array}$

$\begin{array}{lr}\text { APPENDICES } & \mathbf{7 0}\end{array}$

$\begin{array}{lr}\text { Appendix A } & 70\end{array}$

$\begin{array}{ll}\text { Complete Results for the LP model } & 70\end{array}$

$\begin{array}{ll}\text { Appendix B } & 76\end{array}$ 
Appendix C

Plan for different month Fixed-Interest-Rate Loan in the spread sheet developed

Appendix D

Greenhouse Construction Structural typology of greenhouses in Mexico

Greenhouse Construction

Greenhouse purpose

Greenhouse ventilation

Disadvantages are:

Chapel

Advantages of these greenhouses are:

Some disadvantages are:

Double chapel

Saw-tooth roof 101

Appendix E

Application for Permit to Import Plants or Plant Products in USA 


\section{List of tables}

TABLE 1. TOMATO PRODUCTION IN 3 DIFFERENT SYSTEMS (DOMINGUEZ 1999)

TABLE 2. GREENHOUSE INVESTMENT AND PRODUCTION OF VEGETABLES IN 2003 FOR VARIOUS MEXICAN

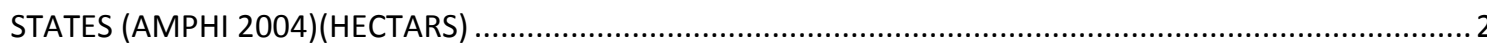

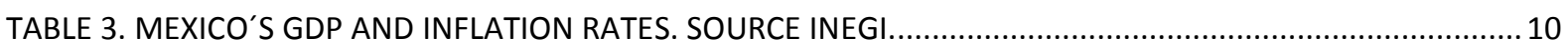

TABLE 4. SOURCE: SOCIETY OF AMERICAN FLORISTS (SAF) STANDARDS FOR CARNATION GRADES ..................16

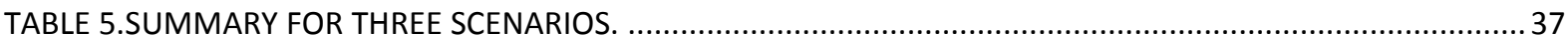

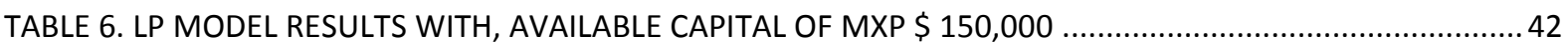

TABLE 7. SENSITIVITY ANALYSIS FOR THE LP MODEL WITH, AVAILABLE CAPITAL OF $\$ 100,000$ MP .................43

TABLE 8.SENSITIVITY ANALYSIS FOR THE LP MODEL INCREASING THE AVAILABLE CAPITAL TO \$300,000 MP ....44

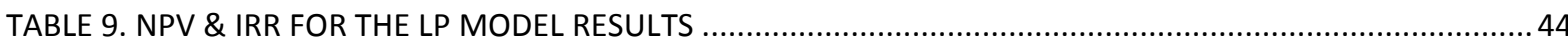

TABLE 10. OPTIMISTIC SCENARIO, SUMMARY OF SALES QUANTITY, PRODUCTION COSTS, TOTAL REVENUES

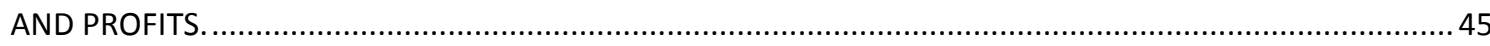

TABLE 11. MOST LIKELY SCENARIO, SUMMARY OF SALES QUANTITY, PRODUCTION COSTS, TOTAL REVENUES AND PROFITS

TABLE 12. PESSIMISTIC SCENARIO, SUMMARY OF SALES QUANTITY, PRODUCTION COSTS, TOTAL REVENUES

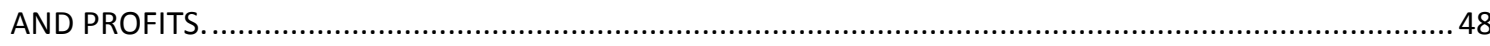

TABLE 13. MEXICAN PARTICIPATION IN US MARKET FOR SOME AGRICULTURAL PRODUCTS. 61

\section{List of Figures.}

FIGURE 1. MAP OF MEXICO

FIGURE 2. DEPTH AND VOLUME OF WATER EXTRACTION IN QUERÉTARO (DOMÍNGUEZ ET AL 1999) 19

FIGURE 3. GREENHOUSE AREA IN MEXICO (AMPHI MEXICAN GREENHOUSE ASSOCIATION, 2004) 20

FIGURE 4. GREENHOUSE AREA IN LATIN-AMERICA (AMPHI MEXICAN GREENHOUSE ASSOCIATION, 2004) 20

$\begin{array}{ll}\text { FIGURE 5. NPV,IRR \& BEP SUMMARY } & 37\end{array}$

FIGURE 6. RE-PAYMENT PLAN FOR A 14-MONTH FIXED-INTEREST-RATE LOAN 49

\begin{tabular}{l} 
FIGURE 7. PART 1 PESSIMISTIC SCENARIO \\
\hline
\end{tabular}

FIGURE 8. PART 2 MODERATE SCENARIO $\quad 52$

FIGURE 9. PART 3 OPTIMISTIC SCENARIO $\quad 53$ 
FIGURE 10. SIMULATION WITH SUBSIDY PART 1

FIGURE 11. SIMULATION WITH SUBSIDY PART2

FIGURE 12. SIMULATION WITH SUBSIDY PART 3

FIGURE 13. U.S. GRADING STANDARDS FOR CALIFORNIA TOMATOES

FIGURE 14. HAND-PACK TOMATO COUNT PER BOX

FIGURE 15.TOMATOES PICTURE FROM UAQ.

FIGURE 16. OPPORTUNITY MARKET FOR SOME EXPORTED PRODUCTS.

\section{Abbreviations}

AMPHI.- Asociacion Mexicana de Productores de Hortalizas en Invernadero

INEGI.- Instituto Nacional de Estadísticas, Geografía e Informática.( Mexican Institute of Statistics and Geography)

MXP.- Mexican Pesos

Sqm.- Square meter

UAQ.- Universidad Autonoma de Queretaro. Autonomous University of Queretaro, Mexico. 


\section{CHAPTER I}

\subsection{INTRODUCTION}

Technological improvement and economic development are the main vehicles for driving growth in Mexico. Therefore, it is necessary to emphasize those areas that are important factors for development, such as electricity and efficient water infrastructure, as well as the efficient use of natural resources.

Sixty percent of Mexico's land is semi arid. As a result, greenhouse production has been growing in recent years. There are opportunities for target products including fruits, medicinal plants, flowers, fish and vegetables.(INEGI)

The advantages of greenhouse production vs open field production are shown in table 1 .

Table 1. Tomato Production in 3 different systems (Dominguez 1999)

\begin{tabular}{|c|c|c|c|}
\hline System & $\begin{array}{l}\text { Water Consumption } \\
\text { Liters } / \mathrm{m}^{2}\end{array}$ & $\begin{array}{l}\text { Performance } \\
\mathrm{kg} / \mathrm{m}^{2}\end{array}$ & $\begin{array}{l}\text { Performance } \\
\text { Liters/kg }\end{array}$ \\
\hline Open Field & 624 & 7 & 89 \\
\hline $\begin{array}{l}\text { Open Hydroponic } \text { system } \\
\text { greenhouse }\end{array}$ & 1,200 & 25 & 48 \\
\hline $\begin{array}{l}\text { Closed Hidroponic } \text { System } \\
\text { Greenhouse }\end{array}$ & 1000 & 50 & 20 \\
\hline
\end{tabular}

Another advantage of greenhouse production is the creation of employment opportunities, especially in rural areas. In Mexico the traditional approach for farm-based labor is to plant crops, go to the USA in search of work, and to come back only at harvest time. While the traditional approach generates only seasonal jobs, production in greenhouses generates permanent jobs as farmers can produce crops year round. 
In addition, the productivity per square meter in greenhouses is higher than the productivity in open fields because resources such as water and labor can be used more efficiently and more advanced technology tends to be used in greenhouses. However, there is room for productivity growth in Mexico. For example, in 1995 Mexico produced 1.5 million tons of tomatoes on 80,000 hectares of land; the same crop was produced on only 2000 hectares in the Netherlands. (LEI-DLO, 1996).

\subsubsection{Greenhouse Technology}

There are many different greenhouse companies operating in Mexico from countries including Spain, Israel, and France. Greenhouse technology was initially developed for colder climates; for example, greenhouses in the Netherlands are designed to support heavy loads from snow. Those greenhouses are also designed to permit maximum light penetration and avoid heat loss. By contrast, in some states of Mexico, greenhouse design should be such that light transmission is reduced so that the temperature inside will be lower than outside.

\subsubsection{Marketing Feasibility}

Greenhouse crop production has been growing in recent years; from 1994 to 2004, land under greenhouse production has increased more than 3000 acres (AMPHI 2004).

This is equivalent to about a $50 \%$ annual growth rate. Each year the investment in greenhouses has also been increasing (See Table 2).

Table 2. Greenhouse Investment and Production of Vegetables in 2003 for various Mexican States (AMPHI 2004)(Hectars)

\begin{tabular}{|l|c|c|c|c|}
\hline STATE & EXISTING 1999 & $\begin{array}{c}\text { UNDER } \\
\text { CONSTRUCTION } \\
1999\end{array}$ & EXISTING 2004 & $\begin{array}{c}\text { UNDER } \\
\text { CONSTRUCTION } \\
2004\end{array}$ \\
\hline BCN & 56 & 38 & 583 & 80 \\
\hline BCS & 106 & 70 & 106 & 70 \\
\hline COAHUILA & 6.0 & 0.0 & 6.0 & 0 \\
\hline
\end{tabular}




\begin{tabular}{|l|l|l|l|l|}
\hline COLIMA & 0 & 70 & 0.0 & 70 \\
\hline CHIHUAHUA & 0 & 20 & 43 & 10 \\
\hline GUANAJUATO & 3 & 20 & 52 & 24 \\
\hline JALISCO & 162 & 30 & 427 & 97 \\
\hline MÉXICO & 0.8 & 0 & 0.8 & 0.0 \\
\hline MORELOS & 16 & 0 & 78.5 & 73.5 \\
\hline QUERETARO & 21 & 0 & 52 & 17 \\
\hline SAN & 0 & 70 & 110 & 12 \\
\hline POTOSÍ & 169 & 30.0 & 504 & 117 \\
\hline SINALOA & 44 & 11 & 209 & 33 \\
\hline SONORA & 22 & 10 & 22 & 10 \\
\hline VERACRUZ & 35 & 0 & 71 & 47 \\
\hline YUCATÁN & 0 & 0 & 41 & 30 \\
\hline ZACATECAS & 641 & 370 & 2306 & 691 \\
\hline TOTAL & & & & \\
\hline
\end{tabular}

This growth causes some marketing-related problems for greenhouse products because these often higher quality products are more expensive to produce (compared to open field products), therefore requiring a price premium for producers together with some degree of market development. Existing market outlets through intermediaries (e.g. Central de Abastos) often mean low market prices for farmers.

This research will focus primarily on the production, financial and market feasibility for greenhouse products for small producers in Queretaro, a semi-arid area of Mexico. The results should be useful to existing producers as well as potential producers considering starting a greenhouse business. In addition, the results should assist producers and policy makers in the development of markets and marketing strategies for this area and areas with similar resource endowments which, in turn, could stimulate rural economic development. 
This thesis is part of the overall research project "WVU-Queretaro Partnership for Greenhouse Technology for Rural Semiarid Regions of Mexico" initiated by the Universidad Autonoma de Queretaro and West Virginia University, funded by Higher Education for Development (HED) a branch of the United States Agency for International Development (USAID). The main objective was to increase productivity and living standards of small-scale farmers, through the development, implementation and transfer of greenhouse technology in the rural semiarid region of "Bajio" States in Mexico.

The next few sections are devoted to a brief description of the research problem, the geography and demographics of Mexico, and the Mexican and local (study area) economies in order to put the analysis and results on this thesis into proper perspective.

\subsubsection{Production area}

In the production area it is important to analyze and forecast what kind of products can be produced in the greenhouses. In addition, it is important to also evaluate the optimal product mix and examine windows of opportunity in the target market. Finally, there is a need to create value-added products and assess direct marketing opportunities.

\subsubsection{Geography of Mexico}

Mexico is the world's eighth largest nation, covering nearly 770000 square miles (2 million square $\mathrm{km}$ ). It is divided politically into 31 States and 1 federal district. Mexican schoolchildren refer to the Mexican map as a "cornucopia" because of its shape, wide at the top at its border with the U.S. (1947 miles long), then narrowing and curving to the East, with its narrowest point at the Isthmus of Tehuantepec, where the Gulf of Mexico and the Pacific Ocean are separated by only 125 miles of land(Figure 1). The land then widens out again, forming the Yucatan Peninsula. Mexico is bordered by Guatemala and Belize to the South East.(INEGI,2007) 


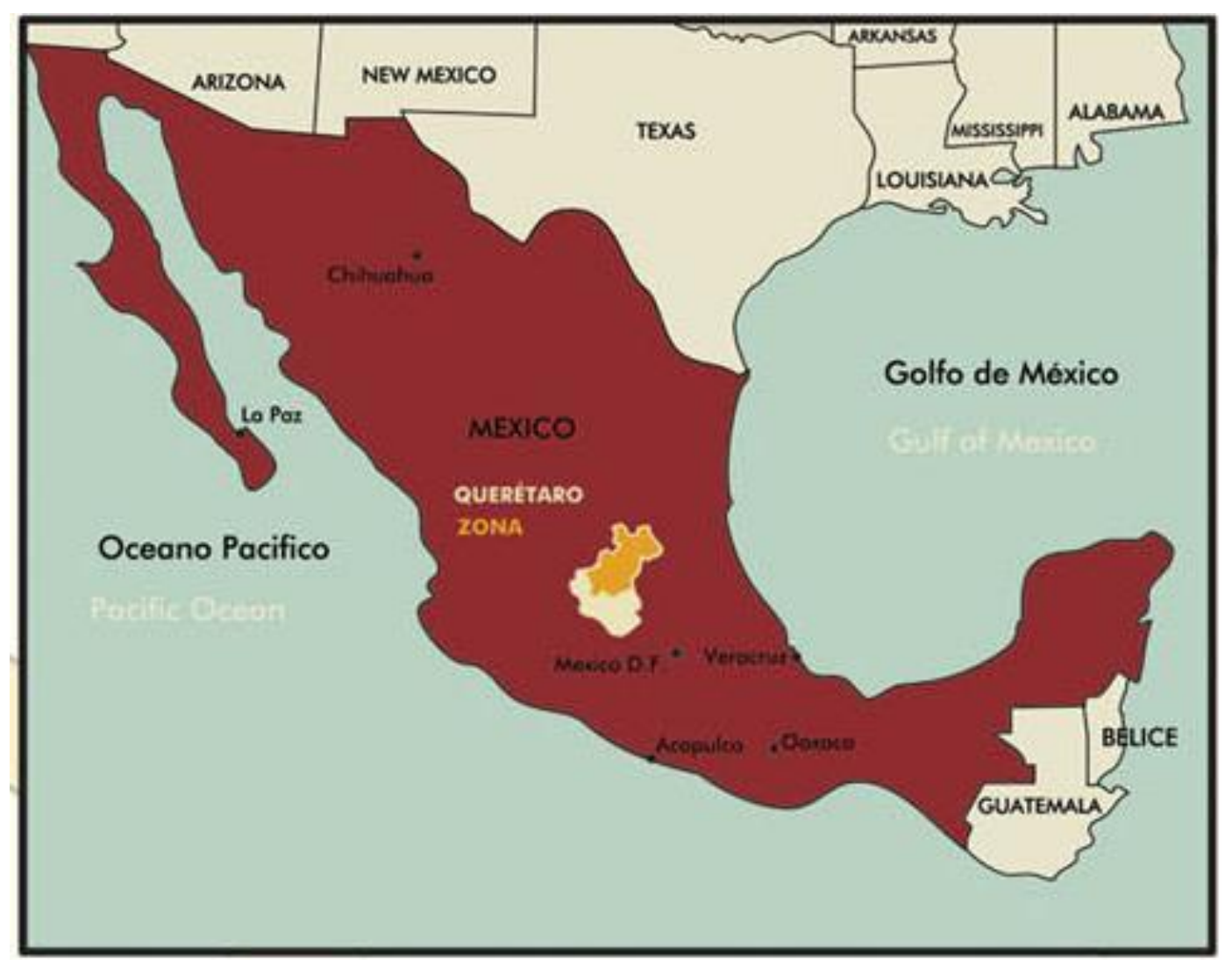

Figure 1. Map of Mexico

\subsubsection{Borders.}

Mexico has borders with the United States of America, Guatemala and Belize, totaling 4,301 kilometers distributed as follows:

- The frontier with the United States of America, from Monument 258 in the northeast of Tijuana to the mouth of the Rio Grande in the Gulf of Mexico, is 3,152 km long. Border States in the north of the country include Baja California, Sonora, Chihuahua, Coahuila and Nuevo León.

- Mexico shares a 956-km border with Guatemala and a 193-km frontier with Guatemala (excluding the 85,266-km maritime border in Chetumal Bay. The border states in the south and southeast of the country are: Chiapas, Tabasco, Campeche and Quintana Roo. 


\subsubsection{Population.}

Mexico has a population of $97,483,412$ inhabitants, according to the most recent census by the Instituto Nacional de Estadísticas, Geografía e Informática (2000), with an ethnic composition of $60 \%$ mestizo, 30\% Indian, $9 \%$ European and $1 \%$ other.

The official language of Mexico is Spanish and it has over 66 Indian languages; the local currency is the Mexican peso.

\subsubsection{Mexico's Topography}

Mexico's Topography is marked by various mountain ranges:

Sierra Madre Occidental in the West

Sierra Madre Oriental in the East

Cordillera Neovolcánica in the center

There are lowlands along the coasts and in the Yucatan Peninsula and high plateau in the center of the country.

\subsubsection{The economy of Mexico}

Mexico is highly dependent on exports to the U.S., which represent more than a quarter of the country's GDP. The result is that the Mexican economy is strongly linked to the U.S. business cycle, and has suffered from the economic slowdown in the United States. Real GDP grew by $4.8 \%$ in $2006,3.3 \%$ in 2007 , and $1.4 \%$ in 2008 , but government officials expect the economy to contract by up to $5 \%$ in 2009 . (CIA\&INEGI)

Mexico's trade regime is among the most open in the world, with free trade agreements with the U.S., Canada, the EU, and many other countries (44 in total). Since the 1994 devaluation of the peso, successive Mexican governments have aimed to improve the country's macroeconomic fundamentals. Inflation and public sector deficits are under control, while the 
current account balance and public debt profile have improved. As of October 2008, Moody's, Standard \& Poor's, and Fitch Ratings had all issued investment-grade ratings for Mexico's sovereign debt. (CIA\&INEGI)

\subsubsection{Trade}

Mexico is dependent on trade with the U.S., which bought about $82 \%$ of its exports in 2007 . Top U.S. exports to Mexico from the U.S. include electronic equipment, motor vehicle parts, and chemicals. Top Mexican exports to the U.S. include petroleum, cars, and electronic equipment. There is considerable intra-company trade.

Mexico is an active and constructive member of the World Trade Organization (WTO). It hosted the September 2003 WTO Ministerial Meeting in Cancun. The Mexican Government and many businesses support a Free Trade Area of the Americas.

Trade disputes between the United States and Mexico are generally settled through direct negotiations between the two countries or via WTO or North American Free Trade Agreement (NAFTA) panels. The most significant areas of friction involve agricultural products such as livestock and sweeteners. To address the issues that affect these industries in a manner consistent with the principles of free trade, the United States and Mexico have established technical working groups. (CIA\&INEGI)

\subsubsection{Agriculture}

Only $13 \%$ of Mexico's land area is arable, of which less than 3\% is irrigated. Top revenueproducing crops include corn, tomatoes, sugar cane, dry beans, and avocados. Mexico also generates significant revenue from the production of beef, poultry, pork, and dairy products. In total, agriculture accounted for $3.7 \%$ of GDP in 2008, yet agricultural employment accounted for over $14 \%$ of total employment. Most of the population is employed in the services sector (60\% of total employment).(INEGI, 2009) 
Implementation of NAFTA has opened Mexico's agricultural sector to the forces of globalization and competition, and some farmers have greatly benefited from greater market access. In particular, fruit and vegetable exports from Mexico have increased dramatically in recent years, exceeding $\$ 4$ billion to the United States alone in 2007. However, structural inefficiencies that have existed for decades continue to limit improvements in productivity and living standards for many in the agricultural sector. These inefficiencies include a prevalence of small-scale producers, a lack of infrastructure, inadequate supplies of credit, a communal land structure for many producers, and a large subsistence rural population that is not part of the formal economy. It is estimated that half of Mexico's producers are subsistence farmers and over $60 \%$ produce corn or beans, with the majority of these farmers cultivating five hectares or less, although the number of Mexican farmers is steadily decreasing as they seek greater economic opportunities from off-farm employment.

Mexico subsidizes agricultural production through various support programs, the most notable being the PROCAMPO initiative.

\subsubsection{Manufacturing and Foreign Investment}

The manufacturing sector, which accounts for about $18 \%$ of GDP, grew by $1.5 \%$ in real terms in 2007. Construction grew by $2.6 \%$ in real terms in 2007.(INEGI)

Foreign direct investment (FDI) in Mexico for 2007 was \$ 25 billion, up 22\% over the previous year. The U.S. was once again the largest foreign investor in Mexico, accounting for $40 \%$ (\$9.9 billion FDI from the U.S.) of reported FDI. The economic slowdown in the U.S. in 2008 and 2009 has caused a significant decline in this figure. 


\subsubsection{Oil and Gas}

In 2007 Mexico was the world's eighth-largest crude exporter, and the third-largest supplier of oil to the U.S. Oil and gas revenues provided more than one-third of all Mexican Government revenues.

Mexico's state-owned oil company, PEMEX, holds a constitutionally established monopoly for the exploration, production, transportation, and marketing of the nation's oil. With its primary known oil reserves already in serious decline, Mexico will have to determine in the near future how it wants to harvest its harder-to-exploit probable reserves in order to avoid very difficult economic choices. The Mexican Congress passed energy reform legislation in October 2008 that gives PEMEX more budgetary autonomy and transparency. However, the reforms do not open the petroleum sector to investment and will do little to address declining production. (INEGI,2007)

While private investment in natural gas transportation, distribution, and storage has been permitted, PEMEX remains in sole control of natural gas exploration and production. Despite substantial reserves, Mexico is a net natural gas importer.

\subsubsection{Transportation and Communications}

Mexico's land transportation network is one of the most extensive in Latin America with 357,000 kilometers $(\mathrm{km}$.) of paved roads, including more than 11,000 kilometers of four-lane paved roads. The 26,622 kilometers (16,268 mi.) of government-owned railroads in Mexico have been privatized through the sale of 50-year operating concessions.

Mexico's ports have experienced a boom in investment and traffic following a 1993 law that privatized the port system. Mexico's ports moved nearly 1.7 million containers in 2006 . A number of international airlines serve Mexico, with direct or connecting flights from most major cities in the United States, Canada, Europe, Japan, and Latin America. Most Mexican 
regional capitals and resorts have direct air services to Mexico City or the United States. In 2005, the Government of Mexico agreed to sell Mexicana, one of the two main national airlines, to a private investor, and did the same with Aeromexico in 2007. Airports are semiprivatized with the government still the majority shareholder, but with each regional airport group maintaining operational autonomy. (INEGI,2007)

The telecommunications sector is dominated by TELMEX, the former state-owned monopoly. Several international companies compete in the sector with limited success. The telephone density rate in Mexico (around 19\%) is below average in Latin America. Wireless penetration is much higher, with over 65 million wireless subscribers in the first quarter of 2008, although 31 million of these customers use prepaid cards, and many use their phones to receive calls only. Mexico's satellite service sector was opened to competition, including limited foreign direct investment, in 2001.

Mexico`s GDP is as follow: GDP (official exchange rate, 2008 est.): $\$ 1.143$ trillion.

GDP (PPP method, 2008 est.): \$1.559 trillion and per capita GDP (PPP method, 2008 est.): $\$ 14,200$. The annual GDP growth rate and inflation rates are shown in table 3 .

Table 3. Mexico's GDP and inflation rates. Source INEGI.

\begin{tabular}{|c|r|r|r|r|r|r|r|r|r|}
\hline & $\mathbf{2 0 0 8}$ & $\mathbf{2 0 0 7}$ & $\mathbf{2 0 0 6}$ & $\mathbf{2 0 0 5}$ & $\mathbf{2 0 0 4}$ & $\mathbf{2 0 0 3}$ & $\mathbf{2 0 0 2}$ & $\mathbf{2 0 0 1}$ & $\mathbf{2 0 0 0}$ \\
\hline $\begin{array}{c}\text { Annual real GDP } \\
\text { growth }\end{array}$ & $1.4 \%$ & $3.3 \%$ & $4.8 \%$ & $3.0 \%$ & $4.4 \%$ & $130.0 \%$ & $0.8 \%$ & $0.2 \%$ & $6.6 \%$ \\
\hline Inflation rate & $6.2 \%$ & $3.8 \%$ & $3.4 \%$ & $3.3 \%$ & $5.2 \%$ & $4.0 \%$ & $5.7 \%$ & $4.4 \%$ & $9.0 \%$ \\
\hline
\end{tabular}

Natural resources include petroleum, silver, copper, gold, lead, zinc, natural gas, timber.

Agriculture accounts for $3.7 \%$ of GDP. Main products include corn, wheat, soybeans, rice, beans, cotton, coffee, fruit, tomatoes, beef, poultry, dairy products, wood products. 
Industry accounts for $34.1 \%$ of GDP Types of industries include food and beverages, tobacco, chemicals, iron and steel, petroleum, mining, textiles, clothing, motor vehicles, consumer durables.

The service sector accounts for $62.2 \%$ of GDP. Main service sectors include commerce and tourism, financial services,

\subsection{RESEARCH PROBLEM}

Given the scarcity of water, land, labor and other resources, we step out to investigate whether or not greenhouse products represent a feasible alternative for small producers compared to open-field production. Using a combination of enterprise budgeting, capital investment analysis and optimization, we found that under most of the conditions investigated the six different crops analyzed were profitable. At the same time, greenhouse production has the advantage of conserving scarce land and water resources, and potentially reducing production and market risk. Simultaneously, they, offer consumers healthful products of good quality that can also contribute to the development of the local economy. One problem is that greenhouses often involve a larger up-front investment, and that access to borrowed capital is often difficult. Next, some background on the greenhouse industry is presented to put the research problem into perspective.

\subsection{Background}

\subsubsection{Origin of the Greenhouse Industry}

The greenhouse industry as we know it today probably originated under circumstances similar to those that existed in Holland during its "Golden Age", the 1600s, when The Netherlands became the world's foremost sea power. Its merchant fleet tripled to the point where The Netherlands provided half the world's shipping, and Amsterdam was the world's 
leading commercial city. The Dutch standard of living was the highest in the world. The royal courts of Europe at this time had a taste for elegance and the means to afford it. Spring flowers in the winter and fruit out of season were very attractive. And soon the largest greenhouse industry in the world was born. Grapes were grown along rock walls in western Holland under glass enclosures constructed in a lean-to fashion. These greenhouses conserved the energy of the sun during the winter and permitted early crops of grapes. Today, a vast green-house vegetable and cut-flower industry exists, with its centre in the Westland area, as a direct descendant of this initial business.

In the region near Amsterdam, field-grown lilac bushes were dug in late fall, prior to the freezing of the ground and were stored outside. Periodically during the winter, bushes were moved into greenhouses where they broke dormancy and flowered. The cut blooms graced the palaces of $17^{\text {th }}$-century royalty in Great Britain, France, Germany, and other countries. Even today this industry persists, although much of this region, near Aalsmeer, is involved in pot-plant culture in general. Today, The Netherlands is the largest producer of floral products in the world, producing almost 25 of the total value. Greenhouse development in North America followed much later and it was brought by immigrants from Europe and the industry began to establish in the $19^{\text {th }}$ century. The first reported greenhouse in the United States was that of James Beckman in 1764 in New York City (Kaplan 1976.) The floriculture industry stated in Boston, New York, Philadelphia, and, later, Chicago. The modes of transportation of those days required close proximity to the markets. (Nelson 1998,pgs 2-3)

\subsubsection{Fresh flowers}

Through the end of the $19^{\text {th }}$ century, floral products were transported by horse-drawn wagons and the transportation was limited to local areas. The development of truck transportation in the early $20^{\text {th }}$ century changed that and made it possible to transport greater distances without undue damage to the product and it make possible for the first time to produce in a remote 
area and distribute to other places. Three facts govern the suitability of a given production area: production cost, quality and transportation cost.

As trucks became commonplace in the early part of the $20^{\text {th }}$ century, transportation posed less of a problem. The populated areas of eastern Massachusetts, Connecticut, and New York City, Philadelphia and Chicago became major centers for flower production. From these centers, fresh flowers were transported considerable distances to smaller towns. This early centralization was probably driven by an information infrastructure. These areas had a critical mass of growers and allied supply industry to share technical information, to foster new innovations of efficiency, and to create the wholesale distribution channels needed. All of these factors led to lower production costs. When air and refrigerated-truck transportation was developed, it made economically feasible shipping flowers to any point. The growing of products outdoors in warm climates for shipment to distant markets became a possibility. All the developments in transportation and conservation spread the production areas to the south and to the west coast to Florida, Colorado and California. (Nelson 1998)

In 1969, an intercontinental shift became apparent. Actually the story began in 1966, when to carnation ranges in Bogotá, Colombia, began producing quality carnations at and incredibly low price. They were joined in 1969 by a U.S. firm, and others quickly followed. Today, the majority of fresh flowers consumed in the United States come from Colombia. The area offers high light intensity because of its high altitude. These factors are ideal for high-quality carnation production. Additionally, the cost of labor is low, and there is no expense fore heating because flowers are produced in unheated plastic houses in Colombia.

Rose imports became significant during the late 1970s. The level of imports has grown continuously since then, and in 1995 constituted 66 percent of roses sold in the United States. Rose imports lagged behind carnation and chrysanthemum imports because roses have a short 
shelf life and are more susceptible to mishandling. Roses require more sophisticated production and marketing. The Latin American industry, in the early stage of development, found it difficult to address these needs. However, this was a temporary obstacle, as the growing conditions in countries such as Colombia are conducive to quality production. Sizable quantities of roses began to be imported from Colombia, followed more recently by Ecuador, Guatemala and Mexico. Roses from Ecuador are rapidly gaining worldwide acceptance due to their exceptional size and quality.( Nelson 1998)

Flower imports originate primarily from parts of the world along established trade routes. The Middle East and Africa are the likely origins of floral imports into Western Europe because of the established trade between these two parts of the world. Similarly, North America and South America are logical trade partners, as are Japan and the other Asian countries. Wellestablished means of transportation exist along each of these routes. The cost of shipping in these channels is inexpensive relative to shipping between parts of the world in different channels. While there are well-esstablished trade channels between Japan and the United States, as well as Europe and the United States, the United States is not the recipient of significant quantities of floral imports from Japan or Europe. The reason is that production and marketing cost do not very enough between these areas to offset the shipping costs. Labor is expensive in both areas and energy inputs are high.( Nelson 1998)

This does not mean that no imports will travel along these channels. There are always niche markets. For instance the United States imports proteas from South Africa, cut bulbs from The Netherlands, and orchids from Thailand because each of these countries has production advantages not yet found in the Latin American countries that are our trading partners. (Nelson 1998,pgs 3-10) 


\subsubsection{Production Opportunities Near Developed Markets}

\subsubsection{Small Growers}

Small growers always have a place in the agricultural industry because there are some niches that can be handled easier by them, such as superior quality, new crop introductions, low volume, specialty crops, and integration of production and retailing.

At a certain point, increases in quality are met with diminishing demand. It is difficult for large production firms to offer ultrahigh quality levels and the small growers are better positioned to meet the smaller demands for high quality.

A period of time is required to develop the full market potential after a new crop is introduced. The demand during this developmental stage is too small to lend itself to high level of automated production required by larger firms. This window of time offers an advantage for small growers because it is often possible to command higher prices than will be possible later when the market is saturated. There are some specialty crops which have a small demand even after the marker potential has been met. Since it is difficult for a large grower to produce large numbers of low-volume crops, these crops are best left to the small growers. Such crops could include bonsai plants, terrarium plants, aquatic plants for fish tanks, plants with unusual fragrances, rare plants for plant collectors, and collections of a given category of plant such as begonia, geranium, or carnivorous plants. (Nelson 1998)

Small growers can also add value to greenhouse products in several ways that would support higher sales prices. Offering people to visit a production greenhouse, a class in floral design, a class in houseplant care, free root substrate, fertilizer solution, services like these can be translated into higher sale prices above the retail market average. (Nelson 1998,pgs 29-31) 


\subsubsection{Grading and Standards}

There is a considerable controversy about grading. Opponents cite factors such as the increased cost of handling. Proponents see grading as a means of discouraging poor quality in the marketplace and achieving financial remuneration for quality. But there exists the problem of diversification of grading systems among growers and even the shifting of standards by an individual grower. If grades could be standardized for all growers, it would be a great benefit for wholesalers and retailers (Flower Marketing Association USA). Ultimately, what benefits the market system and the consumer usually brings benefits to the grower. Standard grading could give both the marketer and the consumer for judging and demanding the quality they are willing to pay for. It would give the grower a tangible objective and measuring stick for achieving a better product. Greater consumer satisfaction should lead to increased product demand. Higher-quality production and handling would help reduce product loss in the market channel, which could be helpful in reducing the final selling price of crops. Obviously, marketers must get involved in this aspect also. Different aspects of the products can be used for grading, volume, diameter, color, ripening, texture, shape, depending on the product. An example of standards for carnation grades is shown in the next table. (Nelson 1998,pgs 564-567)

Table 4. Source: Society of American Florists (SAF) Standards for Carnation Grades

\begin{tabular}{|l|l|l|l|}
\hline & $\begin{array}{l}\text { Blue Grade } \\
\text { (Fancy) }\end{array}$ & $\begin{array}{l}\text { Red Grade } \\
\text { (Standard) }\end{array}$ & $\begin{array}{l}\text { Green Grade } \\
(\text { Short })\end{array}$ \\
\hline Minimum length & 22 in $(56 \mathrm{~cm})$ & 17 in $(43 \mathrm{~cm})$ & 12 in $(30 \mathrm{~cm})$ \\
\hline Minimum flower & Tight-2in $(51 \mathrm{~mm})$ & $13 / 4$ in $(44 \mathrm{~mm})$ & No requirement \\
diameter & Fairly tight-2in $(64 \mathrm{~mm})$ & $21 / 4$ in $(57 \mathrm{~mm})$ & \\
& Open-3 in $(76 \mathrm{~mm})$ & $2 \frac{3}{4}$ in $(70 \mathrm{~mm})$ & \\
\hline
\end{tabular}

\subsubsection{The market system}

There are consumers wherever people live -in cities, towns, and villages scattered throughout the states and provinces. The production however is centralized where the producers are. The heaviest concentration of tomato producers in Mexico is in Sinaloa, Coffee producers are 
concentrated in Veracruz, and flowers in Estado de Mexico, under such circumstances, a complex marketing system is necessary.

The marketing system serves the functions of gathering together the different products of many diverse growers (i.e., it creates "place utility"), bringing these within reach of consumers both close to and distant from the producers, and developing a consumer awareness and desire to purchase the products.

\subsubsection{Advertising}

The need for advertising varies. A grower who sells to one wholesaler or to a few wholesalers will generally have little motivation to advertise, but the grower of a centralized crop probably will be interested in new wholesale outlets.

The retailer has the greatest need for advertising. Unfortunately, cost may be a deterrent. Those who advertise generally find it profitable. Newspaper ads are most commonly used. Radio spots are also valuable, particularly toward the weekend and in connection with a gardening program. Television has been used by some and can have a far-reaching effect when done properly. Mailing lists have provided a very successful avenue of communication with the consuming public for many retailers. The major weight of advertising rests on the retailer but the grower is not without obligation. The allied supply industry -growers, wholesalers, and retailers- are all parts of one system that culminates in the sale of products to the consumer. It has been demonstrated in the advertising effectively increases the demand for these products. This ultimately benefits all segments of the industry; thus, all should share in the advertising program. Shared advertising is often practiced in other businesses. The Coca-Cola sign, so often used to display the name of a restaurant, is paid for in part by The Coca Cola. Advertisements for a given product, regardless of the retail out-let, will carry the same logo (sketch, picture, and so on). The logo is developed and provided at the expense of 
the producers. The advertising cost for many items presented by the local supermarket in its newspaper ads is borne by the producer of the products (Berninger,1982). There are several things producers can do:

1. Financially support cooperative advertising programs.

2. If it is possible and warranted, work with wholesalers and retailers in local promotional programs.

3. Establish communications with the wholesale and retail segments of the industry.

\section{Greenhouse growth in Mexico and Latin America}

As can be observed in Table 1, one of the solutions to the water problem in Mexico is greenhouse production. According to CAN (Comisión Nacional del Agua) 80\% of water consumption in Mexico is for agricultural activities, that is why an efficient use of water is vital. An automated production system under greenhouse requires only 20 liters of water to produce one kilo of tomato, on the other side 89 liters are required to grow the same quantity of tomato in an open field greenhouse. As can be seen from this illustration, $400 \%$ of water is saved.(AMPHI,2004)

In general, $70 \%$ of the agricultural production in Mexico is located in Tropical, Arid Subtropical or Semiarid weather. In those conditions the water availability each time is more restricted because of the growing population as well as the insufficient aquifer reload. As an example, in the "Bajio" it was possible in the sixties to find in many places water just one meter underground, nowadays in the best case water is found $200 \mathrm{~m}$ underground. On the other hand, in April 2004 water reservoirs were only filled at 35\% of its capacity. (CEA, Mexican Water Institute,1999) 


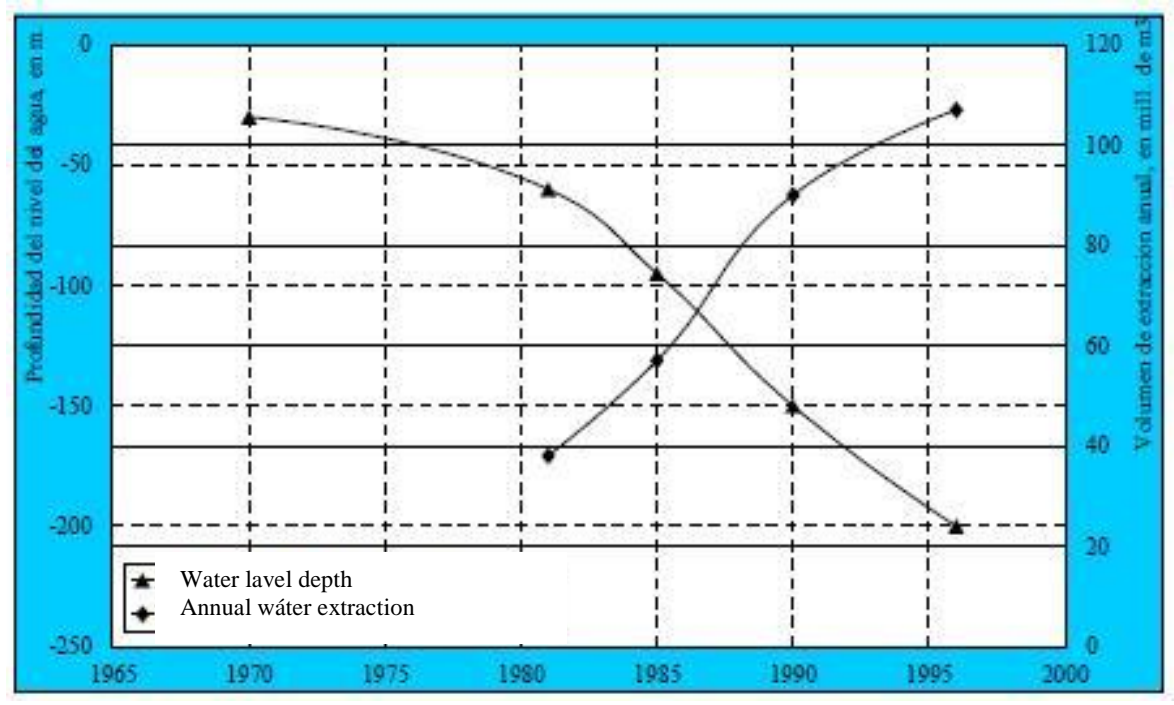

Figure 2. Depth and volume of water extraction in Querétaro (Domínguez et al 1999)

The water use for crop irrigation is reflected in higher and higher marginal costs. It is estimated that in agricultural production $40 \%$ of water used in irrigation is wasted.(CEA Queretaro Water Institute,1999) There are more critical cases, for example, in Guanajuato 416.25 million $\mathrm{m} 3$ of water is extracted from the aquifers but is estimated that only 121.86 millions of $\mathrm{m} 3$ are required. In this case the inefficiency is more than $150 \%$ at plot level and almost $250 \%$ in the entire process. Figure 2 shows The water level depth and the annual water extraction.

From 1999 to 2004 more than $1600 \mathrm{Ha}$ of greenhouses have been installed in Mexico (AMPHI 2004), meaning a 50\% of annual average growing in new investments, every year this percentage rises. In 2004, investments in the State of Queretaro totaled 13 million pesos and amounted to $17 \mathrm{Ha}$ of greenhouses in 2008 , of an agro park project of more than $300 \mathrm{Ha}$ of greenhouses was initiated. 


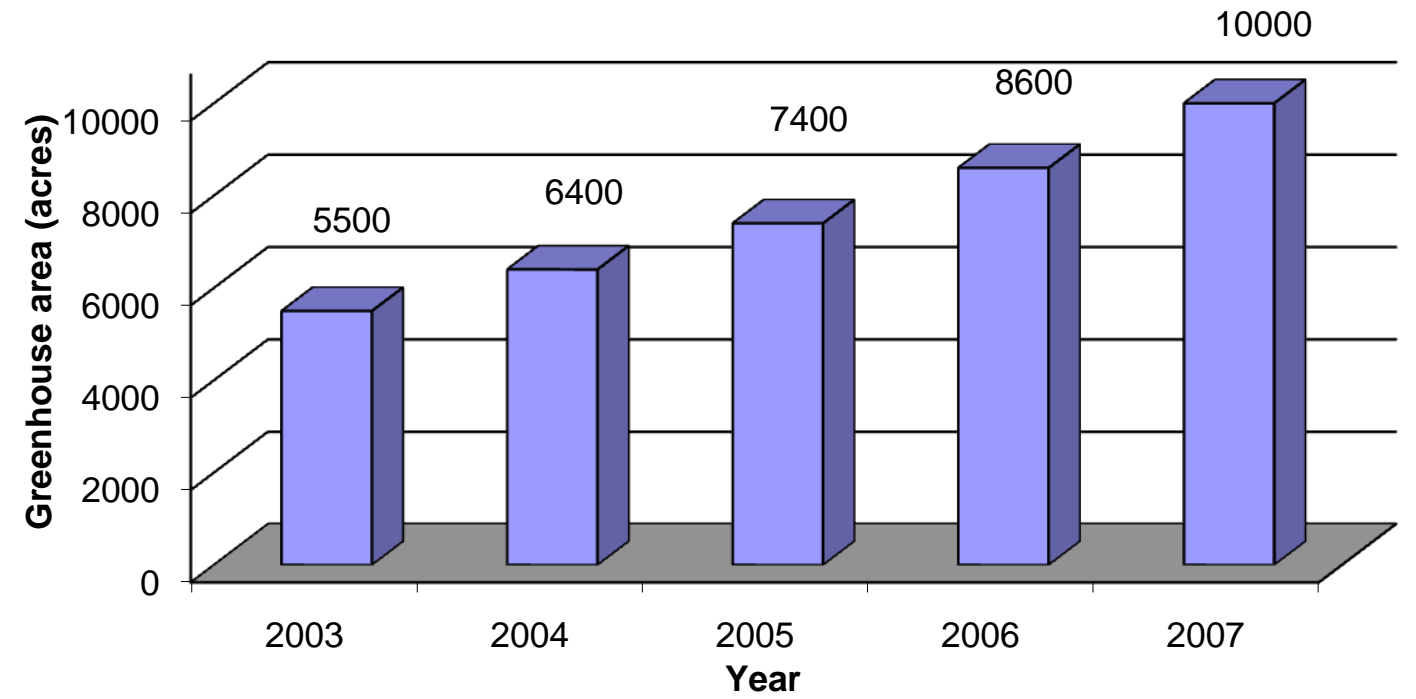

Figure 3. Greenhouse Area in Mexico (AMPHI Mexican Greenhouse Association, 2004)

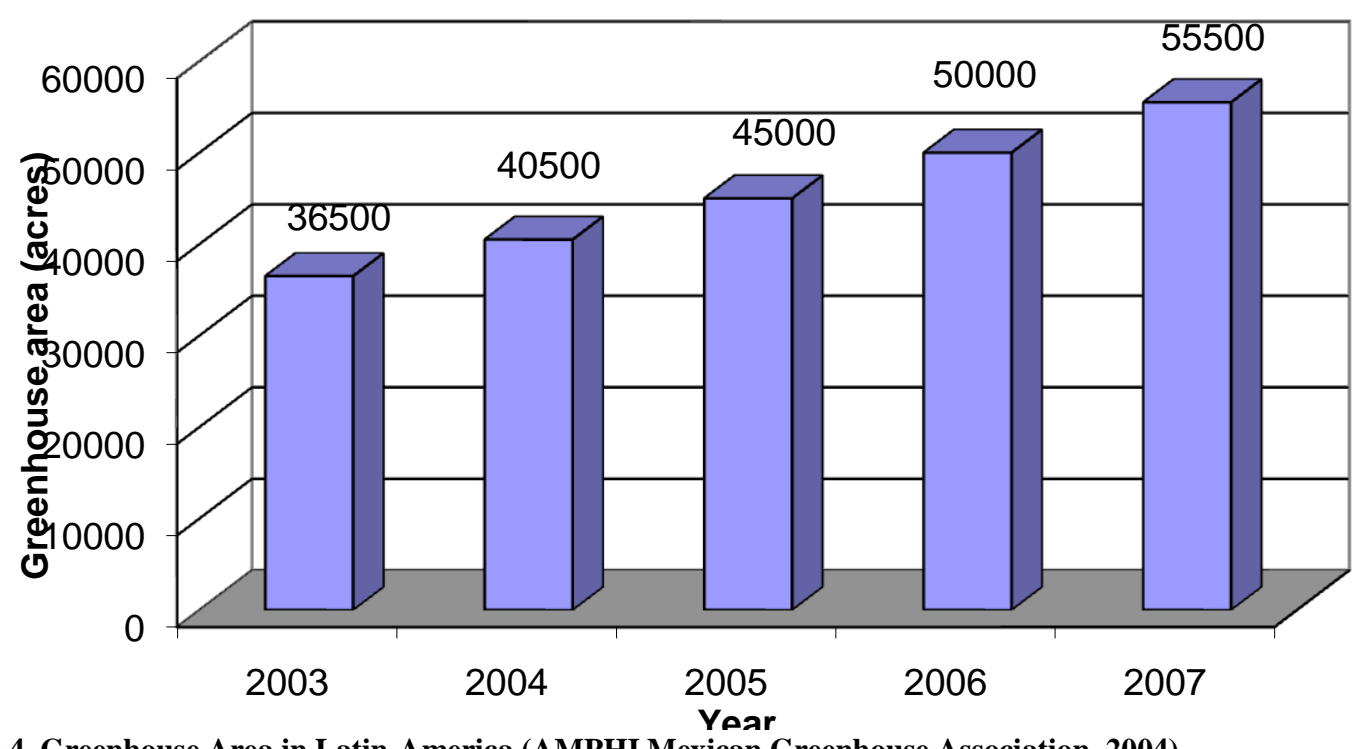

Figure 4. Greenhouse Area in Latin-America (AMPHI Mexican Greenhouse Association, 2004)

\subsection{OBJECTIVES}

One of the big agriculture-related problems in Mexico nowadays is to identify alternatives for small producers that allow the creation of a competitive and profitable product, but that also offers consumers healthful products of good quality, and can contribute to the development of the local economy. 
For this reason I propose a study of alternatives of controlled environment production under greenhouses, for small producers in the state of Querétaro in Mexico.

I propose three areas of investigation:

1) To conduct a production, financial and market assessment

2) To analyze governmental policies in Mexico and the USA, especially with respect to exports.

3) To evaluate credit programs for small producers. 


\section{CHAPTER II}

\subsection{REVIEW OF LITERATURE}

There are several studies that show the market feasibility for greenhouses products.

Oliphanr (undated) mentions in his paper some important aspects about greenhouses production such as (pg 2-10):

1) Design and build low-input greenhouses and offer workshops that would

encourage entry into greenhouse production by minimizing capital expenditures.

2) Produce an instruction booklet on building a low-input greenhouse.

3) Develop a small scale CSA model utilizing produce from these greenhouses and

conduct initial market tests.

4) Train a construction crew that is capable of commercial construction of low input,

energy efficient greenhouses.

The author analyzed some value-added organic products and compared the expenditures involved in different types of greenhouse production. This study also addressed greenhouse history, production costs and consumer demand for directly-marketed organic products.

This was followed by a modest market survey with $40 \%$ of the respondents indicating that organically grown produce was important to them, although they were unwilling to pay more than a $10 \%$ premium for the product. This information can help in the evaluation of some consumption trends for greenhouse products. 
Engindeniz (2002) presents results for greenhouse production in the context of sustainable agricultural production. The author analyzes the initial investment and production costs for greenhouses in Turkey.

Thomas (2008) states that there are important elements that need to be considered in order to have more alternatives for greenhouses products. These range from growth characteristics of the crop, to volume/space/time relationships of crops, pest control methods, as well as many others. In addition to these, Thomas also states that it is of critical importance that any alternative crop decision must be based on sound technical knowledge gathered from a variety of sources. Although this can be obtained from a variety of sources, Thomas indicates that, most importantly, it should be from those with knowledge of the growers region and situation.

Weseen,(2001) discusses the history of greenhouse production where, initially greenhouses are associated with cool climates, areas where it is necessary to maintain minimum heat requirements for plant growth or for the extension of the growing season. Greenhouses can also serve as a microclimate for cooling when temperatures are too high (Hanan, 1998). Developed and less developed nations rely on greenhouse production both for domestic consumption and for export to varying degrees. More labor-intensive greenhouse operations tend to be utilized in less developed countries, which can serve as a substantial source of employment. In addition, Weseen discusses the importance of utilizing waste heat (unused heat captured from a source in the atmosphere and then distributed for use in a greenhouse operation) as a valuable input in greenhouse operations. The author states that this waste heat would considerably reduce operating and production costs, which could result in economic benefits for the producer. 
In the exploration of greenhouse production, especially in Latin American countries, it is import to consider it as a development issue. Given this, Gilherme Ary Plonski (2000) analyzes innovation and cooperation, discussing a popular and well-developed method of development in Latin American countries. This method, known as the Innovation Triangle, or "Sabato's Triangle", takes the approach that to have adequate development strategies in Latin America, there must be cooperation between governments, universities, and industry. The author illustrates several examples in several different industries, which means that the Sabato triangle could be extrapolated to Greenhouse industries.

Cabrera, Baker and Hildebrand (undated) conducted a study about ways of improving the Cañete small farmer community in Florida through agricultural extension. Asparagus and grapes are two introduced crops in the Cañete Valley. They are perceived as complex but profitable. Currently, the development agencies are recommending these crops for the small farmers as alternatives to improve their livelihood. Indeed, development agencies are financing these crops. The six-year model was used to test the viability of these alternatives from the small farmer perspectives. The authors use a six year optimization model to test the viability of alternative crops like asparagus and grapes from the small farmer perspective. In the case of asparagus, the development agency requires that small farmers be able to plant at least one hectare due to harvesting and marketing concerns. Farmers need to analyze marketing elements to make wiser decisions in order to obtain higher incomes.

A linear cropping model was developed by Hassan, Ahmad, Akhter to determine the optimum cropping pattern in Pakistan. In the study irrigated areas of Punjab province were selected for determining the optimum cropping pattern under various price options. An LP (linear programming) model was applied to calculate the optimal crop acreage, production and income of the irrigated Punjab. This study was based on this LP model. 
A market feasibility study for agricultural incubator (a facility designed to foster entrepreneurship and help startup companies to grow through the use of shared resources, management expertise, and intellectual capital) in Southern Maine (2005) was undertaken to ascertain the market demand, market opportunities such as local agriculture, specialty foods, organic, ethnic foods, floral and nursery crops. The study also reviewed the market supply chain including existing agriculture support agencies, programs, and services, and various incubator models (incubator without walls, single purpose facility, multi-puropose facility). The results were mixed. Prospective producers and processors have vastly different needs from more established ones. Established enterprises hold fixed assets - land base and/or production capacity. Innovation requires access to capital to maximize these assets. Prospective entrepreneurs, on the other hand, are more mobile and more likely to take advantage of space in a shared facility.

Still, each enterprise needs to "move" product. For entrepreneurs who set up shop in an incubator, they will naturally want to maximize their time and resources by taking advantage of on-site facilities. Established producers also require assistance plus an avenue through which value can be added to product that they can not "move" through their own direct marketing and wholesale activities. Direct marketing, business planning, access to capital, and peer networking can take place within or outside of a "bricks and mortar" facility.

Established enterprises hold fixed assets - land base and/or production capacity. Innovation requires access to capital to maximize these assets. Prospective entrepreneurs, on the other hand, are more mobile and more likely to take advantage of space in a shared facility. Still, each enterprise needs to "move" product. For entrepreneurs who set up shop in an incubator, they will naturally want to maximize their time and resources by taking advantage of on-site facilities. Established producers also require assistance plus an avenue through which value can be added to products that they can not "move" through their own direct marketing and wholesale activities. 
Direct marketing, business planning, access to capital, and peer networking can take place within or outside a "bricks and mortar" facility.

The New York greenhouse business summary and financial analysis by Fei-Uva and Richards features annual financial and marketing benchmarks for the New York greenhouse industry. It includes the development of balance sheets financial ratio analysis, income statements, measures of profitability, cash flow statement analyses, analyses of capital, operating and labor efficiency and industry benchmark analyses of selected business factors.

The analysis also evaluates the marketing channels are used by New York greenhouse businesses. Direct sales to consumers were the most common marketing method used by New York greenhouse businesses. Seventy-nine percent of greenhouse operations merchandised their products through retail outlets, followed by $39 \%$ selling wholesale to garden centers. Nonetheless, the highest volume of industry sales was from wholesale to mass marketers (45\%), conducted by only $10 \%$ of the operations in the industry. The next highest sales value was generated by wholesale to garden centers $(21 \%)$, followed by retail sales $(13 \%)$.

The government of Mexico has instituted a support program for rural investment projects PAPIR ("Proyectos de apoyo a proyectos de inversión rural"). Included in the program are three types of targeted interventions specifically designed for the poor. The first group promotes investments in the human capital, with a focus on education, health, and nutrition. The second aims to improve employment opportunities for the poor. The third targets poor areas in order to provide them with better services and physical capital.

In a farm-level analysis by (Alford, Griffith and Cacho, 2004) a suite of economic tools including LP modeling is used to assess technologies at the farm level, listing some of the major benefits and limitations of each of these various techniques. A representative farm for the selected farming system is then developed and a whole-farm linear program based on this 
representative farm is described in some detail. A series of modeling experiments is undertaken to examine variations of the base model and their impact on the resulting technology evaluation. A representative farm for the selected farming system is then developed and a whole-farm linear program based on this representative farm is described in some detail. A series of modelling experiments is undertaken to examine variations of the base model and their impact on the resulting technology evaluation. An example technology, involving the genetic improvement of beef cattle for improved feed efficiency (NFE), is evaluated. 


\section{CHAPTER III}

\subsection{METHODOLOGY AND DATA}

A combination of primary and secondary data was used in this study. The primary data were collected from visits to different government agencies, local greenhouses and commercial banks. Secondary data were obtained from the SAGARPA, (Agriculture Department in Mexico from 2008-09), and others government agencies the study was conduced in Queretaro, Mexico. For this study we choose six different crops to get a mix of products in a 2000sq meter greenhouse which is a minimum size to sustain a four member family in rural area in Mexico ${ }^{1}$. The selection of the crops was made based on data from SAGARPA, focusing on products with a growing demand in Mexico and USA markets.

\subsubsection{Primary Data}

To obtain the primary data different government agencies, greenhouses and commercial banks were visited to determine prices, quantities, technical production coefficients(for the enterprise budgets and LP model), and the support and financial programs for small and midsize enterprises (SMEs).

Three different commercial banks were visited during 2008-09: Santander, HSBC and Banamex. Santander does not have any specific programs for agriculture projects, but the office we visited indicated that they occasionally fund greenhouses (including a $30 \mathrm{Ha}$ greenhouse project), but some credit requirements were specified, including that production was already commercialized and that the technology of the greenhouse must be from Spain (Santander, incidentally, is a bank based in Spain).Although HSBC has programs for SMEs they do not have any specific program for agricultural projects. They offer relatively low interest rates, however, as they view agriculture projects as risky, they tend not to fund such

\footnotetext{
${ }^{1}$ Source: Quevedo, E. Queretaro State University Unpublished work
} 
projects. Banamex recently added programs for SMEs and they have contemplated opening some programs for rural areas. Another bank of the area, BB (Banco del Bajio) has programs specially designed for producers and traders in the field; it is the leader in financing of productive projects participating directly in government programs for agriculture (PROCAMPO), also financing programs for grains, fruits, vegetables, coffee, cacao and cotton.

Some greenhouses in the state of Queretaro were visited to calibrate the enterprise budgets and LP model. Below is a listing of some of the different greenhouses visited; in order to keep them anonymous, only the location of the greenhouse is included.

\section{Greenhouse in Huimilpan}

This is a greenhouse of a small producer of 1900sqm with primarily -tomato production. It was built with assistance from a local university, UAQ and has been operated for five years and received partial government support.

The grower has had different stages of commercialization of the product, from selling directly to the consumer to making contract with some of the biggest greenhouses of the state. The price they have obtained for tomatoes has been fairly low, ranging from, $\$ 3$ to $\$ 10$ pesos per $\mathrm{Kg}$.

\section{Greenhouse in Colon}

This greenhouse is one of the biggest in the state with more than $20 \mathrm{Ha}$ under production and exports the majority of the product to the United States. Its production is tomato and green pepper. 


\section{Greenhouse in Corregidora}

In this region two different greenhouse were visited. One was 2000sqm for tomato production and one was 1000sqm for frog production. These small producers have commercialized the products that sell to two hotels and small restaurants in the areas. Its good location, just 500m from a highway have enabled them to sell their product to a hotel chain located in the resort area of Cancun. This grower indicated that he has been operating his greenhouse since 2002, facing commercialization problems the first three years. Subsequently, once these problems were solved, the next few years, the operation had technical problems such as broken film covers. The other greenhouse visited has only been in operating for one year, with the producer receiving a 50\% subsidy from a government program. The government committee accepted his application for the subsidy only after he conducted a project analysis and after this analysis was evaluated by a government agency. Being a subsidy, in this kind of program, it is not necessary to return the money to the government. The frog production greenhouse targets, pet stores, food for other predators like snakes and to restaurants for frog legs dish.

\section{Greenhouse in El Marques.}

Two greenhouses were visited in El Marques. The first one belongs to the campus Amazcala of a local university, UAQ, where there are a variety of different enterprises of different sizes such as Tilapia, Tomatoes, Beans, Tomatillos, Corn, Frogs, Green Hidroponic Forage, etc. This is an academic research and demonstration project with the intention of being a sustainable unit, although primarily a research facility, the products have been commercialized directly to the consumer, the local market (Central de Abastos), restaurants and hotels. The project started in 1998, with 1000sqm and now is bigger than $2 \mathrm{Ha}$; the UAQ 
initiated a Department of Design and Building of Greenhouses, following the success of its research facility.

The other greenhouse visited was 1900sqm and it is not operating because the small producer did not have the liquidity to cover the 50 percent equity funds required by the government to receive the support.

\section{Greenhouses in Pedro Escobedo}

Belongs to a Netherlands company, with a sizes of more than $18 \mathrm{Ha}$. It produces different types of tomato, such as Saladet, Cherry, etc. Almost 90 percent of its production is for exportation to the USA.

\section{Greenhouse in Villaguerrero, State of Mexico.}

Greenhouses specializing in flower production were also visited. Some of the producers sell directly to the final consumer in the Market of Jamaica, (the biggest flower market in Mexico City) and others sell the flower to intermediaries who commercialize the product in the same market.

In order to evaluate the objectives for this study, the methodology will be as follows:

\subsubsection{Production and Market Assessment:}

- Standard economic and financial feasibility techniques such as NPV and IRR.

- Evaluation of appropriate technologies for the construction of greenhouses in the study area, and, in the process, to determine the best alternative for the installation of a greenhouse.

- Analysis of the production costs, revenues, and the break-even point using a combination of primary and secondary data. 
- Look at cooperative or similar arrangements so that small producers can obtain better prices from their suppliers.

- Identifying opportunity windows for the target products including fruits, medicinal plants, flowers, fish or vegetables.

\subsubsection{Governmental policies and Economic Feasibility}

- Will include analyzing and monitoring the prices of these products in Mexico and the USA to make the best decisions from a production viewpoint.

- Examining direct marketing strategies appropriate for the study area.

- Identifying export-import requirements for greenhouse products in the US and Mexico.

- Using a linear programming model, to determine optimal product mix, and, subsequently to develop a decision-support tool for small producers to facilitate producer-level decision making.

To trade the greenhouse products in supermarket chains, in this study was identified some institutions or organization, that have exports standards, for example some stores like Wal-Mart buy Mexican products if they are certified with the Mexico Supreme Quality certification (Mexico Calidad Suprema).

(www.mexicocalidadsuprema.com.mx, 2007)

To evaluate the appropriate greenhouse technology, were asked to different greenhouses enterprises being the greenhouses with lower prices those built by the UAQ where different type of structures for the area were developed in the last years.

The objective function for this LP Model was specified to maximize the net profits above variable costs. There were 6 different crops, including 2 vegetables, 2 flowers and 2 fruits. Invoking portfolio theory, the constrains were specified such that at least one of each 
type of crop was in the optimal solution. The model was also subject to different constraints such as the availability of land, water, capital, and labor

For capital, labor, fertilizer and others constraints, they are included in production costs. The empirical model is shown below:

$\operatorname{Max} \mathrm{Z}=\mathrm{P}_{\mathrm{V} 1} \mathrm{~V}_{1}+\mathrm{P}_{\mathrm{V} 2} \mathrm{~V}_{2}+\mathrm{P}_{\mathrm{F} 1} \mathrm{~F}_{1}+\mathrm{P}_{\mathrm{F} 2} \mathrm{~F}_{2}+\mathrm{P}_{\mathrm{R} 1} \mathrm{R}_{1}+\mathrm{P}_{\mathrm{R} 2} \mathrm{R}_{2}$

Where:

$\mathrm{V}_{1}=$ Quantity by sq meter of tomatoes

$\mathrm{V}_{2}=$ Quantity by sq meter of green pepper

$F_{1}=$ Quantity by sq meter of gerbera

$\mathrm{F}_{2}=$ Quantity by sq meter of poinsettia

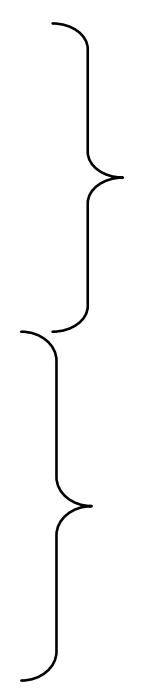

Vegetables

$\mathrm{R}_{1}=$ Quantity by sq meter of strawberries

$\mathrm{R}_{2}=$ Quantity by sq meter of watermelon

$\mathrm{P}_{\mathrm{V} 1}=$ Profit by sq meter produced of tomatoes

$\mathrm{P}_{\mathrm{V} 2}=$ Profit by sq meter produced of green peppers

$\mathrm{P}_{\mathrm{F} 1}=$ Profit by sq meter produced of gerbera

$\mathrm{P}_{\mathrm{F} 2}=$ Profit by sq meter produced of poinsettia 
$\mathrm{P}_{\mathrm{R} 1}=$ Profit by sq meter produced of strawberry

$\mathrm{P}_{\mathrm{R} 2}=$ Profit by sq meter produced of watermelon

Subject to :

Land availability:

$$
\begin{aligned}
& V_{1}+V_{2}+F_{1}+F_{2}+R_{1}+R_{2} \geq 1500 \\
& V_{1}+V_{2}+F_{1}+F_{2}+R_{1}+R_{2} \leq 2000
\end{aligned}
$$

Water availability:

$$
227.5 \mathrm{~V}_{1}+195 \mathrm{~V}_{2}+540 \mathrm{~F}_{1}+540 \mathrm{~F}_{2}+455 \mathrm{R}_{1}+195 \mathrm{R}_{2} \leq 20000000
$$

Labor availability:

$$
0.25 V_{1}+0.16 V_{2}+0.06 F_{1}+0.08 F_{2}+0.1 R_{1}+0.16 R_{2} \leq 4880
$$

Capital availability:

$$
236.5 V_{1}+60 V_{2}+180 F_{1}+180 F_{2}+42 R_{1}+21 R_{2} \leq 150,000
$$

Income generations:

$$
193.5 V_{1}+120 V_{2}+180 F_{1}+180 F_{2}+63 R_{1}+21 R_{2} \leq 180,000
$$

Minimum space planted by type of crop:

$$
\begin{gathered}
V_{1}+V_{2} \geq 100 \\
F_{1}+F_{2} \geq 100 \\
R_{1}+R_{2} \geq 100 \\
V_{1}, V_{2}, F_{1}, F_{2}, R_{1}, R_{2} \geq 0
\end{gathered}
$$


The RHS land availability constraint is limited by the minimum space of the total greenhouse area to have profits.

The RHS water availability constraint is limited by the maximum amount of water that a small producer can pump a year.

The RHS labor availability constraint is limited by the number of workers used in a 2000sqm greenhouse.

The RHS capital availability constraint is limited by the average working capital for a 2000sqm greenhouse.

The RHS income generations constraint is limited by the average incomes for a 4-members family in rural area forecast.

The RHS for the minimum space planted by type of crop is limited by for the minimum space that can be planted in the greenhouse, it is a line in a bed inside the greenhouse.

The software packages Excel and Visual Basic (for enterprises budgets, NPV and IRR calculations, for the decision-support tool); and TORA (for the LP model) were used. 


\section{CHAPTER IV}

\subsection{RESULTS}

\subsubsection{Production and Market Assessment:}

To fulfill the objectives for this study the NVP and the IRR were calculated using standard economic and financial techniques by mean of Excel.

The NVP, IRR, BEP(break-even point), and net incomes above variable costs were calculated, for three different scenarios: pessimistic, moderate and optimistic. The results are based on annual calculations(described in Figure 5). Data from the National System of Market Information (Sistema Nacional de Información de Mercados, SNIIM) were used to calibrate the scenarios: for the most likely scenario, the average prices of this system were used; for the pessimistic scenery the prices were one standard deviation less than this mean, and for the optimistic scenario, prices were one standard deviation above the mean. The results for tomatoes are shown in the table below; results for the other crops are included in appendix B.

\section{PROJECT ANALYSIS}

\section{TOMATO}

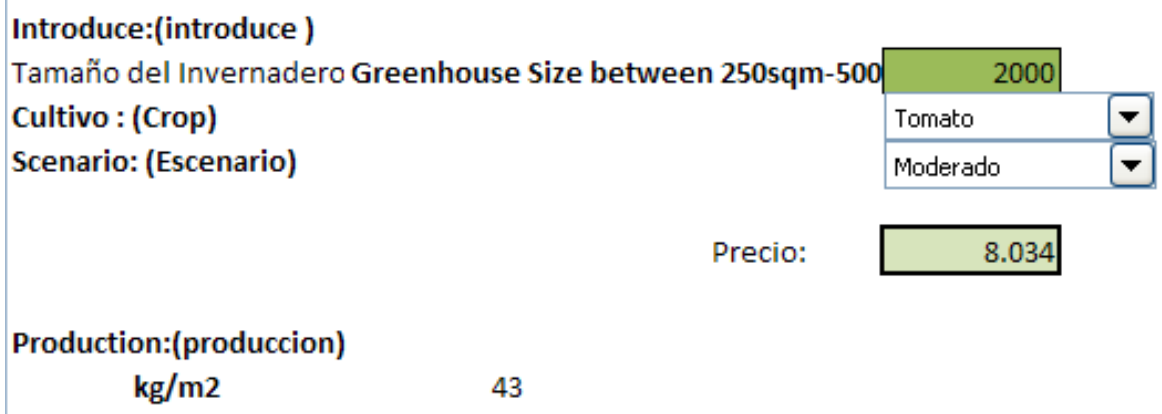




\begin{tabular}{l|c}
\hline \multicolumn{2}{|l}{ Resumen: } \\
\hline \multicolumn{2}{|c}{} \\
\hline Costo de Producion/kg & 3.50 \\
\hline SALES QUANTITY & 86000.00 \\
\hline TOTAL REVENUES & 422349.44 \\
\hline PROFIT B/F TX & 422349.44 \\
\hline & \\
PROFIT A/TX & 332343.60 \\
\hline BEP & 170520.34 \\
\hline IRR & \\
\hline NPV & $29 \%$ \\
\hline
\end{tabular}

Figure 5. NPV,IRR \& BEP summary

In the study, six different crops, likely candidates for greenhouse production, were considered assuming a 2000sq meters greenhouse (previous, unpublished research indicates that this is the minimum size operation needed to support a family of 4-5 persons). As indicated previously, the analysis was conducted with three scenarios based on the market price and using the standard deviation of those historical prices found in the SNIIM (Sistema Nacional de Información e Integración de Mercados). A summary of these results is shown in table 5 below.

Table 5.Summary for three scenarios.

\begin{tabular}{|c|c|c|c|c|c|c|c|c|c|c|c|c|}
\hline Scenario & & Pesi & imistic & & & Mode & erate & & & Optin & istic & \\
\hline Crop & BEP(kg) & \begin{tabular}{|l|} 
NPV \\
(MXP) \\
\end{tabular} & IRR & Profit & BEP(kg) & \begin{tabular}{|l|l} 
NPV \\
(MXP)
\end{tabular} & IRR & Profit & $\operatorname{BEP}(\mathbf{k g})$ & \begin{tabular}{|l|}
$\mathbf{N P V}$ \\
(MXP)
\end{tabular} & IRR & Profit \\
\hline Tomato & 23348 & 140 & $5 \%$ & 135241 & 13775 & 416 & $29 \%$ & 332344 & 9770 & 972 & $49 \%$ & 529446 \\
\hline $\begin{array}{l}\text { Green } \\
\text { pepper }\end{array}$ & 7562 & 430 & $27 \%$ & 77425 & 5635 & 690 & $38 \%$ & 115754 & 4491 & 950 & $48 \%$ & 154084 \\
\hline Gerbera & 22404 & 194 & $16 \%$ & 4720 & 19050 & 325 & $22 \%$ & 67191 & 16569 & 455 & $27 \%$ & 87175 \\
\hline Poinsettia & 19071 & 298 & $18 \%$ & 74508 & 15964 & 467 & $24 \%$ & 100464 & 13840 & 627 & $30 \%$ & 124908 \\
\hline Strawberry & 6277 & 120 & $13 \%$ & 39279 & 5392 & 204 & $17 \%$ & 52210 & 4726 & 288 & $20 \%$ & 65140 \\
\hline
\end{tabular}


\begin{tabular}{|l||l} 
Watermelon & 19335 \\
\hline
\end{tabular} \begin{tabular}{l|l}
$47 \quad 10 \%$ \\
\hline
\end{tabular} \begin{tabular}{l||l|l|l|}
60903 & 16122 & 88.79 & $12 \%$
\end{tabular} $74423 \quad 13824$ 87943 


\subsubsection{Governmental policies and Financial opportunities}

Next, is listing of some of the government-provided producer support programs and institutions who provide credit to small producers.

1. PIDEFIMER. (Program of Induction and Development of Rural Areas): Financing that is established in the 15 articles of the agreement in which the Rules of Operation of the SAGARPA programs are specified. Their target population is the financial intermediaries who render services to rural areas; individual or corporate entities who in an organized way, make activities of hiring and dispersion of credits in the rural area; and individual or corporate entities who in an individual or group way, conduct agricultural, livestock, fishing, aquaculture, or agribusiness in rural areas, without access or difficulties to receive financing through conventional means, and regardless of whether the applicant is a man or a woman.

2. FINCAS. It is an Inversion and Capitalization Fund, understand as: A liquid warranty trust or an Alternative Pay Source, so, its converted in an instrument for risk administration, integrated by the producers who organize and assume the responsibility of constitute a partial financial warranty system.

3. FIRA. Established in 1954 by Mexico's federal government, Trust Funds for Rural Development (FIRA) is a second-tier development bank that offers credit and guarantees, training, technical assistance and technology-transfer support to the agriculture, livestock, fishing, forestry and agribusiness sectors in Mexico.

\section{Products \& Services.}

FIRA offers a diverse range of products and services to support the development of the rural sector. It provides short-term and long-term credit in pesos and US dollars through financial intermediaries at competitive interest rates. Credit guarantees are provided to banks as a way 
to share the risk with lending institutions and to facilitate access to bank credit by rural producers. FIRA also uses financial derivatives and structured financing to manage the risk involved in everyday operations. (www.fira.gob.mx)

Among the broad range of products and services offered by FIRA, we find:

\section{FIRA Credit}

- Medium term credit (2 years max) for working capital.

- Fixed investments up to 15 years. For forestry and long maturity projects it can be extended up to 20 years.

- Short term credit for the commercialization of goods and services, for up to 6 months.

\section{Rural Financing}

This product's objective is to foment any other economic activity, different from the agricultural, forestry or fishing activities, in rural Mexico. For instance: transportation, distribution, warehouses, bakeries, general stores, etc. (www.fira.gob.mx)

\section{FIRA Guarantee}

Offered to the traditional banking Institutions and other financial intermediaries, in order to facilitate the access to producers and/or businessmen to the FIRA's financing programs by complementing their guarantees for feasible projects in the agricultural and rural sectors. (www.fira.gob.mx)

\section{Structured Financing}

The objective is to provide specific, tailor-made funding programs to companies with specific needs. These schemes are developed from identifying the credit, operative and market risks, so they can be managed accordingly. (www.fira.gob.mx) 


\section{Special programs}

These are specially developed schemes to address particular topics, from financial support to sugar producers to Credit Unions schemes. (www.fira.gob.mx)

\section{Technologic subsidies}

Management training and technology transfer

Integral Technical Assistance Services

Strengthen Economic Organizations and Enterprises

Strengthen Financial and Management Competencies of Financial Intermediaries

Expansion of the Business Promotion Structures with FIRA.(www.fira.gob.mx)

For all the government programs above mentioned is a requirement to have a rural association or to be a small grower ("Ejidatario"), if only one person want to be beneficiate for the program.

\subsubsection{LP MODEL}

The objective function of the linear programming model was specified to maximize profits above variable costs in a 2000sqm greenhouse with a mixed production of at least one type of vegetable, fruit and flower in an area of at least 100sqm per crop. It was also specified to cover a minimum of 1500 sqm of the greenhouse (the remaining 500 sq meters could be used for storage, etc.).

In addition to evaluating the results for three price scenarios, a sensitivity analysis, to examine the impacts of changes in capital availability on the optimal solution was also conduced. 
In the LP model for this project the minimum area selected of 100sqm was considered due to the fact that the irrigation system for each line in each bed inside the greenhouse, is approximately 100sqm.

In Table 6 below, the results of the optimization analysis for this model using the constrains of the original model, for three different scenarios, are summarized. It is observed that green peppers generates the highest profit in the three scenarios. In the pessimistic scenario the model shows that 100 sqm of gerbera and 100 sqm of strawberries have to be planted to obtain the maximum profit, generating MXP \$196,000 \$770 and \$7,500 respectively with a total profit of $\$ 204,270$ in the total area. In the most likely scenario the model shows that 1800 sqm of green pepper, 100sqm of gerbera and 100sqm of Strawberries have to be planted to obtain the maximum profit, generating $\$ 295,000 \mathrm{MXP}, \$ 3,600$ and $\$ 9,400$ respectively, with a total profit of $\$ 308,000$ in the total area. In the optimistic scenario the results show that 112 sqm of Tomato, 1688sqm of green pepper, 100sqm of Poinsettia and 100sqm of Strawberries have to be planted to obtain the maximum profit, generating MXP $\$ 27,000, \$ 370,000, \$ 6,500$ and $\$ 11,000$ respectively, with a total profit of $\$ 414,500$ in the total area.

Table 6. LP Model results with, available capital of MXP \$ 150,000

\begin{tabular}{|c|c|c|c|c|c|c|}
\hline \multirow[b]{2}{*}{ Crops } & \multicolumn{2}{|c|}{ Pesimistic } & \multicolumn{2}{|c|}{ Moderate } & \multicolumn{2}{|c|}{ Optimistic } \\
\hline & $\begin{array}{c}\text { Sq meters by } \\
\text { plant }\end{array}$ & $\begin{array}{c}\text { Optimal Solution } \\
\text { Value }\end{array}$ & $\begin{array}{c}\text { Sq meters by } \\
\text { plant }\end{array}$ & $\begin{array}{c}\text { Optimal Solution } \\
\text { Value }\end{array}$ & $\begin{array}{c}\text { Sq meters by } \\
\text { plant }\end{array}$ & $\begin{array}{c}\text { Optimal Solution } \\
\text { Value }\end{array}$ \\
\hline Tomato & & & & & 112 & $\$ 27,000$ \\
\hline Green Papper & 1800 & $\$ 196,000$ & 1,800 & $\$ 295,000$ & 1,688 & $\$ 370,000$ \\
\hline Gerbera & 100 & $\$ 770$ & 100 & $\$ 3,600$ & & \\
\hline Poinsettia & & & & & 100 & $\$ 6,500$ \\
\hline Strawberry & 100 & $\$ 7,500$ & 100 & $\$ 9,400$ & 100 & $\$ 11,000$ \\
\hline Watermelon & & & & & & \\
\hline Total: & 2000 & $\$ 204,270$ & 2,000 & $\$ 308,000$ & 2,000 & $\$ 414,500$ \\
\hline
\end{tabular}

The results of the sensitivity analysis, where in the available capital is reduced by $\$ 50,000$, are shown in Table 7. 
In the worst case or pessimistic scenario, the model shows that 1289 sqm of Green Pepper, 111 sqm of Strawberry and 100sqm of Gerbera have to be planted to obtain the maximum profit, generating MXP $\$ 140,000, \$ 770$ and $\$ 8,400$ respectively with a total profit of $\$ 149,170$ in the total area. In the most likely scenario the model shows that 1300 sqm of green pepper, 100sqm of gerbera and 100sqm of strawberries have to be planted to obtain the maximum profit, generating MXP $\$ 212,000, \$ 3,600$ and $\$ 8500$ respectively, with a total profit of $\$ 224,100$ in the total area. In the best case( or optimistic) scenario the results shows that 1300 sqm, 100 sqm of poinsettia and 100 sqm of strawberry have to be planted to obtain the maximum profit, generating MXP $\$ 284,000, \$ 6,500$ and $\$ 10,000$ respectively, with a total profit of $\$ 300,500$ in the total area.

Table 7. Sensitivity Analysis for the LP Model with, available capital of \$100,000 MP

\begin{tabular}{|l|c|c|c|c|c|c|}
\hline & \multicolumn{2}{|c|}{ Pesimistic } & \multicolumn{2}{c|}{ Moderate } & \multicolumn{2}{c|}{ Optimistic } \\
\hline \multicolumn{1}{|c|}{ Crops } & $\begin{array}{c}\text { Sq meters by } \\
\text { plant }\end{array}$ & $\begin{array}{c}\text { Optimal Solution } \\
\text { Value }\end{array}$ & $\begin{array}{c}\text { Sq meters by } \\
\text { plant }\end{array}$ & $\begin{array}{c}\text { Optimal Solution } \\
\text { Value }\end{array}$ & $\begin{array}{c}\text { Sq meters by } \\
\text { plant }\end{array}$ & $\begin{array}{c}\text { Optimal Solution } \\
\text { Value }\end{array}$ \\
\hline Tomato & & & & & & \\
\hline Green Papper & 1289 & $\$ 140,000$ & 1,300 & $\$ 212,000$ & 1,300 & $\$ 284,000$ \\
\hline Gerbera & 100 & $\$ 770$ & 100 & $\$ 3,600$ & & \\
\hline Noche buena & & & & & 100 & $\$ 6,500$ \\
\hline Strawberry & 111 & $\$ 8,400$ & 100 & $\$ 8,500$ & 100 & $\$ 10,000$ \\
\hline Watermelon & & & & & & \\
\hline \hline Total: & $\mathbf{1 5 0 0}$ & $\mathbf{\$ 1 4 9 , 1 7 0}$ & $\mathbf{1 , 5 0 0}$ & $\mathbf{2 2 4 , 1 0 0}$ & $\mathbf{1 , 5 0 0}$ & $\mathbf{\$ 3 0 0 , 5 0 0}$ \\
\hline \hline
\end{tabular}

Next, the results of the sensitivity where the available capital is increased by $\$ 150,000$ are discussed.

In the pessimistic scenario the model shows that 1800.00 sqm of Green Pepper, 100.00sqm of Gerbera and 100sqm Strawberry of have to be planted to obtain the maximum profit, generating MXP $\$ 196,000, \$ 780$ and $\$ 7,500$ respectively with a total profit of $\$ 204,280$ in the complete 2000sqm. In the moderate or most likely scenario the model shows that 1800 sqm of green pepper, 100sqm of gerbera and 100sqm of strawberries have to be planted 
to obtain the maximum profit, generating MXP $\$ 295,000, \$ 3,600$ and $\$ 9,400$ respectively, with a total profit of $\$ 308,000$ in the total area. In the optimistic scenario the results shows that 962 sqm of tomatoes, 838 sqm of green peppers, 100sqm of strawberries and 100sqm of poinsettias have to be planted to obtain the maximum profit, generating MXP $\$ 230,000$, $\$ 180,000, \$ 6500$ and $\$ 11,000$ respectively, with a total profit of $\$ 427,500$ in the total area.

Table 8.Sensitivity Analysis for the LP Model increasing the available capital to $\$ 300,000$ MP

\begin{tabular}{|l|c|c|c|c|c|c|}
\hline & \multicolumn{2}{|c|}{ Pesimistic } & \multicolumn{2}{c|}{ Moderate } & \multicolumn{2}{c|}{ Optimistic } \\
\hline \multicolumn{1}{|c|}{ Crops } & $\begin{array}{c}\text { Sq meters by } \\
\text { plant }\end{array}$ & $\begin{array}{c}\text { Optimal Solution } \\
\text { Value }\end{array}$ & $\begin{array}{c}\text { Sq meters by } \\
\text { plant }\end{array}$ & $\begin{array}{c}\text { Optimal Solution } \\
\text { Value }\end{array}$ & $\begin{array}{c}\text { Sq meters by } \\
\text { plant }\end{array}$ & $\begin{array}{c}\text { Optimal Solution } \\
\text { Value }\end{array}$ \\
\hline Tomato & & & & & 962 & $\$ 230,000$ \\
\hline Green Papper & 1800 & $\$ 196,000$ & 1,800 & $\$ 295,000$ & 838 & $\$ 180,000$ \\
\hline Gerbera & 100 & $\$ 780$ & 100 & $\$ 3,600$ & & \\
\hline Noche buena & & & & & 100 & $\$ 6,500$ \\
\hline Strawberry & 100 & $\$ 7,500$ & 100 & $\$ 9,400$ & 100 & $\$ 11,000$ \\
\hline Watermelon & & & & & & \\
\hline \hline Total: & $\mathbf{2 0 0 0}$ & $\mathbf{\$ 2 0 4 , 2 8 0}$ & $\mathbf{2 , 0 0 0}$ & $\mathbf{\$ 3 0 8 , 0 0 0}$ & $\mathbf{2 , 0 0 0}$ & $\$ \mathbf{\$ 4 2 7 , 5 0 0}$ \\
\hline \hline
\end{tabular}

NPV \& IRR for the LP Model results

Using the results from the LP Model the next table shows the NPV and the IRR, for the three scenarios, assuming a 10-year planning horizon.

Table 9. NPV \& IRR for the LP Model results

\begin{tabular}{|c|c|c|c|c|c|}
\hline \multicolumn{2}{|c|}{ Pesimistic } & \multicolumn{2}{c|}{ Moderate } & \multicolumn{2}{c|}{ Optimistic } \\
\hline NPV(x1000MXP) $^{\mid}$ & IRR & NPV(x1000MXP) & IRR & NPV(x1000MXP) $_{1}$ & IRR \\
\hline 718 & $24 \%$ & 1,358 & $43 \%$ & 2,015 & $61 \%$ \\
\hline \hline
\end{tabular}

\subsubsection{Production Cost, total revenues and profits.}

In the next table, the total sales quantity, the production cost, total revenues and the profits after taxes for the optimistic scenario, for a 2000sqm greenhouse, are shown. (The complete calculations are shown in the appendix B). 
The production per sqm of tomatoes is $43 \mathrm{~kg}$ with a production cost of $3.50 \mathrm{MXP} / \mathrm{kg}$. The price considered per sqm for this scenario was $\$ 11.04 \mathrm{MXP}$ obtaining $\$ 696,102.92$ before taxes and \$529,446.10MXP after taxes.

The production per sqm of green pepper is $12 \mathrm{~kg}$ with a production cost of $2.50 \mathrm{MXP} / \mathrm{kg}$. The price considered per sqm for this scenario was $\$ 23.18 \mathrm{MXP}$ obtaining $\$ 435,896.00$ before taxes and \$304,282.40MXP after taxes.

The production per sqm of gerbera is 36 plants with a production cost of $2.50 \mathrm{MXP} / \mathrm{kg}$. The price considered per sqm for this scenario was $\$ 6.80$ MXP obtaining $\$ 308,928.00$ before taxes and \$221,753.20MXP after taxes.

The production per sqm of poinsettia is 36 plans with a production cost of $3.00 \mathrm{MXP} / \mathrm{kg}$. The price considered per sqm for this scenario was $\$ 8.00 \mathrm{MXP}$ obtaining $\$ 356,880.00$ before taxes and $\$ 231,972.00 \mathrm{MXP}$ after taxes.

The production per sqm of strawberry is $7 \mathrm{~kg}$ with a production cost of $6.00 \mathrm{MXP} / \mathrm{kg}$. The price considered per sqm for this scenario was $\$ 22.06 \mathrm{MXP}$ obtaining $\$ 230,974.00$ before taxes and \$165,833.10MXP after taxes.

The production per sqm of watermelon is $10 \mathrm{kgs}$ with a production cost of $2.10 \mathrm{MXP} / \mathrm{kg}$. The price considered per sqm for this scenario was $\$ 8.01 \mathrm{MXP}$ obtaining $\$ 127,220.00$ before taxes and $\$ 87,943.00 \mathrm{MXP}$ after taxes.

Table 10. Optimistic scenario, summary of sales quantity, production costs, total revenues and profits.

\begin{tabular}{|l||c|c|c|c||}
\hline \multicolumn{1}{|l||}{ Scenario } & \multicolumn{4}{|c||}{ Optimistic } \\
\hline \multicolumn{1}{c||}{ Crop } & $\begin{array}{l}\text { Sales qty } \\
(\text { Kg) }\end{array}$ & $\begin{array}{l}\text { Prod Cost } \\
\text { (MXP/Kg) }\end{array}$ & $\begin{array}{l}\text { Total Revenues } \\
\text { (MXP) }\end{array}$ & $\begin{array}{l}\text { Profit After taxes } \\
\text { (MXP) }\end{array}$ \\
\hline Tomato & 86000 & 3.50 & 696102 & 529446 \\
\hline Green Papper & 24000 & 2.50 & 435896 & 304282 \\
\hline Gerbera & 72000 & 2.50 & 308928 & 221753 \\
\hline Poinsettia & 72000 & 3.00 & 356880 & 231972 \\
\hline Strawberry & 14000 & 6.00 & 230974 & 165833 \\
\hline
\end{tabular}


\begin{tabular}{|l||c|c|c|c||} 
Watermelon & 20000 & 2.10 & 127220 & 87943 \\
\hline
\end{tabular}

In table 11 below, the total sales quantity, the production cost, total revenues and the profits after taxes for the moderate scenario, for a 2000sqm greenhouse, are shown.

For this scenario just the price was changed as is explained in the methodology taking the standard deviation method. The production per sqm of tomatoes is the same in each scenario and also the production cost. The price considered per sqm for this scenario was $\$ 8.03 \mathrm{MXP}$ obtaining \$422,350 revenues before taxes and \$332,344MXP after taxes.

The production per sqm of green pepper is the same in each scenario and also the production cost. The price considered per sqm for this scenario was $\$ 18.62 \mathrm{MXP}$ obtaining $\$ 326,384$ revenues before taxes and $\$ 233,100 \mathrm{MXP}$ after taxes.

The production per sqm of gerbera is the same in each scenario and also the production cost. The price considered per sqm for this scenario was $\$ 6.01 \mathrm{MXP}$ obtaining $\$ 251,832$ revenues before taxes and $\$ 184,640 \mathrm{MXP}$ after taxes.

The production per sqm of poinsettia is the same in each scenario and also the production cost. The price considered per sqm for this scenario was $\$ 7.03 \mathrm{MXP}$ obtaining $\$ 287,040$ revenues before taxes and $\$ 186,576 \mathrm{MXP}$ after taxes.

For this scenario just the price was changed as is explained in the methodology taking the standard deviation method. The production per sqm of strawberry is the same in each scenario and also the production cost. The price considered per sqm for this scenario was \$19.42MXP obtaining \$194,028 revenues before taxes and \$141,818MXP after taxes.

The production per sqm of watermelon is the same in each scenario and also the production cost. The price considered per sqm for this scenario was $\$ 6.97 \mathrm{MXP}$ obtaining $\$ 106,420$ revenues before taxes and $\$ 74,423 \mathrm{MXP}$ after taxes. 
Table 11. Most likely scenario, summary of sales quantity, production costs, total revenues and profits.

\begin{tabular}{|c|c|c|c|c|}
\hline \multirow{2}{*}{$\begin{array}{r}\text { Scenario } \\
\text { Crop } \\
\end{array}$} & \multicolumn{4}{|c|}{ Moderate } \\
\hline & \begin{tabular}{|l|}
$\begin{array}{l}\text { Sales qty } \\
(\mathrm{Kg})\end{array}$ \\
\end{tabular} & \begin{tabular}{|l|} 
Prod Cost \\
$(\mathrm{MXP} / \mathrm{Kg})$
\end{tabular} & \begin{tabular}{|l}
$\begin{array}{l}\text { Total Revenues } \\
\text { (MXP) }\end{array}$ \\
\end{tabular} & $\begin{array}{l}\text { Profit After taxes } \\
\text { (MXP) } \\
\end{array}$ \\
\hline Tomato & 86000.00 & 3.50 & 422350 & 332344 \\
\hline Green Papper & 24000.00 & 5.00 & 326384 & 233100 \\
\hline Gerbera & 72000.00 & 2.50 & 251832 & 184640 \\
\hline Poinsettia & 72000.00 & 3.00 & 287040 & 186576 \\
\hline Strawberry & 14000.00 & 6.00 & 194028 & 141818 \\
\hline Watermelon & 20000.00 & 2.10 & 106420.00 & 74423 \\
\hline
\end{tabular}

In table 12, the total sales quantity, the production cost, total revenues and the profits after taxes for the pessimistic scenario, for a 2000sqm greenhouse, are shown.

For this scenario only the price was changed as is explained in the methodology taking the standard deviation method. The production per sqm of tomato is the same in each scenario and also the production cost. The price considered per sqm for this scenario was $\$ 5.03 \mathrm{MXP}$ obtaining \$148,595 revenues before taxes and \$135,241MXP after taxes.

The production per sqm of green pepper is the same in each scenario and also the production cost. The price considered per sqm for this scenario was $\$ 14.05 \mathrm{MXP}$ obtaining $\$ 216,872$ revenues before taxes and $\$ 161,916 \mathrm{MXP}$ after taxes.

The production per sqm of gerbera is the same in each scenario and also the production cost. The price considered per sqm for this scenario was \$5.21MXP obtaining \$194,736 revenues before taxes and $\$ 147,528 \mathrm{MXP}$ after taxes.

The production per sqm of poinsettia is the same in each scenario and also the production cost. The price considered per sqm for this scenario was $\$ 6.00 \mathrm{MXP}$ obtaining $\$ 212,880$ revenues before taxes and \$138,372MXP after taxes.

The production per sqm of strawberry is the same in each scenario and also the production cost. The price considered per sqm for this scenario was $\$ 16.78 \mathrm{MXP}$ obtaining $\$ 157,082$ revenues before taxes and $\$ 117,803 \mathrm{MXP}$ after taxes. 
The production per sqm of watermelon is the same in each scenario and also the production cost. The price considered per sqm for this scenario was $\$ 5.93 \mathrm{MXP}$ obtaining $\$ 85,620$ revenues before taxes and $\$ 60,903 \mathrm{MXP}$ after taxes.

Table 12. Pessimistic scenario, summary of sales quantity, production costs, total revenues and profits.

\begin{tabular}{|l||c|c|c|c||}
\hline \multicolumn{1}{|l||}{ Scenario } & \multicolumn{4}{|c||}{ Pessimistic } \\
\hline \multicolumn{1}{c||}{ Crop } & $\begin{array}{l}\text { Sales qty } \\
(\text { Kg) }\end{array}$ & $\begin{array}{l}\text { Prod Cost } \\
(\mathbf{M X P / K g})\end{array}$ & $\begin{array}{l}\text { Total Revenues } \\
\text { (MXP) }\end{array}$ & $\begin{array}{l}\text { Profit After taxes } \\
\text { (MXP) }\end{array}$ \\
\hline \multicolumn{1}{|l||}{ Tomato } & 86000.00 & 3.50 & 148595 & 135241 \\
\hline Green Papper & 24000.00 & 5.00 & 216872 & 161916 \\
\cline { 2 - 5 } Gerbera & 72000.00 & 2.50 & 194736 & 147528 \\
\hline Poinsettia & 72000.00 & 3.00 & 212880 & 138372 \\
\hline Strawberry & 14000.00 & 6.00 & 157082 & 117803 \\
\hline Watermelon & 20000.00 & 2.10 & 85620 & 60903 \\
\hline
\end{tabular}

\subsubsection{Decision-support tool for small producers to facilitate producer-level} decision making.

A decision-support tool was developing in Excel to provide small producers a tool to take the best decision to obtain a loan from a commercial bank or any credit institution. They can introduce the period of the credit, the interest rates and their incomes to know if they can obtain this credit. The tool has different bank interest rate and is easy to update it. The spread sheet was created in English and Spanish version. (The complete tool is shown in the appendix C). 


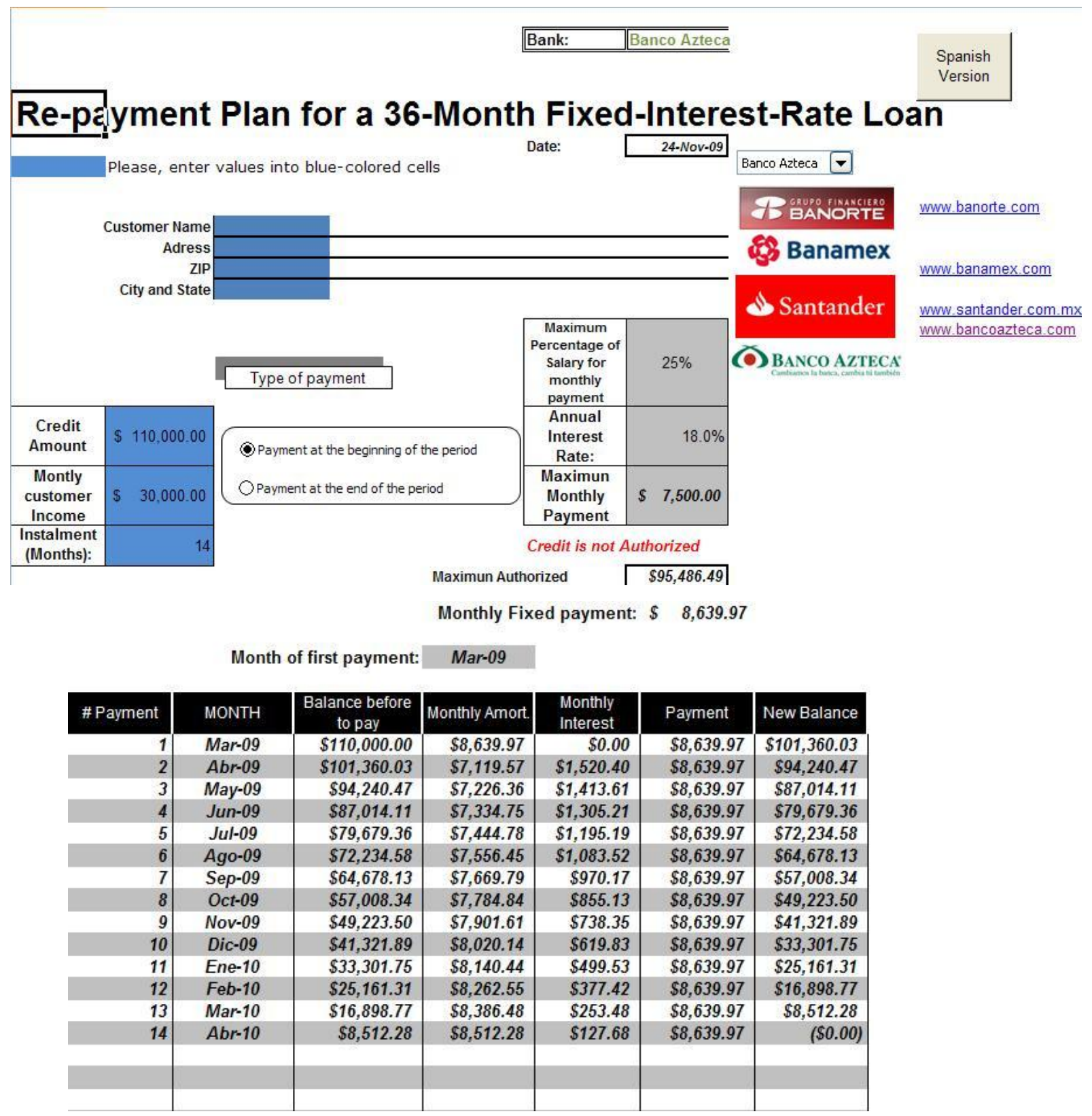

Figure 6. Re-payment plan for a 14-month Fixed-Interest-Rate Loan 


\subsubsection{Simulation of cash flows using the $L P$ model results}

Using the cost for a greenhouse of 2000sqm and the LP model optimal solution results in the next figure is show an illustration of a repayment plan for a 36-month Fixed-Interest-Rate loan. For the Pessimistic scenario we observed that the credit is not authorized.

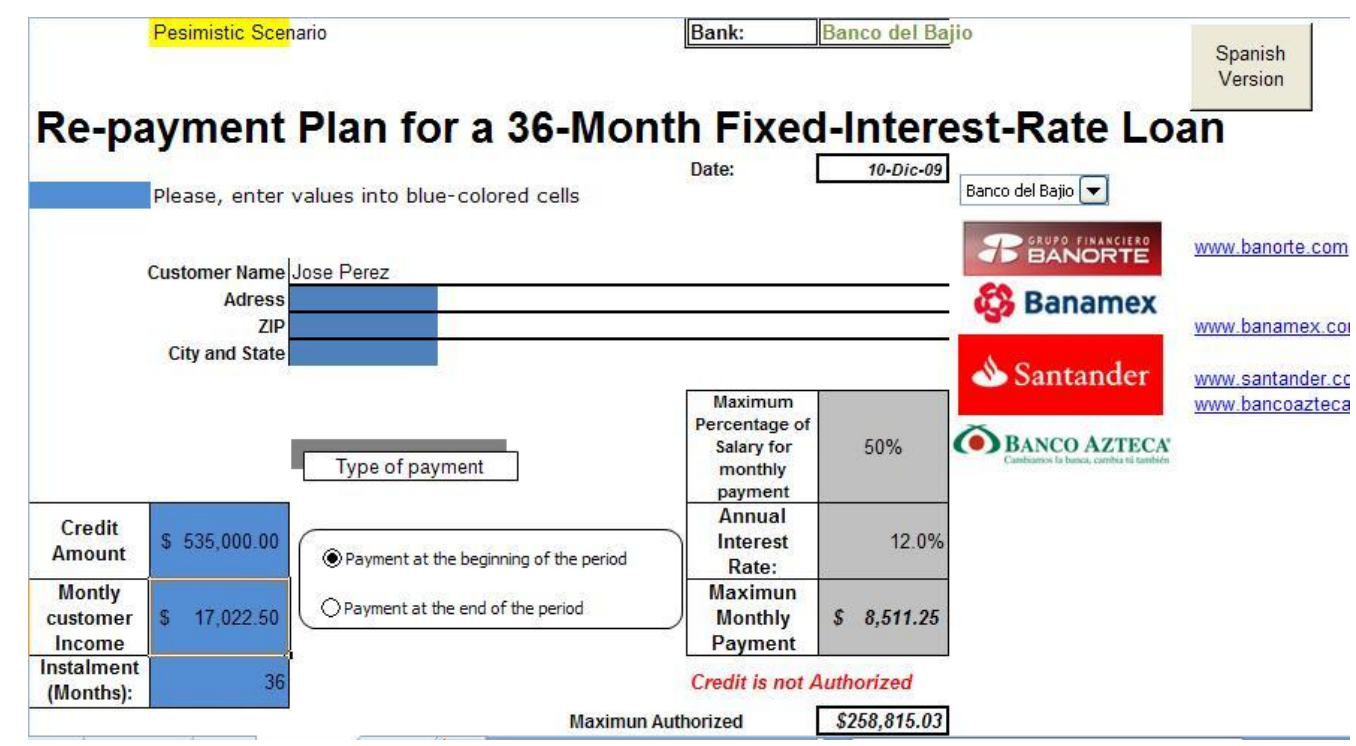


Month of first payment: Mar-09

\begin{tabular}{|c|c|c|c|c|c|c|}
\hline \# Payment & MONTH & $\begin{array}{c}\text { Balance before } \\
\text { to pay }\end{array}$ & Monthly Amort. & $\begin{array}{l}\text { Monthly } \\
\text { Interest }\end{array}$ & Payment & New Balance \\
\hline 1 & Mar-09 & $\$ 535,000.00$ & $\$ 17.593 .72$ & $\$ 0.00$ & $\$ 17.593 .72$ & $\$ 517,406.28$ \\
\hline 2 & $A b r-09$ & $\$ 517,406.28$ & $\$ 12,419.66$ & $\$ 5,174.06$ & $\$ 17,593.72$ & $\$ 504,986.63$ \\
\hline 3 & May-09 & $\$ 504,986.63$ & $\$ 12,543.85$ & $\$ 5,049.87$ & $\$ 17,593.72$ & $\$ 492,442.77$ \\
\hline 4 & Jun-09 & $\$ 492,442.77$ & $\$ 12,669.29$ & $\$ 4,924.43$ & $\$ 17,593.72$ & $\$ 479,773.48$ \\
\hline 5 & Jul-09 & $\$ 479,773.48$ & $\$ 12,795.98$ & $\$ 4,797.73$ & $\$ 17,593.72$ & $\$ 466,977.50$ \\
\hline 6 & Ago-09 & $\$ 466,977.50$ & $\$ 12,923.94$ & $\$ 4,669.77$ & $\$ 17,593.72$ & $\$ 454,053.56$ \\
\hline 7 & Sep-09 & $\$ 454,053.56$ & $\$ 13,053.18$ & $\$ 4,540.54$ & $\$ 17,593.72$ & $\$ 441,000.37$ \\
\hline 8 & Oct-09 & $\$ 441,000.37$ & $\$ 13,183.71$ & $\$ 4,410.00$ & $\$ 17,593.72$ & $\$ 427,816.66$ \\
\hline 9 & Nov-09 & $\$ 427,816.66$ & $\$ 13,315.55$ & $\$ 4,278.17$ & $\$ 17,593.72$ & $\$ 414,501.11$ \\
\hline 10 & Dic-09 & $\$ 414,501.11$ & $\$ 13,448.71$ & $\$ 4,145.01$ & $\$ 17,593.72$ & $\$ 401,052.40$ \\
\hline 11 & Ene-10 & $\$ 401,052.40$ & $\$ 13,583.19$ & $\$ 4,010.52$ & $\$ 17,593.72$ & $\$ 387,469.20$ \\
\hline 12 & Feb-10 & $\$ 387,469.20$ & $\$ 13,719.03$ & $\$ 3,874.69$ & $\$ 17,593.72$ & $\$ 373,750.18$ \\
\hline 13 & Mar-10 & $\$ 373,750.18$ & $\$ 13,856.22$ & $\$ 3,737.50$ & $\$ 17,593.72$ & $\$ 359,893.96$ \\
\hline 14 & $A b r-10$ & $\$ 359,893.96$ & $\$ 13,994.78$ & $\$ 3,598.94$ & $\$ 17,593.72$ & $\$ 345,899.18$ \\
\hline 15 & May-10 & $\$ 345,899.18$ & $\$ 14,134.73$ & $\$ 3,458.99$ & $\$ 17,593.72$ & $\$ 331,764.45$ \\
\hline 16 & Jun-10 & $\$ 331,764.45$ & $\$ 14,276.07$ & $\$ 3,317.64$ & $\$ 17,593.72$ & $\$ 317,488.38$ \\
\hline 17 & Jul-10 & $\$ 317,488.38$ & $\$ 14,418.83$ & $\$ 3,174.88$ & $\$ 17,593.72$ & $\$ 303,069.55$ \\
\hline 18 & Ago-10 & $\$ 303,069.55$ & $\$ 14,563.02$ & $\$ 3,030.70$ & $\$ 17,593.72$ & $\$ 288,506.52$ \\
\hline 19 & Sep-10 & $\$ 288,506.52$ & $\$ 14,708.65$ & $\$ 2,885.07$ & $\$ 17,593.72$ & $\$ 273,797.87$ \\
\hline 20 & Oct-10 & $\$ 273,797.87$ & $\$ 14,855.74$ & $\$ 2,737.98$ & $\$ 17,593.72$ & $\$ 258,942.13$ \\
\hline 21 & Nov-10 & $\$ 258,942.13$ & $\$ 15,004.30$ & $\$ 2,589.42$ & $\$ 17,593.72$ & $\$ 243,937.83$ \\
\hline 22 & Dic-10 & $\$ 243,937.83$ & $\$ 15,154.34$ & $\$ 2,439.38$ & $\$ 17,593.72$ & $\$ 228,783.49$ \\
\hline 23 & Ene-11 & $\$ 228,783.49$ & $\$ 15,305.88$ & $\$ 2,287.83$ & $\$ 17,593.72$ & $\$ 213,477.61$ \\
\hline 24 & Feb-11 & $\$ 213,477.61$ & $\$ 15,458.94$ & $\$ 2,134.78$ & $\$ 17,593.72$ & $\$ 198,018.67$ \\
\hline 25 & Mar-11 & $\$ 198,018.67$ & $\$ 15,613.53$ & $\$ 1,980.19$ & $\$ 17,593.72$ & $\$ 182,405.13$ \\
\hline 26 & $A b r-11$ & $\$ 182,405.13$ & $\$ 15,769.67$ & $\$ 1,824.05$ & $\$ 17,593.72$ & $\$ 166,635.47$ \\
\hline 27 & May-11 & $\$ 166,635.47$ & $\$ 15,927.36$ & $\$ 1,666.35$ & $\$ 17,593.72$ & $\$ 150,708.10$ \\
\hline 28 & Jun-11 & $\$ 150,708.10$ & $\$ 16,086.64$ & $\$ 1,507.08$ & $\$ 17,593.72$ & $\$ 134,621.46$ \\
\hline 29 & Jul-11 & $\$ 134,621.46$ & $\$ 16,247.50$ & $\$ 1,346.21$ & $\$ 17,593.72$ & $\$ 118,373.96$ \\
\hline 30 & Ago-11 & $\$ 118,373.96$ & $\$ 16,409.98$ & $\$ 1,183.74$ & $\$ 17,593.72$ & $\$ 101,963.98$ \\
\hline 31 & Sep-11 & $\$ 101,963.98$ & $\$ 16,574.08$ & $\$ 1,019.64$ & $\$ 17,593.72$ & $\$ 85,389.90$ \\
\hline 32 & Oct-11 & $\$ 85,389.90$ & $\$ 16,739.82$ & $\$ 853.90$ & $\$ 17,593.72$ & $\$ 68,650.08$ \\
\hline 33 & Nov-11 & $\$ 68,650.08$ & $\$ 16,907.22$ & $\$ 686.50$ & $\$ 17,593.72$ & $\$ 51,742.87$ \\
\hline 34 & Dic-11 & $\$ 51,742.87$ & $\$ 17,076.29$ & $\$ 517.43$ & $\$ 17,593.72$ & $\$ 34,666.58$ \\
\hline 35 & Ene-12 & $\$ 34,666.58$ & $\$ 17,247.05$ & $\$ 346.67$ & $\$ 17,593.72$ & $\$ 17,419.52$ \\
\hline 36 & Feb-12 & $\$ 17,419.52$ & $\$ 17,419.52$ & $\$ 174.20$ & $\$ 17,593.72$ & $\$ 0.00$ \\
\hline & & & $\$ 535,000.00$ & $\$ 98,373.87$ & $\$ 633,373.87$ & \\
\hline
\end{tabular}

Figure 7. Part 1 Pessimistic Scenario 
For the most likely scenario we observed in the next figure that the credit is not authorized.

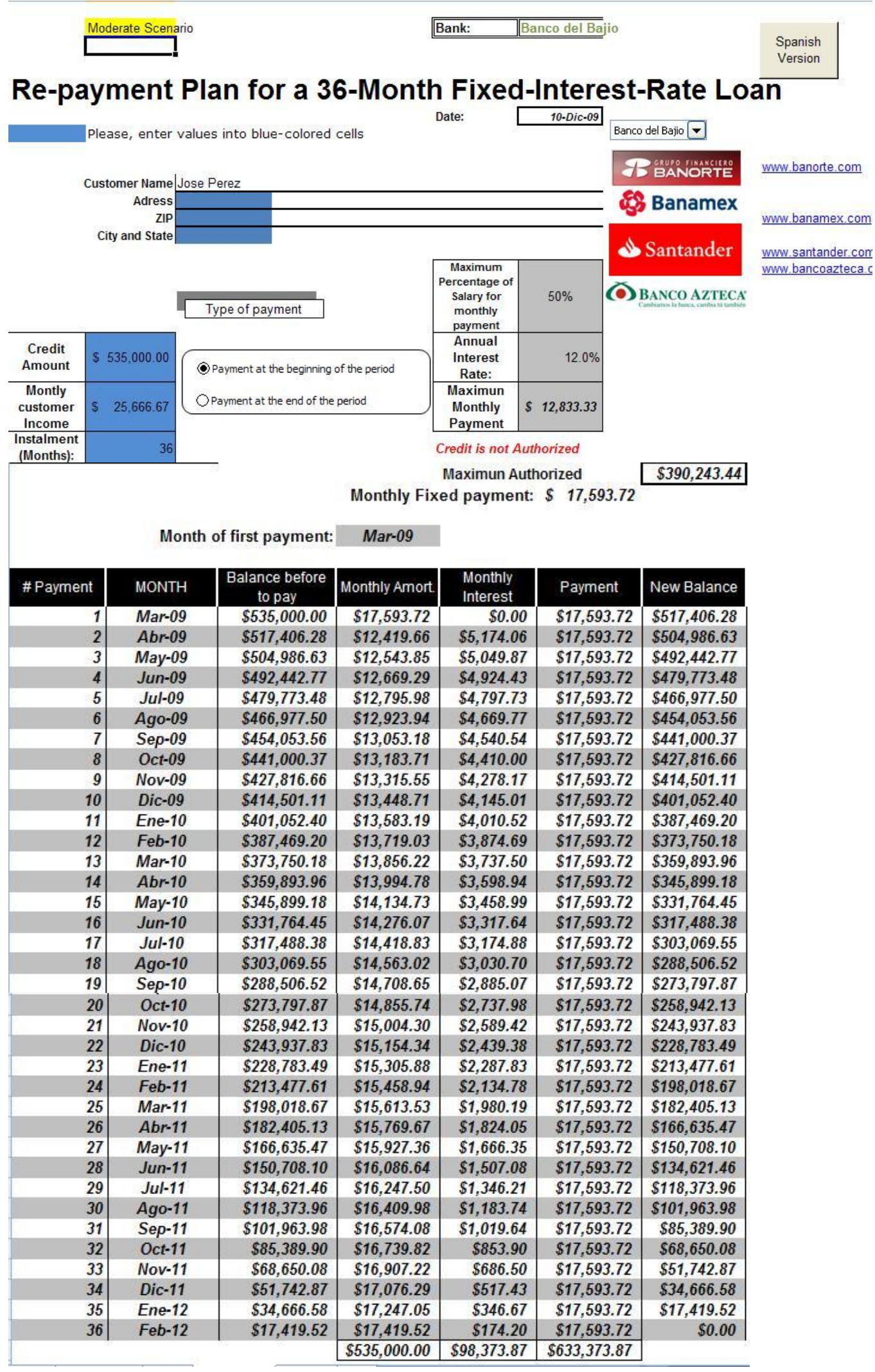

Figure 8. Part 2 Moderate Scenario

For the optimistic scenario (Figure 9 below), credit is authorized. 


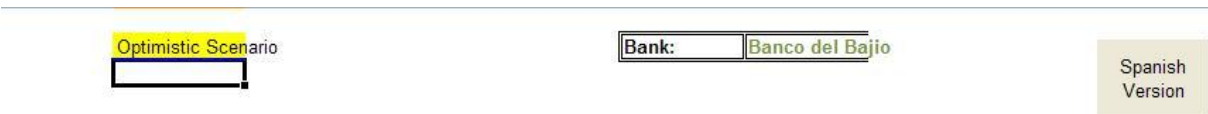

Re-payment Plan for a 36-Month Fixed-Interest-Rate Loan

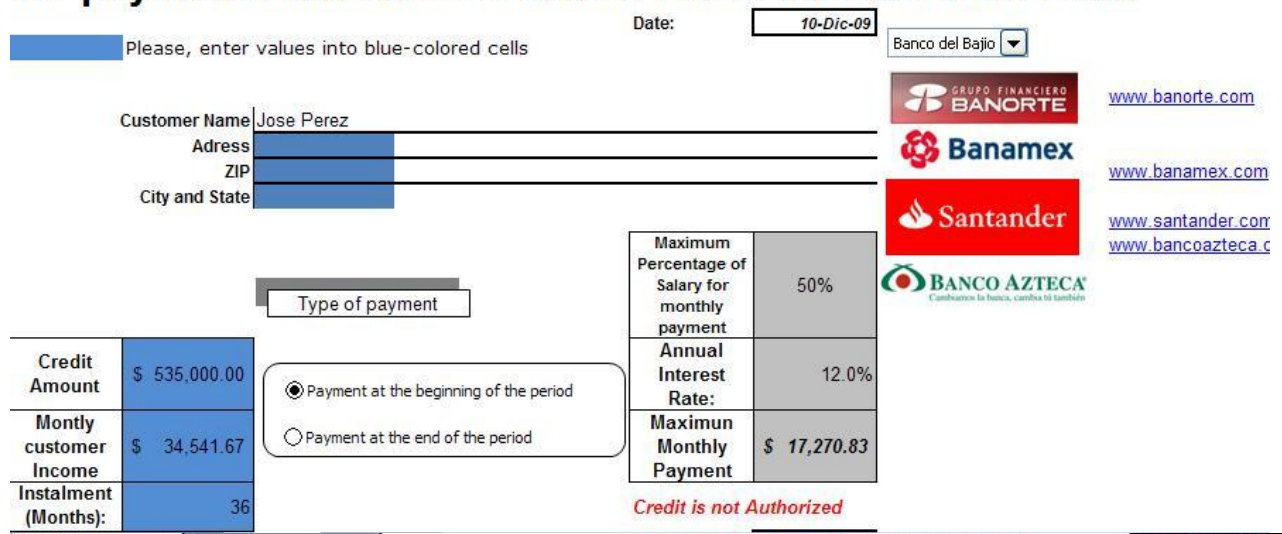

Maximun Authorized

Monthly Fixed payment: $\$ 17,593.72$

$\$ 525,181.52$

Month of first payment: Mar-09

\begin{tabular}{|c|c|c|c|c|c|c|}
\hline \# Payment & MONTH & $\begin{array}{c}\text { Balance before } \\
\text { to pay }\end{array}$ & Monthly Amort. & $\begin{array}{l}\text { Monthly } \\
\text { Interest }\end{array}$ & Payment & New Balance \\
\hline 1 & Mar-09 & $\$ 535,000.00$ & $\$ 17,593.72$ & $\$ 0.00$ & $\$ 17,593.72$ & $\$ 517,406.28$ \\
\hline 2 & $A b r-09$ & $\$ 517,406.28$ & $\$ 12,419.66$ & $\$ 5,174.06$ & $\$ 17,593.72$ & $\$ 504,986.63$ \\
\hline 3 & May-09 & $\$ 504,986.63$ & $\$ 12,543.85$ & $\$ 5,049.87$ & $\$ 17,593.72$ & $\$ 492,442.77$ \\
\hline 4 & Jun-09 & $\$ 492,442.77$ & $\$ 12,669.29$ & $\$ 4,924.43$ & $\$ 17,593.72$ & $\$ 479,773.48$ \\
\hline 5 & Jul-09 & $\$ 479,773.48$ & $\$ 12,795.98$ & $\$ 4,797.73$ & $\$ 17,593.72$ & $\$ 466,977.50$ \\
\hline 6 & Ago-09 & $\$ 466,977.50$ & $\$ 12,923.94$ & $\$ 4,669.77$ & $\$ 17,593.72$ & $\$ 454,053.56$ \\
\hline 7 & Sep-09 & $\$ 454,053.56$ & $\$ 13,053.18$ & $\$ 4,540.54$ & $\$ 17,593.72$ & $\$ 441,000.37$ \\
\hline 8 & Oct-09 & $\$ 441,000.37$ & $\$ 13,183.71$ & $\$ 4,410.00$ & $\$ 17,593.72$ & $\$ 427,816.66$ \\
\hline 9 & Nov-09 & $\$ 427,816.66$ & $\$ 13,315.55$ & $\$ 4,278.17$ & $\$ 17,593.72$ & $\$ 414,501.11$ \\
\hline 10 & Dic-09 & $\$ 414,501.11$ & $\$ 13,448.71$ & $\$ 4,145.01$ & $\$ 17,593.72$ & $\$ 401,052.40$ \\
\hline 11 & Ene-10 & $\$ 401,052.40$ & $\$ 13,583.19$ & $\$ 4,010.52$ & $\$ 17,593.72$ & $\$ 387,469.20$ \\
\hline 12 & Feb-10 & $\$ 387,469.20$ & $\$ 13,719.03$ & $\$ 3,874.69$ & $\$ 17,593.72$ & $\$ 373,750.18$ \\
\hline 13 & Mar-10 & $\$ 373,750.18$ & $\$ 13,856.22$ & $\$ 3,737.50$ & $\$ 17,593.72$ & $\$ 359,893.96$ \\
\hline 14 & $A b r-10$ & $\$ 359,893.96$ & $\$ 13,994.78$ & $\$ 3,598.94$ & $\$ 17,593.72$ & $\$ 345,899.18$ \\
\hline 15 & May-10 & $\$ 345,899.18$ & $\$ 14,134.73$ & $\$ 3,458.99$ & $\$ 17,593.72$ & $\$ 331,764.45$ \\
\hline 16 & Jun-10 & $\$ 331,764.45$ & $\$ 14,276.07$ & $\$ 3,317.64$ & $\$ 17,593.72$ & $\$ 317,488.38$ \\
\hline 17 & Jul-10 & $\$ 317,488.38$ & $\$ 14,418.83$ & $\$ 3,174.88$ & $\$ 17,593.72$ & $\$ 303,069.55$ \\
\hline 18 & Ago-10 & $\$ 303,069.55$ & $\$ 14,563.02$ & $\$ 3,030.70$ & $\$ 17,593.72$ & $\$ 288,506.52$ \\
\hline 19 & Sep-10 & $\$ 288,506.52$ & $\$ 14,708.65$ & $\$ 2,885.07$ & $\$ 17,593.72$ & $\$ 273,797.87$ \\
\hline 20 & Oct-10 & $\$ 273,797.87$ & $\$ 14,855.74$ & $\$ 2,737.98$ & $\$ 17,593.72$ & $\$ 258,942.13$ \\
\hline 21 & Nov-10 & $\$ 258,942.13$ & $\$ 15,004.30$ & $\$ 2,589.42$ & $\$ 17,593.72$ & $\$ 243,937.83$ \\
\hline 22 & Dic-10 & $\$ 243,937.83$ & $\$ 15,154.34$ & $\$ 2,439.38$ & $\$ 17,593.72$ & $\$ 228,783.49$ \\
\hline 23 & Ene-11 & $\$ 228,783.49$ & $\$ 15,305.88$ & $\$ 2,287.83$ & $\$ 17,593.72$ & $\$ 213,477.61$ \\
\hline 24 & Feb-11 & $\$ 213,477.61$ & $\$ 15,458.94$ & 34.78 & $\$ 17,593.72$ & $\$ 198,018.67$ \\
\hline 25 & Mar-11 & $\$ 198,018.67$ & $\$ 15,613.53$ & $\$ 1,980.19$ & $\$ 17,593.72$ & $\$ 182,405.13$ \\
\hline 26 & $A b r-11$ & $\$ 182,405.13$ & $\$ 15,769.67$ & $\$ 1,824.05$ & $\$ 17,593.72$ & $\$ 166,635.47$ \\
\hline 27 & May-11 & $\$ 166,635.47$ & $\$ 15,927.36$ & $\$ 1,666.35$ & $\$ 17,593.72$ & $\$ 150,708.10$ \\
\hline 28 & Jun-11 & $\$ 150,708.10$ & $\$ 16,086.64$ & $\$ 1,507.08$ & $\$ 17,593.72$ & $\$ 134,621.46$ \\
\hline 29 & Jul-11 & $\$ 134,621.46$ & $\$ 16,247.50$ & $\$ 1,346.21$ & $\$ 17,593.72$ & $\$ 118,373.96$ \\
\hline 30 & Ago-11 & $\$ 118,373.96$ & $\$ 16,409.98$ & $\$ 1,183.74$ & $\$ 17,593.72$ & $\$ 101,963.98$ \\
\hline 31 & Sep-11 & $\$ 101,963.98$ & $\$ 16,574.08$ & $\$ 1,019.64$ & $\$ 17,593.72$ & $\$ 85,389.90$ \\
\hline 32 & Oct-11 & $\$ 85,389.90$ & $\$ 16,739.82$ & $\$ 853.90$ & $\$ 17,593.72$ & $\$ 68,650.08$ \\
\hline 33 & Nov-11 & $\$ 68,650.08$ & $\$ 16,907.22$ & $\$ 686.50$ & $\$ 17,593.72$ & $\$ 51,742.87$ \\
\hline 34 & Dic-11 & $\$ 51,742.87$ & $\$ 17,076.29$ & $\$ 517.43$ & $\$ 17,593.72$ & $\$ 34,666.58$ \\
\hline 35 & Ene-12 & $\$ 34,666.58$ & $\$ 17,247.05$ & $\$ 346.67$ & $\$ 17,593.72$ & $\$ 17,419.52$ \\
\hline 36 & Feb-12 & $\$ 17,419.52$ & $\$ 17,419.52$ & $\$ 174.20$ & $\$ 17,593.72$ & $\$ 0.00$ \\
\hline & & & $\$ 535,000.00$ & $\$ 98,373.87$ & $\$ 633,373.87$ & \\
\hline
\end{tabular}

Figure 9. Part 3 Optimistic Scenario 
4.1.2.5 Simulation of cash flows using the LP model results and 50\% subsidies for greenhouse price.

Using the cost for a greenhouse 2000sqm and the LP model optimal solution results in figure 10 is show a repayment plan for 36-month Fixed-Interest-Rate loan and a government subsidy of 50\%. For the Pessimistic scenario we observed that the credit is not authorized.

Using the cost for a greenhouse 2000sqm and the LP model optimal solution results in the figure 11 is show a repayment plan for 36-month Fixed-Interest-Rate loan and a government subsidy of $50 \%$. For the moderate scenario we observed that the credit is authorized.

Using the cost for a greenhouse 2000sqm and the LP model optimal solution results in the figure 12 is show a repayment plan for 36-month Fixed-Interest-Rate loan and a government subsidy of $50 \%$. For the optimistic scenario we observed that the credit is authorized. 


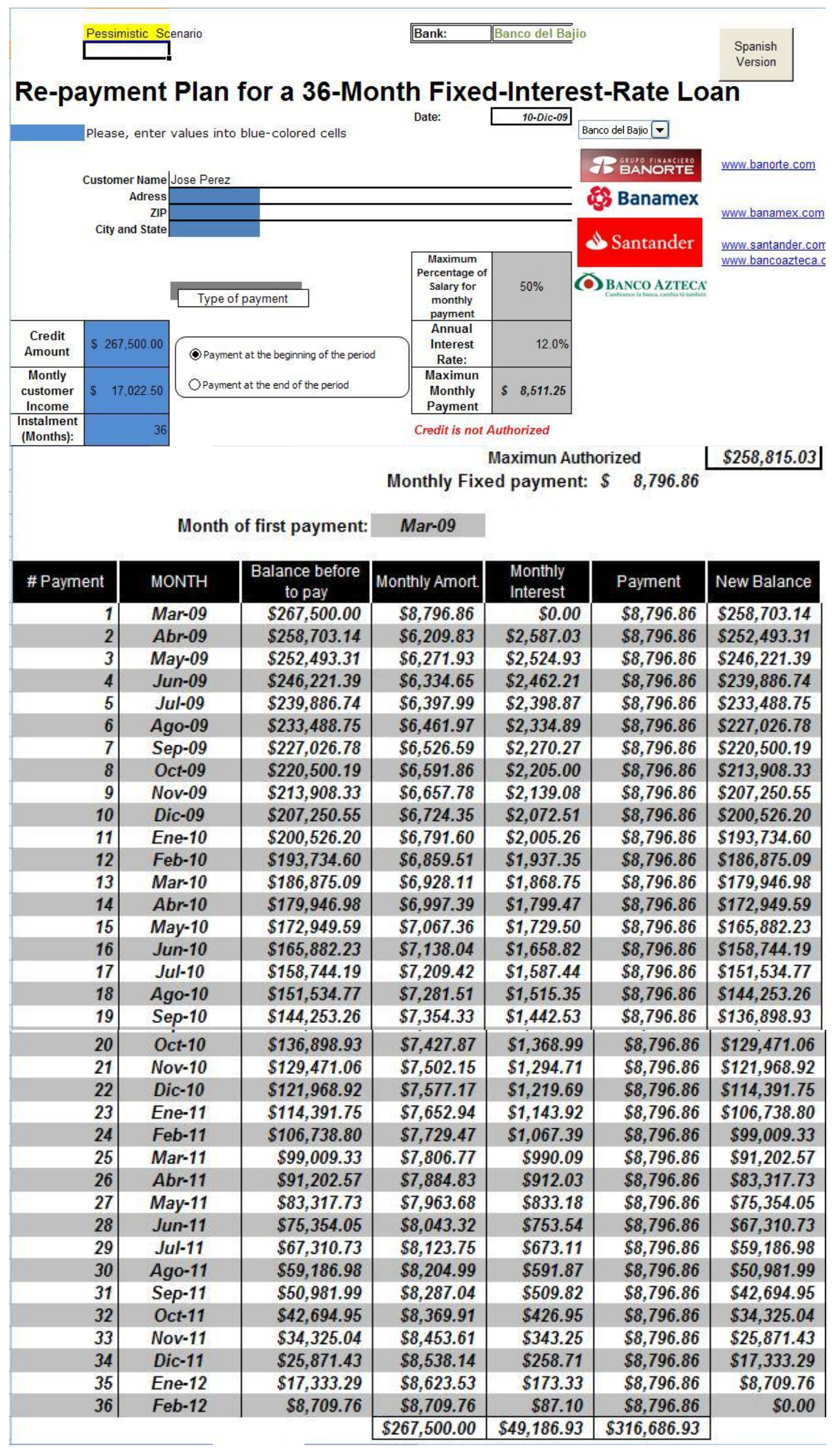

Figure 10. Simulation with subsidy part 1 


\section{\begin{tabular}{lll}
\hline Most likely Scenario & Bank: $[$ Banco del Bajio & Spanish \\
Version \\
\hline
\end{tabular} \\ Re-payment Plan for a 36-Month Fixed-Interest-Rate Loan}

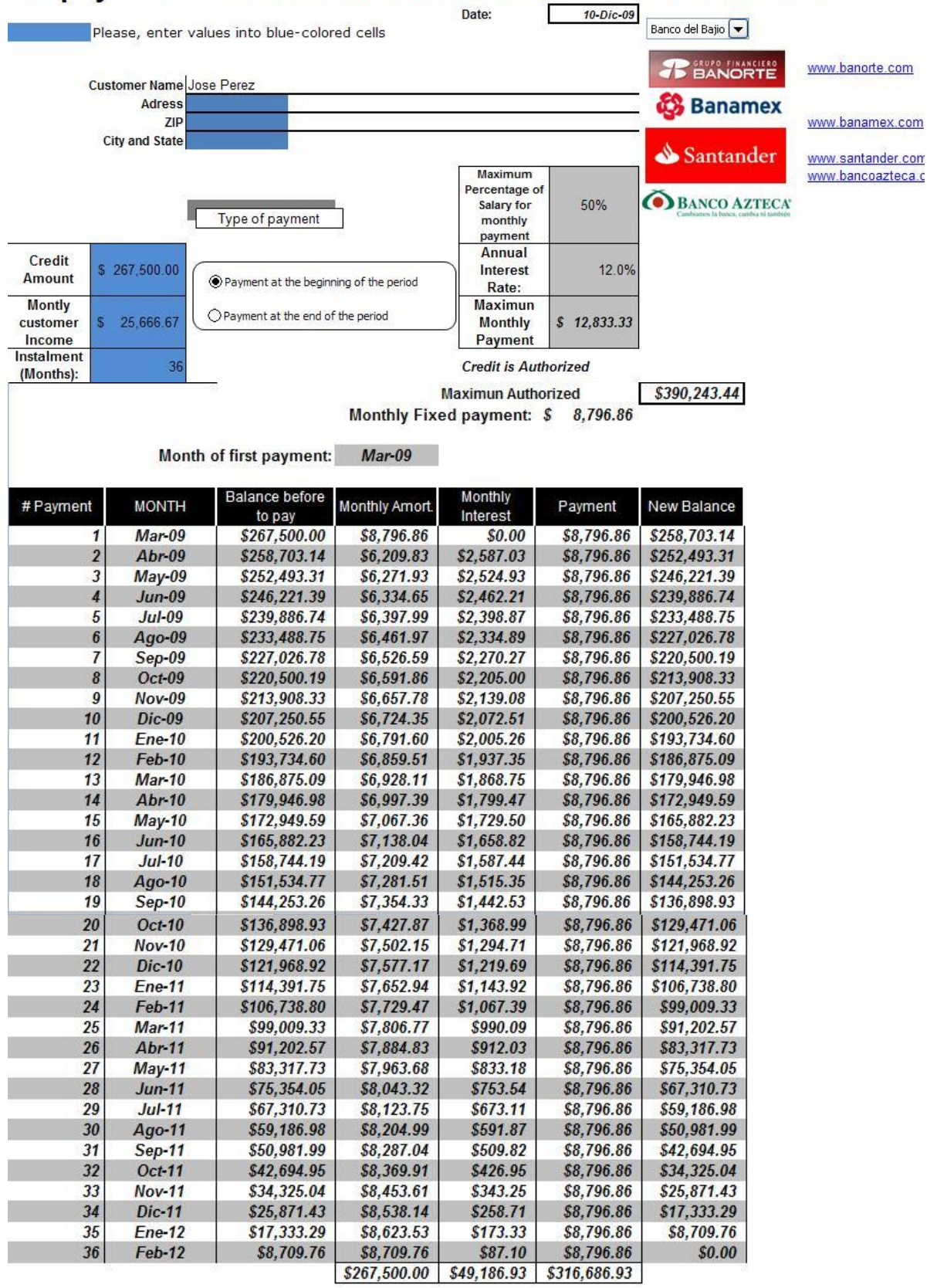

Figure 11. Simulation with subsidy part2 


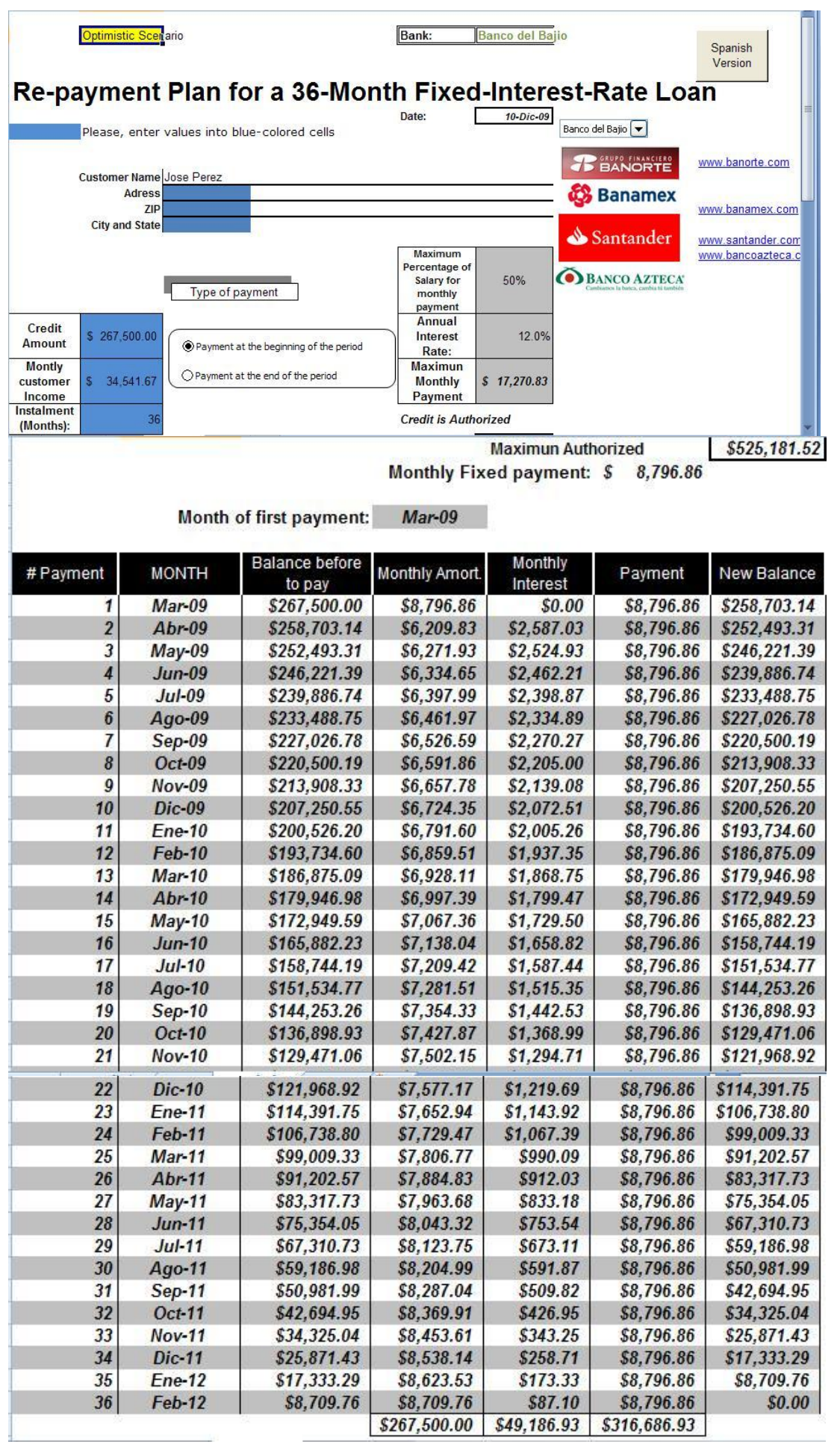

Figure 12. Simulation with subsidy part 3 
With the objective of know part of the requirements of commercialization (the author of this project, 2002) a meeting with a broker was organized in the UAQ, who visited the greenhouse department of the Engineering Faculty who give some recommendations, for example, to export the product it is necessary to send by land a container of 18 tons per week, a commission of $12 \%$ is paid, the product must be transported to a city in the border and the broker store the product and then they commercialize it.

To export agriculture products the following methodology is used. First the target market must be identified, after it is necessary to check the duty regulations or other type of regulations, and then the logistic (package, transport, etc.). (BANCOMEXT, Mexican Exterior Commerce Bank)

In figures 7,8 and 9 are shown some grading standard sizes for tomatoes in California in the United States which is one of the requisites to be considered to import this product to California.

\section{CALIFORNIA TOMATO SIZES}

\section{U.S. Grading Standard Minimum - Maximum \\ Size Designations Diameter}

\begin{tabular}{cc}
\hline Small - 7x7 & 2 4/32" - 2 9/32" \\
Medium - 6x7 & 2 8/32" - 2 17/32" \\
Large - 6x6 & 2 16/32" - 2 25/32" \\
Extra Large - 5x6 and larger & 2 24/32" and larger \\
\hline California tomatoes are marketed under U.S. Grading Standards
\end{tabular}

Figure 13. U.S. grading standards for California tomatoes 


\begin{tabular}{ccc}
$\begin{array}{c}\text { Numerical } \\
\text { Size Designations }\end{array}$ & $\begin{array}{c}\text { Tomatoes per } \\
\text { Container }\end{array}$ & $\begin{array}{c}\text { Layers per } \\
\text { Container }\end{array}$ \\
\hline $3 \times 4$ & 24 & 2 \\
$4 \times 4$ & 32 & 2 \\
$4 \times 5$ & 40 & 2 \\
$5 \times 5$ & 50 & 2 \\
$5 \times 6$ & 60 & 2 \\
$6 \times 6$ & 108 & 3 \\
$6 \times 7$ & 126 & 3 \\
$7 \times 7$ & 147 & 3 \\
\hline
\end{tabular}

Figure 14. Hand-pack tomato count per box

As is shown in the next pictures the tomato must fit exactly in to the space of the container so that the product is proved for importing.
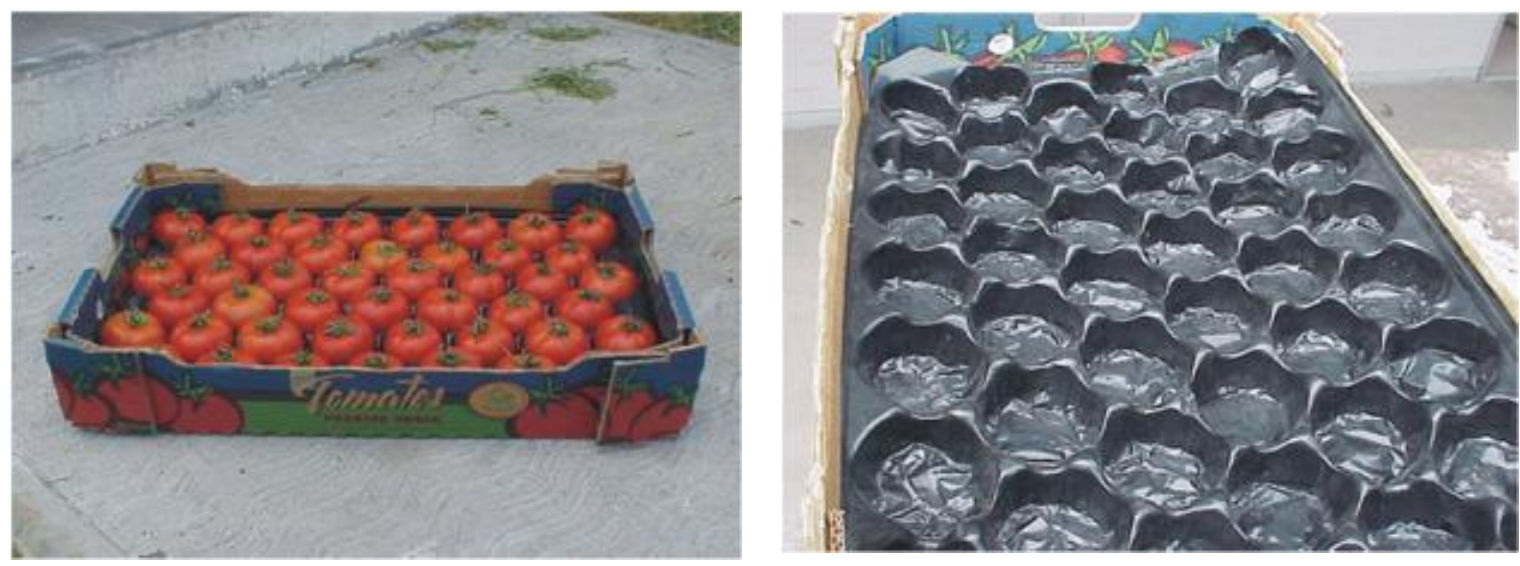

Figure 15.Tomatoes picture from UAQ.

The exporting requirements for Mexican agricultural products have some differences between the products. The products must be accepted products by the importing country. Mexico has a free trade agreement with USA and Canada, but not all products are accepted by these 
countries. In the next figure is the PPQ Form 587 form that the producer has to fill to start the exporting to the USA process. The complete form is shown in appendix $\mathrm{E}$

Source: Foreign Agricultural Service, USDA, http://www.fas.usda.gov, y para el consumo per cápita la base de datos del Economic Research Service, USDA.

\section{Markets: Consolidate WithPotencial Niche}

Mexican Exportations to USA, 2002-2007

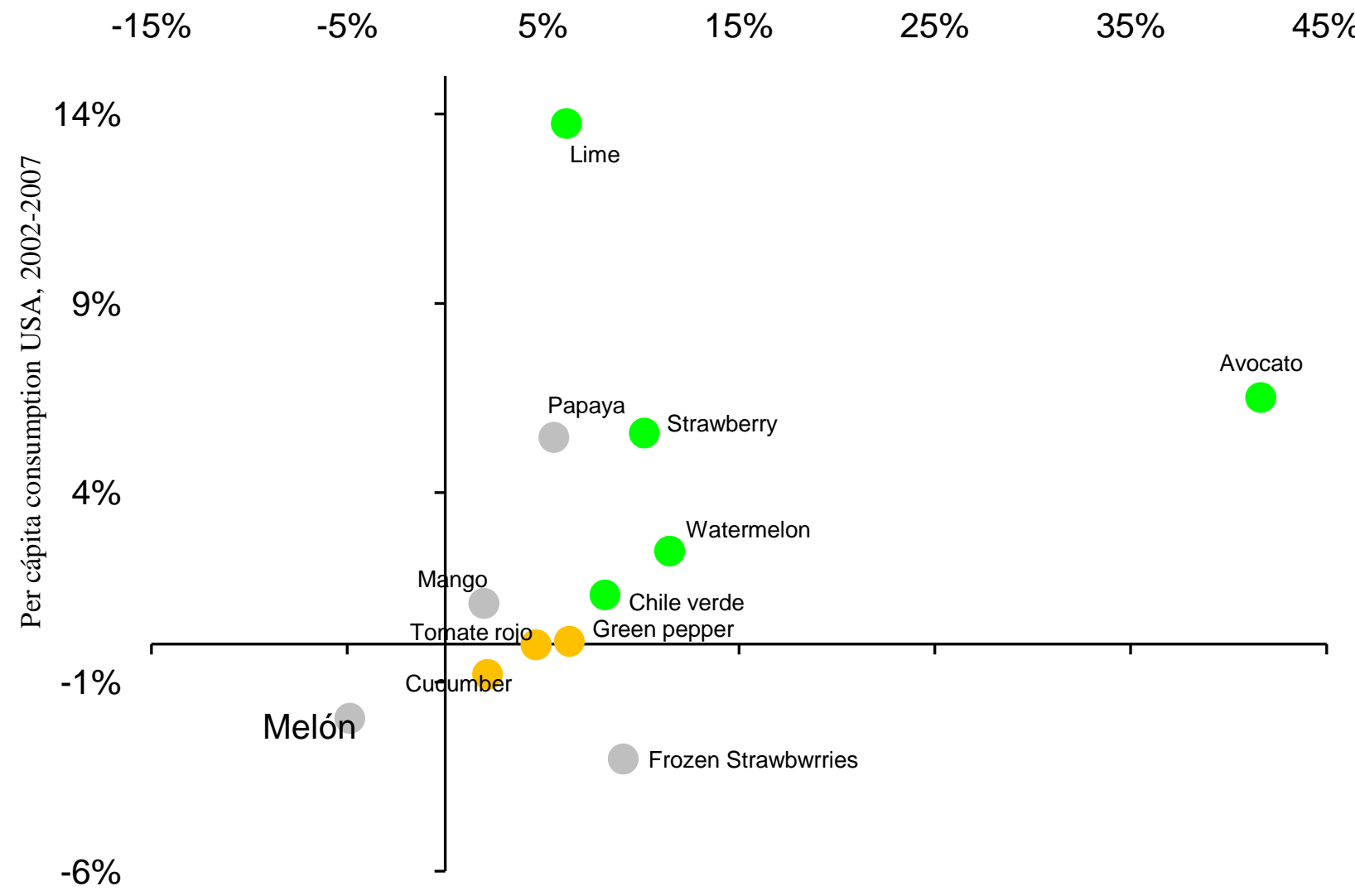

Figure 16. Opportunity market for some exported products. 
Table 13. Mexican participation in US market for some agricultural products.

\begin{tabular}{|c|c|c|c|}
\hline \multirow{2}{*}{ Crop } & $\begin{array}{c}\text { Total } \\
\text { Importation } \\
\text { to EE UU } \\
\end{array}$ & $\begin{array}{l}\text { Exportation } \\
\text { from } \\
\text { México to } \\
\text { EE UU } \\
\end{array}$ & \multirow{2}{*}{$\begin{array}{l}\text { Mexican } \\
\text { Participation } \\
\text { in US } \\
\text { Market }\end{array}$} \\
\hline & \multicolumn{2}{|c|}{$\begin{array}{c}2007 \\
\text { (Million of dollars ) }\end{array}$} & \\
\hline Avocado & 554 & 444 & $80 \%$ \\
\hline Jalapeño & 261 & 255 & $98 \%$ \\
\hline Lime & 216 & 179 & $83 \%$ \\
\hline Water melon & 158 & 140 & $89 \%$ \\
\hline Strawberry & 132 & 131 & $99 \%$ \\
\hline Tomato & 1,220 & 960 & $79 \%$ \\
\hline Grape & 960 & 262 & $27 \%$ \\
\hline Green pepper & 535 & 313 & $59 \%$ \\
\hline Cucumber & 471 & 379 & $80 \%$ \\
\hline Squash & 214 & 205 & $96 \%$ \\
\hline Orange Juice & 626 & 127 & $20 \%$ \\
\hline Canalope & 254 & 66 & $26 \%$ \\
\hline Mango & 196 & 117 & $60 \%$ \\
\hline Frozen strawberry & 105 & 63 & $61 \%$ \\
\hline
\end{tabular}

\begin{tabular}{l|l|l|l} 
Papaya & 73 & 50 & $68 \%$
\end{tabular}

Source: Foreign Agricultural Service, USDA, http://www.fas.usda.gov, per cápita Consumption Economic Research Service, USDA. 


\section{CHAPTER V}

\section{SUMMARY AND CONCLUSIONS}

\section{Summary}

Greenhouse products represent a feasible alternative for small producers compared to openfield production. Using a combination of enterprise budgeting, capital investment analysis and optimization, we found that under most of the conditions investigated the six different crops investigated are found to be profitable while, at the same time, conserving scarce land and water resources, potentially reducing production and market risk, offering consumers healthful products of good quality, that can contribute to the development of the local economy. One problem is that a larger up-front investment is often essential.

This study focused on three main areas:

1) A production and market assessment.

2) An analysis of governmental policies in Mexico and the USA, especially with respect to exports, and

3) An evaluation of credit programs for small producers.

The methodology used is as follows:

\subsubsection{Production and Market Assessment:}

- Standard economic and financial feasibility techniques such as NPV and IRR.

- Evaluation of appropriate technologies for the construction of greenhouses in the study area, and, in the process, to determine the best alternative for the installation of a greenhouse.

- Analysis of the production costs, revenues, and the break-even point using a combination of primary and secondary data. 
- Looking at cooperative or similar arrangements so that small producers can obtain better prices from their suppliers.

- Identifying opportunity windows for the target products including fruits, medicinal plants, flowers, fish or vegetables.

\subsubsection{Governmental policies and Financial opportunities}

- Will include analyzing and monitoring the prices of these products in Mexico and the USA to make the best decisions from a production viewpoint.

- Examining direct marketing strategies appropriate for the study area. Identifying export-import requirements for greenhouse products in the US and Mexico.

- Using a linear programming model, to determine optimal product mix, and, subsequently to develop a decision-support tool for small producers to facilitate producer-level decision making.

\section{Conclusions}

In the obtained results following the above methodology we can see that the product with best profit potential is green pepper, with the exception of the optimistic scenery where the tomato was the product with the best profit.

The best IRR of the examined products was found to be for green peppers and tomatoes. There are different government support programs available for SMEs; however, some of them are not available made for production under a controlled environment (i.e., greenhouses). Furthermore, for political reasons financial institution credits are hard to provide in rural areas.

In the simulation of cash flows using the LP model results made in chapter IV, it is observed that a small producer can not get a loan from any commercial institution, in a plan involving 
a 3-year loan. The bank selected was the bank with lowest interest rate and higher percentage of debt, but if the small producer could get a government program credit obtaining $50 \%$ of greenhouse construction cost price he/she would get a commercial bank loan in the most likely and optimistic scenarios.

In general diversification of production helps small producers manage risk. In terms of profit, it is possible to get higher profits from specialization. For example in Mexico there are many small vegetable shop, named "verdulerias", where the owner buys agro-products, marks them up and re-sells them. The owner of these shops, need a variety of products. In an informal study made by the author in 2001, it was found that the verdulerias are willing to buy products from small producers, including greenhouses.

Queretaro has a strategic geographical and logistic location, in the center of Mexico $(200 \mathrm{~km}$ Northwest from Mexico City). It represents Mexico's crossroads, with the two main highways that link the Northeast, West, and the Center of Mexico crossing Queretaro. The 57 Highway start in Mexico City ands end in Nuevo Laredo, Tamaulipas, on the border with the USA. Queretaro is well connected by land with many other important cities such as Mexico City, Guadalajara, Leon, Monterrey. Added to all the above mentioned location advantages a new Agro park is being built, in the Colon municipality, just 15 minutes away from Queretaro City. "Located in Queretaro, Mexico, Agropark is a new and one of a kind greenhouse park, designed and built to attract leading European and North American producers and marketers of vegetables and flowers."(www.agropark.com.mx)

Due to its environmental conditions (latitude, elevation, light levels and mild climate) Central Mexico has been recognized as one of the most interesting and competitive regions in the world, for year production. Within this region, and due to its infrastructure, labor availability, 
quality of services and living conditions, the State of Queretaro has become the entity of choice for high tech greenhouse investments. (www.agropark.com.mx)

The USA and Canada markets demand a certain range of products such as lime, avocado, strawberry, watermelon, tomato, frozen strawberries etc. (Figure 11 and table 12 show some of this products), which can be commercialized with competitive prices and marketed directly by producers to consumers.

In the study we found that some supermarket chains like Wal-Mart buy Mexican products if they are certified with the Mexico Supreme Quality certification (Mexico Calidad Suprema).

For the best greenhouse technology selection it is necessary to know some technical aspects that are mentioned in the appendix B.

The creation of cooperatives would allow the producers to offer a bigger variety of products and obtain and add value, and market products directly to restaurants and hotels to get better prices.

The Agricultural law, in its four title about rural societies, establish the organization figures, who are:

- Union of communities and Ejidos (The Ejido system is a process whereby the government promotes the use of communal land shared by the people of the community) with two or more ejidos participating.

- Rural production societies, with two or more rural producers.

- Union of rural production societies, with two or more societies of rural production.

- Rural associations of collective interest, with two or more of the following persons: "ejidos", communities, “ejidos" or communities unions, societies of rural 
productions or unions of rural production societies.(Mexican Mercantile Association)

\subsection{Limitations and Suggestions for Further Study}

It is important to note that, in this study the compatibility of the selected products in an agricultural context was not considered as a restriction (i.e., diversification was only examined from a financial, not a production, standpoint). In future studies, this should be considered as a factor to optimize the production in a greenhouse.

\subsection{Recommendations.}

\subsubsection{Trading:}

- Create cooperatives.

The UAQ has a bachelor's program to create and administrate cooperatives that allows small producers to participate in their own cooperative creation. The formation of a society of rural production is another mean that permits the producers to commercialize their products in a group setting.

- Diversify products.

There are different opportunity niches for commercialization of products for different growers. However, a potential problem is to offer a variety of products to their potential customers on a regular basis.

- Obtain certifications such as Mexico Supreme Quality (Mexico Calidad Suprema). The certification of greenhouse products in Mexico and internationally, is one of the ways to increase profits and add value to those products. 


\subsubsection{Government policies:}

- Diffusion

Different support programs exist in Mexico but they are not spread enough and the requirements are not always clear. Mexican small producers need that the government expand rural and agricultural finance without repeating the currency mistakes (such as authorizing a tractor for small producers that do not need it, or creating standard programs without verification of the real small producers needs).

- Updating

The existing programs must be update according to present day needs. For example create public policies to permit the small producers to obtain loans for working capital or specific necessities.

- Creation of new programs

The primary sector needs new support programs based on new public policies created by the government, small producers and educational institutions (following the "Sabato's triangle") to tackle real needs, and to increase access by producers

Some of the government programs provide star-up funds without requiring any repayment thus creating inequities. For example, such programs could be modified by requiring, the supported entity to return part of the investment by contributing to social or poverty alleviation programs, hiring students from government schools, donating equipment to universities providing scholarships for students, or even requiring the hiring of a minimum number of workers.

In spite of the limitations of this study, in general, it is found that, under a variety of scenarios, greenhouses can be profitable to the individual producer, can stimulate economic development in a community, and can provide society with a reliable, year-round supply of fresh crops. 


\subsection{Bibliography}

1. Alpi, A, F. Tognini, Cultivo en Invernadero, Ediciones Mundi-Prensa

2. Alford, Griffith and Cacho. 2004. A Northern Tablelands Whole-Farm Linear Program for Economic Evaluation of New Technologies at the Farm-Level.

3. Bakker, JC, G.A.P. Bot, H.Challa, N.J. Van de Braak, Greenhouses Climate Control an Integrated Control.

4. Banco Nacional de Mexico, 2008, Review of the economic situation of Mexico. (pgs 306-320)

5. Cabrera, Baker and Hildebrand. Farm problems, solutions, and extension programs for small formers in Cañete, Lima, Peru.

6. Davis H. Bangs, Jr. 1998. El plan de negocios. Guía completa para definir tu producto, servicio, mercado y financiamiento.

7. Davis and McKeown. 1986. Modelos Cuantitativos para administración.

8. Engindeniz Sait, 2002. Economic Feasibility of Organic Greenhouse Cucumber Production. The case of Menderes 367-370.

9. Greater Portland Council of Governments 2005. Feasibility Study for Agriculture Incubator.

10. Hanan, Joe, Greenhouses Advanced Technology for Protected Horticulture, CRC Press.

11. Hardin, 1983, A Linear Program Analysis of a Greenhouse, (pgs 1-6)

12. Hassan, Ahman, and Akhter. Use of linear cropping model to determine the optimum cropping pattern: A case study of Punjab.

13. Kingaman Gerald. Starting a Greenhouse Business (Part 1) Some Basic Questions.

14. Lynn Oliphanr. Low-input Greenhouses Production and Marketing of Organic Vegetable Crops. 
15. Matallana A.,MonteroJ.I., Invernaderos Diseño, Construcción y Ambientación, Ediciones Mundi-Prensa

16. Mcphee, 1984 Tomato Marketing in the Bahamas, (pgs 1-6,12-34)

17. Nelson Paul, 1998. Greenhouse Operation and Management(pgs 2-79)

18. Pérez Parra, Jerónimo, Cuadrado Gómez, Isabel Ma, Tecnologia de Invernaderos I y II Curso Superior de Especializacion Editores: FIAPA, Caja Rural de Almería

19. Plonski Gilherme A., 2000. S T Innovation and Cooperation in Latin America, 99107.

20. Serrano Cermeño Z, Construcción de Invernaderos Ediciones Mundi-Prensa

21. Thomas W.D., 2008. Alternative Greenhouse Crops. Florida Greenhouse Vegetable Production Hanbook Vol 3, 1 - 3

22. Uva, Richards. 2001. New York Greenhouse Business Summary and Financial Analysis.

23. Wayne L. Winston. 2005. Investigación de operaciones. Aplicaciones y algoritmos.

24. Wen-fei L. Uva. 1999. An analysis of the Economic Dimensions of the New York State Greenhouse Industry.

25. Weseen,Simon. 2001. The Economics of Waste Heat Utilization in Greenhouses.pgs (4-5,9-15) 


\section{APPENDICES}

\section{Appendix A}

\section{Complete Results for the LP model}

LINEAR PROGRAMMING

\section{Problem Title: LPMEdgar_opt}

Nbr. of Variables: 6

No. of Constraints: 9

INPUT GRID - LINEAR PROGRAMMING

\begin{tabular}{|c|c|c|c|c|c|c|c|c|}
\hline & x1 & $\mathrm{x} 2$ & $x 3$ & $x 4$ & $x 5$ & $x 6$ & Enter $<,>$, or $=$ & R.H.S. \\
\hline Var. Name & Tomato & Green pepper & Gerbera & Poinsettia & Strawberry & Water Melon & & \\
\hline Maximize & 2338.09 & 218.15 & 64.76 & 64.80 & 112.43 & 27.05 & & \\
\hline Constr 1 & 1.00 & 1.00 & 1.00 & 1.00 & 1.00 & 1.00 & $>=$ & 1500.00 \\
\hline Constr 2 & 1.00 & 1.00 & 1.00 & 1.00 & 1.00 & 1.00 & $<=$ & 2000.00 \\
\hline Constr 3 & 227.50 & 195.00 & 540.00 & 540.00 & 455.00 & 195.00 & $<=$ & 20000000.00 \\
\hline Constr 4 & 0.25 & 0.16 & 0.06 & 0.08 & 0.10 & 0.16 & $<=$ & 4880.00 \\
\hline Constr 5 & 236.50 & 60.00 & 180.00 & 180.00 & 42.00 & 21.00 & $<=$ & 150000.00 \\
\hline Constr 6 & 108.96 & 163.39 & 36.22 & 36.00 & 93.95 & 20.21 & $>=$ & 180000.00 \\
\hline Constr 7 & 1.00 & 1.00 & 0.00 & 0.00 & 0.00 & 0.00 & $>=$ & 100.00 \\
\hline Constr 8 & 0.00 & 0.00 & 1.00 & 1.00 & 0.00 & 0.00 & $>=$ & 100.00 \\
\hline Constr 9 & 0.00 & 0.00 & 0.00 & 0.00 & 1.00 & 1.00 & $>=$ & 100.00 \\
\hline Lower Bound & 0.00 & 0.00 & 0.00 & 0.00 & 0.00 & 0.00 & & \\
\hline Upper Bound & infinity & infinity & infinity & infinity & infinity & infinity & & \\
\hline Unrestr'd (yin)? & $\mathbf{n}$ & $\mathbf{n}$ & n & $\mathbf{n}$ & n & n & & \\
\hline
\end{tabular}

LINEAR PROGRAMMING OUTPUT SUMMARY

Title: LPMEdgar_mod
Final Iteration No.: 12

Objective Value $(\mathrm{Max})=\mathbf{4 1 2 6 2 9 . 9 0}$

\begin{tabular}{|c|c|c|c|c|}
\hline Variable & Value & Obj Coeff & Obj Val Contrib & \\
\hline x1: & 112.18 & 238.09 & 26709.25 & \\
\hline $\mathbf{x} 2$ & 1687.82 & 218.15 & 368197.65 & \\
\hline x3: & 0.00 & 64.76 & 0.00 & \\
\hline$x 4:$ & 100.00 & 64.80 & 6480.00 & \\
\hline x5: & 100.00 & 112.43 & 11243.00 & \\
\hline x6: & 0.00 & 27.05 & 0.00 & \\
\hline Constraint & RHS & Slack-ISurplus+ & & \\
\hline $1(>)$ & 1500.00 & $500.00+$ & & \\
\hline $2(<)$ & 2000.00 & 0.00 & & \\
\hline $3(<)$ & 20000000.00 & 19545854.11- & & \\
\hline $4(<)$ & 4880.00 & 4563.90 & & \\
\hline $5(<)$ & 150000.00 & 0.00 & & \\
\hline $6(>)$ & 180000.00 & $120990.97+$ & & \\
\hline $7(>)$ & 100.00 & $1700.00+$ & & \\
\hline $8(>)$ & 100.00 & 0.00 & & \\
\hline \multirow[t]{2}{*}{$9(>)$} & 100.00 & 0.00 & & \\
\hline & \multicolumn{3}{|c|}{ "**Sensitivity Analysis"** } & \\
\hline Variable & Current Obj Coeff & Min Obj Coeff & Max Obj Coeff & Reduced Cost \\
\hline x1: & 238.09 & 218.15 & $\mathbf{8 5 9 . 8 7}$ & 0.00 \\
\hline $\mathbf{x} \mathbf{2}$ & 218.15 & 124.06 & 238.09 & 0.00 \\
\hline x3: & 64.76 & -infinity & 64.80 & 0.04 \\
\hline x4: & 64.80 & 64.76 & 231.71 & 0.00 \\
\hline$\times 5:$ & 112.43 & 29.42 & 216.12 & 0.00 \\
\hline x6: & 27.05 & -infinity & 110.06 & 83.01 \\
\hline Constraint & Current RHS & Min RHS & Max RHS & Dual Price \\
\hline $1(>)$ & 1500.00 & -infinity & 2000.00 & 0.00 \\
\hline $2(<)$ & 2000.00 & 1500.00 & 2330.00 & 211.37 \\
\hline $3(<)$ & 20000000.00 & -infinity & infinity & 0.00 \\
\hline $4(<)$ & 4880.00 & 316.10 & infinity & 0.00 \\
\hline $5(<)$ & 150000.00 & 130200.00 & 447900.00 & 0.11 \\
\hline $6(>)$ & 180000.00 & -infinity & 300990.97 & 0.00 \\
\hline $7(>)$ & 100.00 & -infinity & 1800.00 & 0.00 \\
\hline $8(>)$ & 100.00 & 0.00 & 265.00 & -166.91 \\
\hline $9(>)$ & 100.00 & 0.00 & 1631.62 & -103.69 \\
\hline
\end{tabular}




\section{Moderate Scenario}

\section{LINEAR PROGRAMMING}

Problem Title: $\quad$ IPMEdgar_mod
Nbr. of Variables: 6
No. of Constraints: 9

Editing Grid:

$\gg$ Click Maximize(Minimize)-cell to change it to Minimize(Maximize) $\gg$ To DELETE, INSERT, COPY, or PASTE a column(row), click heading cell of target column(row), then irvoke pull-down EditGrid menu

$\gg$ For INSERT mode, a single(double) click of target row/column will place new row/column after(before) target row/column.

\begin{tabular}{|c|c|c|c|c|c|c|c|c|}
\hline & x1 & $x 2$ & $x^{3}$ & $x 4$ & $x 5$ & $x 6$ & Enter $<,>$, or $=$ & R.H.S. \\
\hline \multicolumn{9}{|l|}{ Var. Name } \\
\hline Maximize & 108.96 & 163.39 & 36.22 & 36.00 & 93.95 & 20.21 & & \\
\hline Constr 1 & 1.00 & 1.00 & 1.00 & 1.00 & 1.00 & 1.00 & $>=$ & 1500.00 \\
\hline Constr 2 & 1.00 & 1.00 & 1.00 & 1.00 & 1.00 & 1.00 & $<=$ & 2000.00 \\
\hline Constr 3 & 227.50 & 195.00 & 540.00 & 540.00 & 455.00 & 195.00 & $<=$ & 20000000.00 \\
\hline Constr 4 & 0.25 & 0.16 & 0.06 & 0.08 & 0.10 & 0.16 & $<=$ & 4880.00 \\
\hline Constr 5 & 236.50 & 60.00 & 180.00 & 180.00 & 42.00 & 21.00 & $<=$ & 150000.00 \\
\hline Constr 6 & 108.96 & 163.39 & 36.22 & 36.00 & 93.95 & 20.21 & $>=$ & 180000.00 \\
\hline Constr 7 & 1.00 & 1.00 & 0.00 & 0.00 & 0.00 & 0.00 & $>=$ & 100.00 \\
\hline Constr 8 & 0.00 & 0.00 & 1.00 & 1.00 & 0.00 & 0.00 & $>=$ & 100.00 \\
\hline Constr 9 & 0.00 & 0.00 & 0.00 & 0.00 & 1.00 & 1.00 & $>=$ & 100.00 \\
\hline Lower Bound & 0.00 & 0.00 & 0.00 & 0.00 & 0.00 & 0.00 & & \\
\hline Upper Bound & infinity & infinity & infinity & infinity & infinity & infinity & & \\
\hline Unrestr'd (yin)? & $\mathbf{n}$ & $\mathbf{n}$ & $n$ & $n$ & $\mathbf{n}$ & $\mathrm{n}$ & & \\
\hline
\end{tabular}

\section{LINEAR PROGRAMMING OUTPUT SUMMARY}

Title: LPMEdgar_mod

Final Iteration No.: 12

Objective Value $($ Max) $=307119.00$

\begin{tabular}{|c|c|c|c|c|}
\hline Variable & Value & Obj Coeff & Obj Val Contrib & \\
\hline x1: & 0.00 & 108.96 & 0.00 & \\
\hline $\mathbf{x} 2:$ & 1800.00 & 163.39 & 294102.00 & \\
\hline x3: & 100.00 & 36.22 & 3622.00 & \\
\hline x4: & 0.00 & 36.00 & 0.00 & \\
\hline x5: & 100.00 & 93.95 & 9395.00 & \\
\hline x6: & 0.00 & 20.21 & 0.00 & \\
\hline Constraint & RHS & Slack-/Surplus+ & & \\
\hline $1(>)$ & 1500.00 & $500.00+$ & & \\
\hline $2(<)$ & 2000.00 & 0.00 & & \\
\hline $3(4)$ & 20000000.00 & 19549500.00 & & \\
\hline $4(<)$ & 4880.00 & 4576.00 & & \\
\hline $5(<)$ & 150000.00 & 19800.00 & & \\
\hline $6(>)$ & 180000.00 & $127119.00+$ & & \\
\hline $7(>)$ & 100.00 & $1700.00+$ & & \\
\hline $8(>)$ & 100.00 & 0.00 & & \\
\hline \multirow[t]{2}{*}{$9(>)$} & 100.00 & 0.00 & & \\
\hline & \multicolumn{4}{|c|}{ "**Sensitivity Analysis"** } \\
\hline Variable & Current Obj Coeff & Min Obj Coeff & Max Obj Coeff & Reduced Cost \\
\hline x1: & 108.96 & -infinity & 163.39 & $\mathbf{5 4 . 4 3}$ \\
\hline$x 2:$ & 163.39 & 108.96 & infinity & 0.00 \\
\hline x3: & 36.22 & 36.00 & 163.39 & 0.00 \\
\hline x4: & 36.00 & -infinity & 36.22 & 0.22 \\
\hline x5: & 93.95 & 20.21 & 163.39 & 0.00 \\
\hline x6: & 20.21 & -infinity & 93.95 & 73.74 \\
\hline Constraint & Current RHS & Min RHS & Max RHS & Dual Price \\
\hline $1(\geqslant)$ & 1500.00 & -infinity & 2000.00 & 0.00 \\
\hline $2(<)$ & 2000.00 & 1500.00 & 2330.00 & 163.39 \\
\hline $3(<)$ & 20000000.00 & -intinity & infinity & 0.00 \\
\hline $4(<)$ & 4880.00 & 304.00 & infinity & 0.00 \\
\hline $5(<)$ & 150000.00 & 130200.00 & infinity & 0.00 \\
\hline $6(>)$ & 180000.00 & -infinity & 307119.00 & 0.00 \\
\hline $7(>)$ & 100.00 & -infinity & 1800.00 & 0.00 \\
\hline $8(>)$ & 100.00 & 0.00 & 265.00 & -127.17 \\
\hline $9(>)$ & 100.00 & 0.00 & 1800.00 & -69.44 \\
\hline
\end{tabular}


Sensitivity Analysis

\begin{tabular}{|c|c|c|c|c|c|c|c|c|}
\hline \multicolumn{9}{|c|}{ LINEAR PROGRAMMING } \\
\hline \multicolumn{4}{|c|}{$\begin{array}{l}\text { Problem Title: } \quad \text { SA_LPM_opt } \\
\text { Nbr. of Variables: } 6 \\
\text { No. of Constraints: } 9\end{array}$} & \multicolumn{5}{|c|}{ 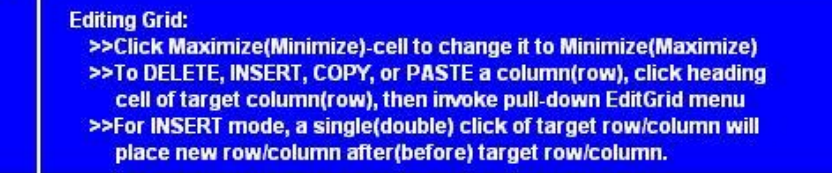 } \\
\hline \multicolumn{9}{|c|}{ INPUT GRID - LINEAR PROGRAMMING } \\
\hline & $x 1$ & $x 2$ & $x 3$ & $x 4$ & $x 5$ & $\mathbf{x 6}$ & Enter $<,>$, or $=$ & R.H.S. \\
\hline \multicolumn{9}{|l|}{ Var. Name } \\
\hline Maximize & 238.09 & 218.15 & 64.76 & 64.80 & 112.43 & 27.05 & & \\
\hline Constr 1 & 1.00 & 1.00 & 1.00 & 1.00 & 1.00 & 1.00 & $>=$ & 1500.00 \\
\hline Constr 2 & 1.00 & 1.00 & 1.00 & 1.00 & 1.00 & 1.00 & $<$ & 2000.00 \\
\hline Constr 3 & 227.50 & 195.00 & 540.00 & 540.00 & 455.00 & 195.00 & $\ll$ & 20000000.00 \\
\hline Constr 4 & 0.25 & 0.16 & 0.06 & 0.08 & 0.10 & 0.16 & $<=$ & 4880.00 \\
\hline Constr 5 & 236.50 & 60.00 & 180.00 & 180.00 & 42.00 & 21.00 & $<$ & 100000.00 \\
\hline Constr 6 & 108.96 & 163.39 & 36.22 & 36.00 & 93.95 & 20.21 & $>=$ & 180000.00 \\
\hline Constr 7 & 1.00 & 1.00 & 0.00 & 0.00 & 0.00 & 0.00 & $>=$ & 100.00 \\
\hline Constr 8 & 0.00 & 0.00 & 1.00 & 1.00 & 0.00 & 0.00 & $>=$ & 100.00 \\
\hline Constr 9 & 0.00 & 0.00 & 0.00 & 0.00 & 1.00 & 1.00 & $>=$ & 100.00 \\
\hline Lower Bound & 0.00 & 0.00 & 0.00 & 0.00 & 0.00 & 0.00 & & \\
\hline Upper Bound & infinity & infinity & infinity & infinity & infinity & infinity & & \\
\hline Unrestr'd (y/n)? & $\mathrm{n}$ & n & $\mathrm{n}$ & $\mathbf{n}$ & $\mathbf{n}$ & $n$ & & \\
\hline
\end{tabular}

LINEAR PROGRAMMING OUTPUT SUMMARY

Title: SA_LPM_opt

Final Iteration No.: 12

Objective Value (Max) $=300504.86$

\begin{tabular}{|c|c|c|c|c|}
\hline Variable & Value & Obj Coeff & Obj Val Contrib & \\
\hline x1: & 0.00 & 238.09 & 0.00 & \\
\hline$\times 2:$ & 1300.00 & 218.15 & 283595.00 & \\
\hline x3: & 0.00 & 64.76 & 0.00 & \\
\hline $\mathbf{x 4 :}$ & 100.00 & 64.80 & 6480.00 & \\
\hline$x 5:$ & 90.48 & 112.43 & 10172.24 & \\
\hline$x 6:$ & 9.52 & 27.05 & 257.62 & \\
\hline Constraint & RHS & Slack-/Surplus+ & & \\
\hline $1(\geqslant)$ & 1500.00 & 0.00 & & \\
\hline $2(<)$ & 2000.00 & 500.00 & & \\
\hline $3(<)$ & 20000000.00 & 19649476.19- & & \\
\hline $4(<)$ & 4880.00 & 4653.43- & & \\
\hline $5(<)$ & 100000.00 & 0.00 & & \\
\hline $6(>)$ & 180000.00 & 44699.71+ & & \\
\hline $7(\geqslant)$ & 100.00 & $1200.00+$ & & \\
\hline $8(>)$ & 100.00 & 0.00 & & \\
\hline \multirow[t]{2}{*}{$9(>)$} & 100.00 & 0.00 & & \\
\hline & \multicolumn{4}{|c|}{ "* Sensitivity Analysis"** } \\
\hline Variable & Current Obj Coeff & Min Obj Coeff & Max Obj Coeff & Reduced Cost \\
\hline x1: & 238.09 & -infinity & 935.75 & 697.66 \\
\hline $\mathbf{x z}:$ & 218.15 & 185.61 & 243.94 & 0.00 \\
\hline x3: & 64.76 & -infinity & 64.80 & 0.04 \\
\hline x4: & 64.80 & 64.76 & 706.04 & 0.00 \\
\hline X5: & T12.43 & 103.40 & 129.95 & 0.00 \\
\hline x6: & 27.05 & -10.91 & 36.08 & 0.00 \\
\hline Constraint & Current RHS & Min RHS & Max RHS & Dual Price \\
\hline $1(>)$ & 1500.00 & 1496.67 & 1531.67 & -25.79 \\
\hline $2(<)$ & 2000.00 & 1500.00 & infinity & 0.00 \\
\hline $3(<)$ & 20000000.00 & -infinity & infinity & 0.00 \\
\hline $4(<)$ & 4880.00 & 226.57 & infinity & 0.00 \\
\hline $5(<)$ & 100000.00 & 98100.00 & 100200.00 & 4.07 \\
\hline $6(>)$ & 180000.00 & -infinity & 224699.71 & 0.00 \\
\hline $7(>)$ & 100.00 & -infinity & 1300.00 & 0.00 \\
\hline $8(>)$ & 100.00 & 98.33 & 115.83 & -641.24 \\
\hline $9(>)$ & 100.00 & 51.28 & 111.11 & -32.54 \\
\hline
\end{tabular}


Pesimistic

LINEAR PROGRAMMING

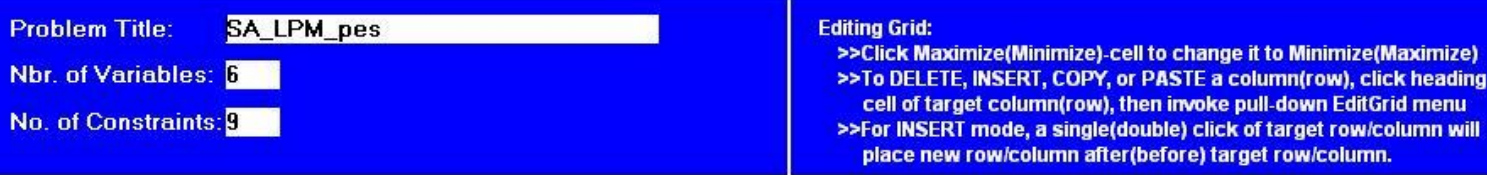

INPUT GRID - LINEAR PROGRAMMING

\begin{tabular}{|c|c|c|c|c|c|c|c|c|}
\hline & $x 1$ & $x 2$ & $x 3$ & $x 4$ & $\times 5$ & $\mathrm{x} 6$ & Enter $<$, $>$, or $=$ & R.H.S. \\
\hline \multicolumn{9}{|l|}{ Var. Name } \\
\hline Maximize & -20.17 & 108.64 & 7.67 & 0.00 & 75.48 & 14.57 & & \\
\hline Constr 1 & 1.00 & 1.00 & 1.00 & 1.00 & 1.00 & 1.00 & $>=$ & 1500.00 \\
\hline Constr 2 & 1.00 & 1.00 & 1.00 & 1.00 & 1.00 & 1.00 & $<=$ & 2000.00 \\
\hline Constr 3 & 227.50 & 195.00 & 540.00 & 540.00 & 455.00 & 195.00 & $<=$ & 20000000.00 \\
\hline Constr 4 & 0.25 & 0.16 & 0.06 & 0.08 & 0.10 & 0.16 & $<=$ & 4880.00 \\
\hline Constr 5 & 236.50 & 60.00 & 180.00 & 180.00 & 42.00 & 21.00 & $<=$ & 100000.00 \\
\hline Constr 6 & 108.96 & 163.39 & 36.22 & 36.00 & 93.95 & 20.21 & $>=$ & 180000.00 \\
\hline Constr 7 & 1.00 & 1.00 & 0.00 & 0.00 & 0.00 & 0.00 & $>=$ & 100.00 \\
\hline Constr 8 & 0.00 & 0.00 & 1.00 & 1.00 & 0.00 & 0.00 & $>=$ & 100.00 \\
\hline Constr 9 & 0.00 & 0.00 & 0.00 & 0.00 & 1.00 & 1.00 & $>=$ & 100.00 \\
\hline Lower Bound & 0.00 & 0.00 & 0.00 & 0.00 & 0.00 & 0.00 & & \\
\hline Upper Bound & infinity & infinity & infinity & infinity & infinity & infinity & & \\
\hline Unrestr'd (y/n)? & $\mathbf{n}$ & $n$ & $\mathbf{n}$ & n & $n$ & $\mathbf{n}$ & & \\
\hline
\end{tabular}

\section{LINEAR PROGRAMMING OUTPUT SUMMARY}

Title: SA_LPM_pes

Final Iteration No.: 14

Objective Value (Max) $=\mathbf{1 4 9 1 7 8 . 5 6}$

\begin{tabular}{|c|c|c|c|c|}
\hline Variable & Value & Obj Coeff & Obj Val Contrib & \\
\hline x1: & 0.00 & -20.17 & 0.00 & \\
\hline x: & 1288.89 & 108.64 & 140024.89 & \\
\hline x3: & 100.00 & 7.67 & 767.00 & \\
\hline$x 4:$ & 0.00 & 0.00 & 0.00 & \\
\hline$x 5:$ & 111.11 & 75.48 & 8386.67 & \\
\hline x6: & 0.00 & 14.57 & 0.00 & \\
\hline Constraint & RHS & Slack-/Surplus+ + & & \\
\hline $1(>)$ & 1500.00 & 0.00 & & \\
\hline $2(<)$ & 2000.00 & 500.00 & & \\
\hline $3(4)$ & 20000000.00 & 19644111.11. & & \\
\hline $4(<)$ & 4880.00 & 4656.67 & & \\
\hline $5(4)$ & 100000.00 & 0.00 & & \\
\hline $6(>)$ & 180000.00 & $44652.44+$ & & \\
\hline $7(2)$ & 100.00 & $1188.89+$ & & \\
\hline $8(\gg)$ & 100.00 & 0.00 & & \\
\hline \multirow[t]{2}{*}{$9(>)$} & 100.00 & $11.11+$ & & \\
\hline & \multicolumn{3}{|c|}{ "*Sensitivity Analysis"** } & \\
\hline Variable & Current Obj Coeff & Min Obj Coeff & Max Obj Coeff & Reduced Cost \\
\hline x1: & -20.17 & -infinity & 433.79 & 453.96 \\
\hline$x 2:$ & 108.64 & 107.83 & 127.69 & 0.00 \\
\hline x3: & 7.67 & 0.00 & 329.71 & 0.00 \\
\hline$x 4:$ & 0.00 & -infinity & 7.67 & 7.67 \\
\hline$\times 5:$ & 75.48 & 65.22 & 76.05 & 0.00 \\
\hline$x 6$ & 14.57 & -infinity & 36.79 & 22.22 \\
\hline Constraint & Current RHS & Min RHS & Max RHS & Dual Price \\
\hline $1(>)$ & 1500.00 & 1496.67 & 2000.00 & -1.89 \\
\hline $2(4)$ & 2000.00 & 1500.00 & infinity & 0.00 \\
\hline $3(4)$ & 20000000.00 & -infinity & infinity & 0.00 \\
\hline $4(5)$ & 4880.00 & 223.33 & infinity & 0.00 \\
\hline $5(4)$ & 100000.00 & 88425.35 & 100200.00 & 1.84 \\
\hline $6(>)$ & 180000.00 & -infinity & 224652.44 & 0.00 \\
\hline $7(\geqslant)$ & 100.00 & -infinity & 1288.89 & 0.00 \\
\hline $8(>)$ & 100.00 & 98.33 & 175.67 & -322.04 \\
\hline $9(\geqslant)$ & 100.00 & -infinity & 111.11 & 0.00 \\
\hline
\end{tabular}


Moderate

LINEAR PROGRAMMING

\begin{tabular}{l|l} 
Problem Title: SA_LPM_mod & $\begin{array}{l}\text { Editing Grid: } \\
\text { >Click Maximize(Minimize)-cell to change it to Minimize(Maximize) } \\
>>\text { To DELETE, INSERT, COPY, or PASTE a column(row), click heading } \\
\text { cell of target column(row), then irvoke pull-down EditGrid menu } \\
\text { Nbr. of Variables: } 6\end{array}$ \\
$\begin{array}{l}\text { Nor INSERT mode, a single(double) click of target row/column will } \\
\text { place new row/column after(before) target row/column. }\end{array}$
\end{tabular}

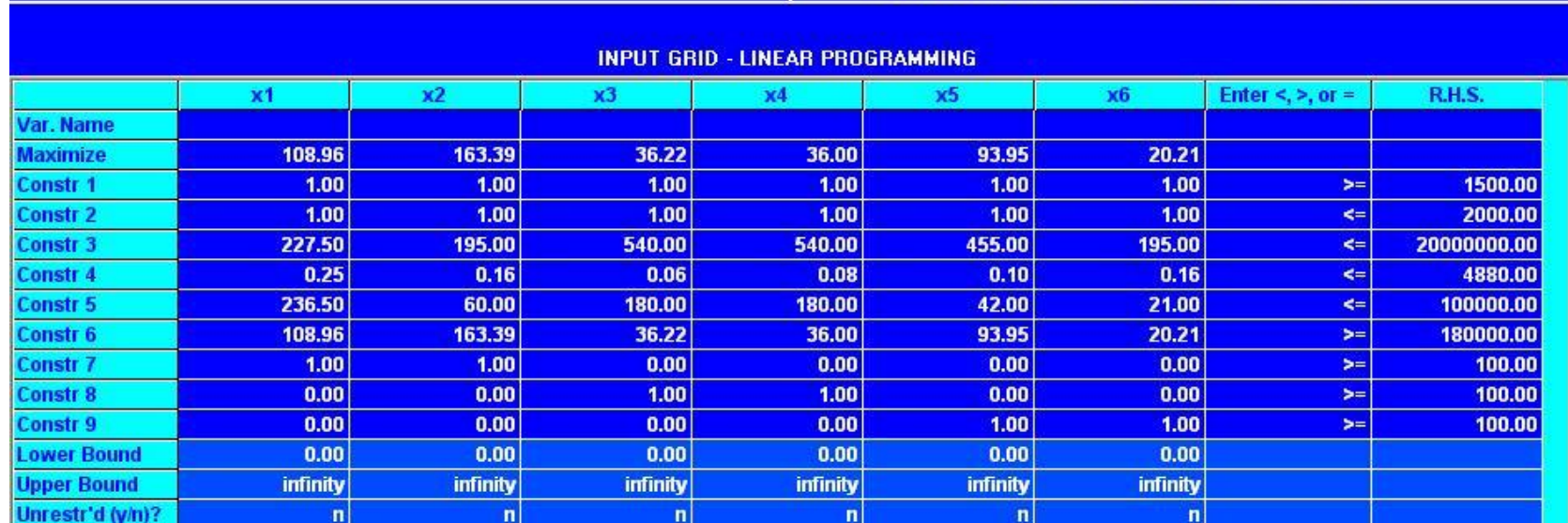

LINEAR PROGRAMMING OUTPUT SUMMARY

\begin{tabular}{|c|c|c|c|c|}
\hline \multicolumn{5}{|c|}{$\begin{array}{l}\text { Title: SA_LPM_mod } \\
\text { Final Iteration No.: } 12 \\
\text { Objective Value (Max) }=224721.71\end{array}$} \\
\hline & & All Iterations & Printer & \\
\hline Variable & Value & Obj Coeff & Obj Val Contrib & \\
\hline x1: & 0.00 & 108.96 & 0.00 & \\
\hline x2: & 1300.00 & 163.39 & 212407.00 & \\
\hline x3: & 100.00 & 36.22 & 3622.00 & \\
\hline x4: & 0.00 & 36.00 & 0.00 & \\
\hline x5: & 90.48 & 93.95 & 8500.24 & \\
\hline x6: & 9.52 & 20.21 & 192.48 & \\
\hline Constraint & RHS & Slack-ISurplus+ & & \\
\hline $1(\geqslant)$ & 1500.00 & 0.00 & & \\
\hline $2(<)$ & 2000.00 & 500.00 & & \\
\hline $3(<)$ & 20000000.00 & 19649476.19 & & \\
\hline $4(<)$ & 4880.00 & 4655.43 & & \\
\hline $5(<)$ & 100000.00 & 0.00 & & \\
\hline $6(>)$ & 180000.00 & $44721.71+$ & & \\
\hline $7(>)$ & 100.00 & $1200.00+$ & & \\
\hline $8(>)$ & 100.00 & 0.00 & & \\
\hline \multirow[t]{2}{*}{$9(\gg)$} & 100.00 & 0.00 & & \\
\hline & \multicolumn{4}{|c|}{ **Sensitivity Analysis"** } \\
\hline Variable & Current Obj Coeff & Min Obj Coeff & Max Obj Coeff & Reduced Cost \\
\hline x1: & 108.96 & -infinity & 783.16 & 674.20 \\
\hline x2: & 163.39 & 157.16 & 210.69 & 0.00 \\
\hline x3: & 36.22 & 36.00 & 584.76 & 0.00 \\
\hline x4: & 36.00 & -intinity & 36.22 & 0.22 \\
\hline$\times 5:$ & 93.95 & 77.40 & 97.31 & 0.00 \\
\hline x6: & 20.21 & 12.94 & 36.76 & 0.00 \\
\hline Constraint & Current RHS & Min RHS & Max RHS & Dual Price \\
\hline $1(>)$ & 1500.00 & 1496.67 & 1531.67 & -47.30 \\
\hline $2(<)$ & 2000.00 & 1500.00 & infinity & 0.00 \\
\hline $3(<)$ & 20000000.00 & -infinity & infinity & 0.00 \\
\hline $4(<)$ & 4880.00 & 224.57 & infinity & 0.00 \\
\hline $5(<)$ & 100000.00 & 98100.00 & 100200.00 & 3.51 \\
\hline $6(>)$ & 180000.00 & -infinity & 224721.71 & 0.00 \\
\hline $7(>)$ & 100.00 & -infinity & 1300.00 & 0.00 \\
\hline $8(7)$ & 100.00 & 98.33 & 115.83 & -548.54 \\
\hline $9(>)$ & 100.00 & 51.28 & 111.11 & -6.23 \\
\hline
\end{tabular}




\section{Appendix B}

Complete Project Analysis for each crop choice in a 2000sqm greenhouse.

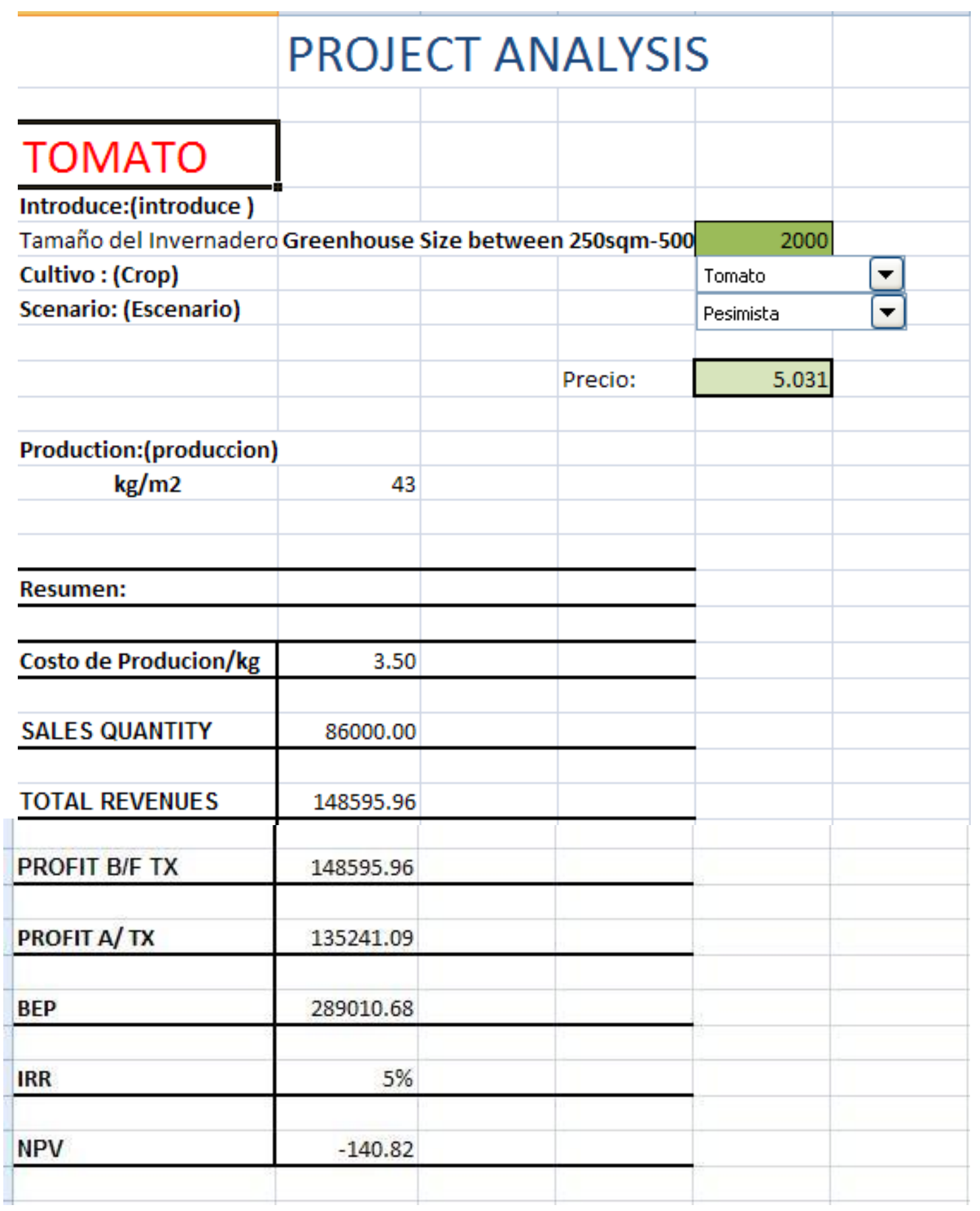




\section{PROJECT ANALYSIS}

\section{TOMATO}

Introduce:(introduce )

Tamaño del Invernadero Greenhouse Size between 250 sqm-500 Cultivo : (Crop)

Scenario: (Escenario)

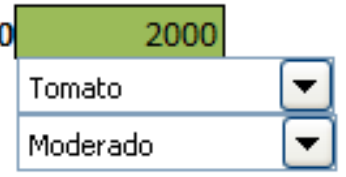

Precio:

Production:(produccion)

$\mathrm{kg} / \mathrm{m} 2$

43

Resumen:

\begin{tabular}{l|c}
\hline Costo de Producion/kg & 3.50 \\
\hline SALES QUANTITY & 86000.00 \\
\hline TOTAL REVENUES & 422349.44 \\
\hline PROFIT B/F TX & 422349.44 \\
\hline PROFIT A/ TX & 332343.60 \\
\hline BEP & \\
\hline & 170520.34 \\
\hline IRR & \\
\hline NPV & $29 \%$ \\
\hline
\end{tabular}




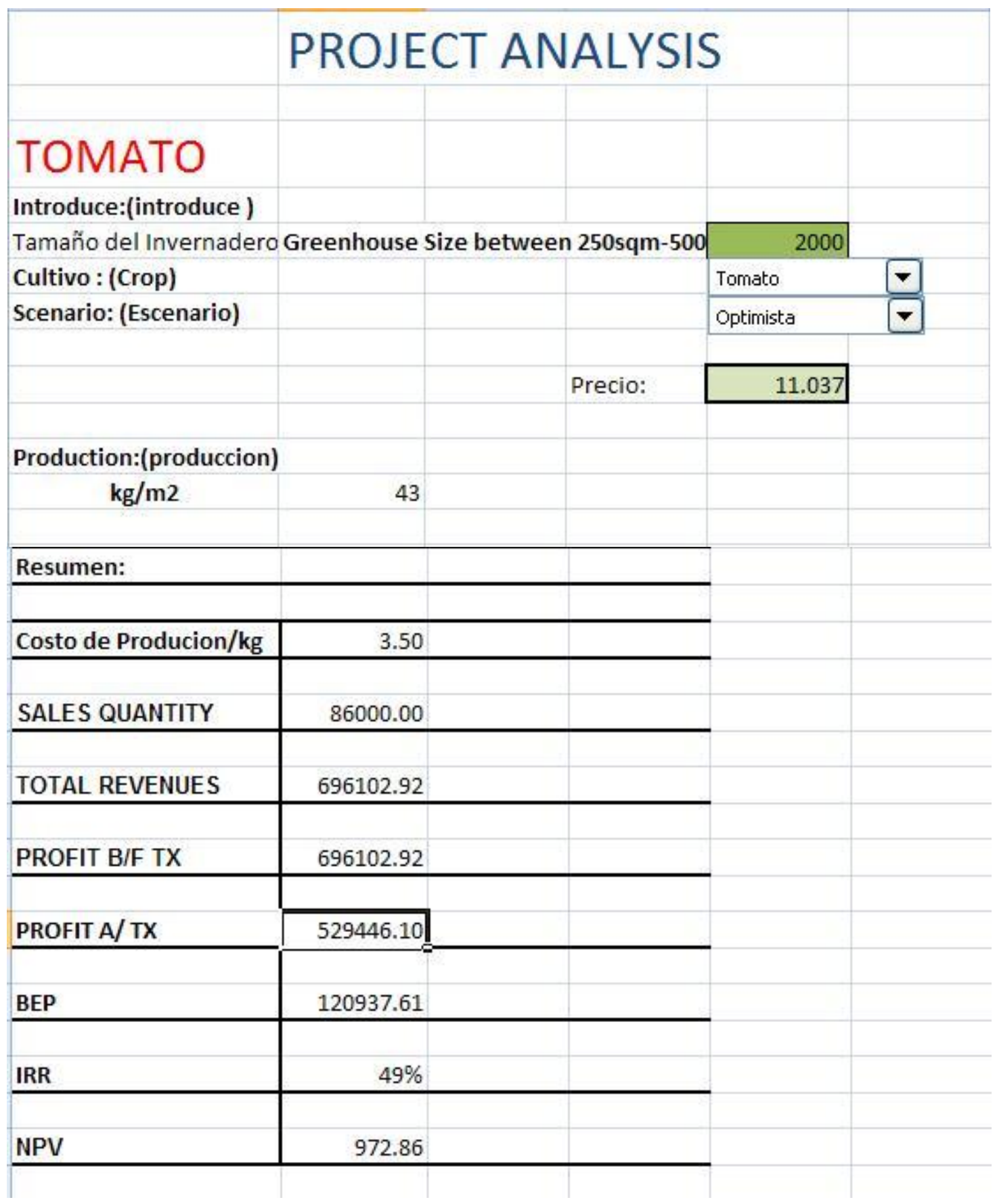




\section{PROJECT ANALYSIS}

\section{GREENPEPPER}

Introduce:(introduce )

Tamaño del Invernadero Greenhouse Size between 250 sqm-500 Crop: (Cultivo)

Scenario: (Escenario)

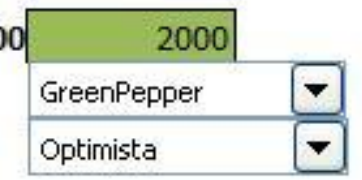

Precio:

Production:(produccion)

$\mathrm{kg} / \mathrm{m} 2$

12

\begin{tabular}{l|c}
\hline \multicolumn{2}{l}{ Resumen: } \\
\hline Costo de Producion/kg & 5.00 \\
\hline SALES QUANTITY & 24000.00 \\
\hline TOTAL REVENUES & 435896.00 \\
\hline PROFIT B/F TX & 435896.00 \\
\hline PROFIT A/ TX & 131613.60 \\
\hline BEP & \\
\hline & 55586.12 \\
\hline IRR & $41 \%$ \\
\hline NPV & 800.38 \\
\hline
\end{tabular}




\section{PROJECT ANALYSIS}

\section{GREENPEPPER}

Introduce:(introduce)

Tamaño del Invernadero Greenhouse Size between $250 \mathrm{sqm}-500$ Crop: (Cultivo)

Scenario: (Escenario)

\begin{tabular}{|l|}
\hline 2000 \\
\hline GreenPepper \\
\hline Moderado \\
\hline
\end{tabular}

Precio:

18.616

Production:(produccion)

$\mathrm{kg} / \mathrm{m} 2$

12

\begin{tabular}{l|c}
\hline \multicolumn{2}{l}{ Resumen: } \\
\hline Costo de Producion/kg & 5.00 \\
\hline SALES QUANTITY & 24000.00 \\
\hline TOTAL REVENUES & 326384.00 \\
\hline PROFIT B/F TX & 326384.00 \\
\hline PROFIT A/TX & \\
\hline BEP & 93284.40 \\
\hline IRR & 69750.66 \\
\hline NPV & $31 \%$ \\
\hline
\end{tabular}




\section{PROJECT ANALYSIS}

\section{GREENPEPPER}

Introduce:(introduce)

Tamaño del Invernadero Greenhouse Size between 250 sqm-500

Crop : (Cultivo)

Scenario: (Escenario)

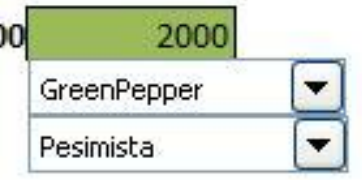

Precio:

14.053

Production:(produccion)

$\mathrm{kg} / \mathrm{m} 2$

12

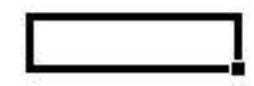

\begin{tabular}{l|c}
\hline \multicolumn{2}{l}{ Resumen: } \\
\hline Costo de Producion/kg & 5.00 \\
\hline SALES QUANTITY & 24000.00 \\
\hline TOTAL REVENUES & 216872.00 \\
\hline PROFIT B/F TX & 216872.00 \\
\hline PROFIT A/ TX & \\
\hline BEP & 54955.20 \\
\hline IRR & 93602.65 \\
\hline
\end{tabular}




\section{PROJECT ANALYSIS}

\section{GERBERA}

Introduce:(introduce)

Tamaño del Invernadero Greenhouse Size between 250 sqm-500 Crop : (Cultivo)

Scenario: (Escenario)

\begin{tabular}{|l|}
\hline 2000 \\
\hline Gerbera \\
\hline Pesimista \\
\hline
\end{tabular}

Precio:

5.213

Production:(produccion)

$\mathrm{kg} / \mathrm{m} 2$

36

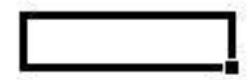

\begin{tabular}{l|c}
\hline \multicolumn{2}{l}{ Resumen: } \\
\hline Costo de Producion/kg & 5.00 \\
\hline SALES QUANTITY & 24000.00 \\
\hline TOTAL REVENUES & 216872.00 \\
\hline PROFIT B/F TX & \\
\hline PROFIT A/TX & 216872.00 \\
\hline BEP & 54955.20 \\
\hline IRR & \\
\hline
\end{tabular}




\section{PROJECT ANALYSIS}

\section{GREENPEPPER}

Introduce:(introduce)

Tamaño del Invernadero Greenhouse Size between $250 \mathrm{sqm}-500$ Crop: (Cultivo)

Scenario: (Escenario)

\begin{tabular}{|l|}
\hline 2000 \\
\hline GreenPepper \\
\hline Moderado \\
\hline
\end{tabular}

Precio:

18.616

Production:(produccion)

$\mathrm{kg} / \mathrm{m} 2$

12

\begin{tabular}{l|c}
\hline \multicolumn{2}{l}{ Resumen: } \\
\hline Costo de Producion/kg & 5.00 \\
\hline SALES QUANTITY & 24000.00 \\
\hline TOTAL REVENUES & 326384.00 \\
\hline PROFIT B/F TX & 326384.00 \\
\hline PROFIT A/TX & \\
\hline BEP & 93284.40 \\
\hline IRR & 69750.66 \\
\hline NPV & $31 \%$ \\
\hline
\end{tabular}




\section{PROJECT ANALYSIS}

\section{GERBERA}

Introduce:(introduce)

Tamaño del Invernadero Greenhouse Size between $250 \mathrm{sqm}-500$

Crop : (Cultivo)

Scenario: (Escenario)

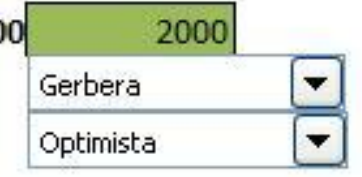

Precio:

6.799

Production:(produccion)

$\mathrm{kg} / \mathrm{m} 2$

36

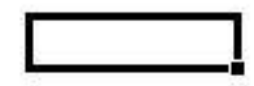

Resumen:

\begin{tabular}{l|c}
\hline Costo de Producion/kg & 2.50 \\
\hline SALES QUANTITY & 72000.00 \\
\hline TOTAL REVENUES & 308928.00 \\
\hline PROFIT B/F TX & 308928.00 \\
\hline PROFIT A/ TX & 87174.80 \\
\hline BEP & 205102.45 \\
\hline IRR & \\
\hline NPV & $27 \%$ \\
\hline
\end{tabular}




\section{PROJECT ANALYSIS}

\section{NOCHE BUENA}

Introduce:(introduce )

Tamaño del Invernadero Greenhouse Size between 250sqm-500 Cultivo: (Crop)

Escenario: (Scenario)

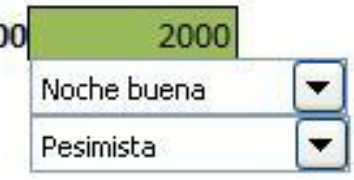

Precio:

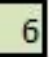

Production:(produccion)

$\mathrm{kg} / \mathrm{m} 2$

36

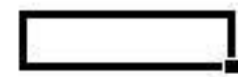

\begin{tabular}{l|c}
\hline \multicolumn{2}{l}{ Resumen: } \\
\hline Costo de Producion/kg & 3.00 \\
\hline SALES QUANTITY & 72000.00 \\
\hline TOTAL REVENUES & 212880.00 \\
\hline PROFIT B/F TX & 212880.00 \\
\hline PROFIT A/TX & \\
\hline BEP & 74508.00 \\
\hline IRR & 236077.32 \\
\hline
\end{tabular}




\section{PROJECT ANALYSIS}

\section{NOCHE BUENA}

Introduce:(introduce )

Tamaño del Invernadero Greenhouse Size between 250 sqm-500 Cultivo : (Crop)

Escenario: (Scenario)

\begin{tabular}{|l|}
\hline Noche buena \\
\hline Moderado \\
\hline
\end{tabular}

Precio:

7.03

Production:(produccion)

$\mathrm{kg} / \mathrm{m} 2$

36

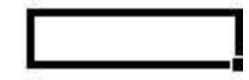

\begin{tabular}{|c|c|}
\hline \multicolumn{2}{|l|}{ Resumen: } \\
\hline Costo de Producion $/ \mathrm{kg}$ & 3.00 \\
\hline SALES QUANTITY & 72000.00 \\
\hline TOTAL REVENUES & 287040.00 \\
\hline PROFIT B/F TX & 287040.00 \\
\hline PROFIT A/TX & 100464.00 \\
\hline BEP & 197606.59 \\
\hline IRR & $24 \%$ \\
\hline NPV & 467.65 \\
\hline
\end{tabular}




\section{PROJECT ANALYSIS}

\section{NOCHE BUENA}

Introduce:(introduce)

Tamaño del Invernadero Greenhouse Size between $250 \mathrm{sqm}-500$

Cultivo : (Crop)

Escenario: (Scenario)

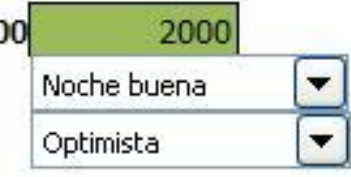

Precio:

Production:(produccion)

$\mathrm{kg} / \mathrm{m} 2$

36

\begin{tabular}{l|c}
\hline \multicolumn{2}{l}{ Resumen: } \\
\hline \multicolumn{2}{|c}{3.00} \\
\hline Costo de Producion/kg & \\
\hline SALES QUANTITY & 72000.00 \\
\hline & \\
\cline { 2 - 2 } TOTAL REVENUES & 356880.00 \\
\hline PROFIT B/F TX & 356880.00 \\
\hline & \\
PROFIT A/ TX & 124908.00 \\
\hline & \\
BEP & $30 \%$ \\
\hline & \\
\hline IRR & 627.07 \\
\hline NPV &
\end{tabular}




\section{PROJECT ANALYSIS}

\section{STRAWBERRY}

\section{Introduce:(introduce)}

Tamaño del Invernadero Greenhouse Size between 250sqm-500 Cultivo : (Crop)

Escenario: (Scenario)

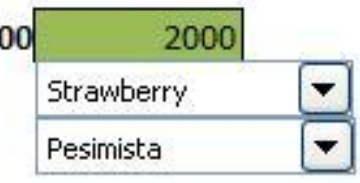

Precio:

Production:(produccion)

$\mathrm{kg} / \mathrm{m} 2$

7

\begin{tabular}{l|c}
\hline \multicolumn{2}{l}{ Resumen: } \\
\hline Costo de Producion/kg & 6.00 \\
\hline SALES QUANTITY & 14000.00 \\
\hline TOTAL REVENUES & 157082.00 \\
\hline PROFIT B/F TX & 157082.00 \\
\hline PROFIT A/TX & 39278.70 \\
\hline BEP & \\
\hline & \\
IRR & $13 \%$ \\
\hline
\end{tabular}




\section{PROJECT ANALYSIS}

\section{STRAWBERRY}

\section{Introduce:(introduce)}

Tamaño del Invernadero Greenhouse Size between 250sqm-500 Cultivo : (Crop)

Escenario: (Scenario)

\begin{tabular}{|l|}
\hline \multicolumn{2}{|c|}{2000} \\
\hline Strawberry \\
\hline Moderado \\
\hline
\end{tabular}

Precio:

Production:(produccion)

$\mathrm{kg} / \mathrm{m} 2$

7

\begin{tabular}{l|c}
\hline \multicolumn{2}{l}{ Resumen: } \\
\hline Costo de Producion/kg & 6.00 \\
\hline SALES QUANTITY & 14000.00 \\
\hline TOTAL REVENUES & 194028.00 \\
\hline PROFIT B/F TX & 194028.00 \\
\hline PROFIT A/ TX & \\
\hline BEP & 52209.80 \\
\hline IRR & 66746.33 \\
\hline NPV & $17 \%$ \\
\hline
\end{tabular}




\section{PROJECT ANALYSIS}

\section{STRAWBERRY}

Introduce:(introduce)

Tamaño del Invernadero Greenhouse Size between 250 sqm-500

Cultivo : (Crop)

Escenario: (Scenario)

\begin{tabular}{|l|}
\hline Strawberry \\
\hline Optimista \\
\hline
\end{tabular}

Precio:

22.061

Production:(produccion)

$\mathrm{kg} / \mathrm{m} 2$

7

\begin{tabular}{|c|c|}
\hline Resumen: & \\
\hline Costo de Producion/kg & 6.00 \\
\hline SALES QUANTITY & 14000.00 \\
\hline TOTAL REVENUES & 230974.00 \\
\hline PROFIT B/F TX & 230974.00 \\
\hline PROFIT A/TX & 65140.90 \\
\hline BEP & 58496.68 \\
\hline IRR & $20 \%$ \\
\hline NPV & 288.90 \\
\hline
\end{tabular}




\section{PROJECT ANALYSIS}

\section{WATER MELON}

\section{Introduce:(introduce)}

Tamaño del Invernadero Greenhouse Size between 250 sqm-500 Cultivo : (Crop)

Escenario: (Scenario)

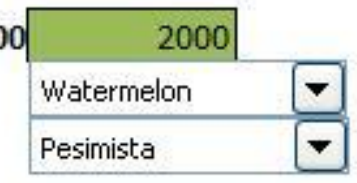

Precio:

Production:(produccion)

$\mathrm{kg} / \mathrm{m} 2$

Resumen:

\begin{tabular}{l|c}
\hline Costo de Producion/kg & 2.10 \\
\hline SALES QUANTITY & 20000.00 \\
\hline TOTAL REVENUES & 85620.00 \\
\hline PROFIT B/F TX & 85620.00 \\
\hline PROFIT A/TX & 60903.00 \\
\hline BEP & 239334.41 \\
\hline IRR & $10 \%$ \\
\hline NPV & 48.05 \\
\hline
\end{tabular}




\section{PROJECT ANALYSIS}

\section{WATER MELON \\ Introduce:(introduce)}

Tamańo del Invernadero Greenhouse Size between 250sqm-500

Cultivo : (Crop)

Escenario: (Scenario)

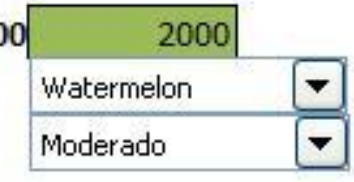

Precio:

Production:(produccion)

$\mathrm{kg} / \mathrm{m} 2$

10

\begin{tabular}{l|c}
\hline \multicolumn{2}{l}{ Resumen: } \\
\hline \multicolumn{2}{|c}{2.10} \\
\hline Costo de Producion/kg & 20000.00 \\
\hline SALES QUANTITY & 106420.00 \\
\hline TOTAL REVENUES & \\
\hline PROFIT B/F TX & 106420.00 \\
\hline PROFIT A/ TX & 74423.00 \\
\hline BEP & 199564.14 \\
\hline IRR & $13 \%$ \\
\hline
\end{tabular}




\section{PROJECT ANALYSIS}

\section{WATER MELON}

Introduce:(introduce)

Tamaño del Invernadero Greenhouse Size between 250sqm-500

Cultivo : (Crop)

Escenario: (Scenario)

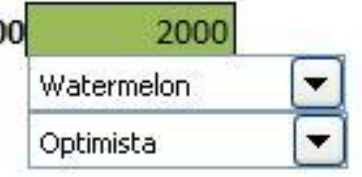

Precio:

8.008

Production:(produccion)

$\mathrm{kg} / \mathrm{m} 2$

10

\begin{tabular}{l|c}
\hline \multicolumn{2}{l}{ Resumen: } \\
\hline Costo de Producion/kg & 2.10 \\
\hline SALES QUANTITY & 20000.00 \\
\hline TOTAL REVENUES & 127220.00 \\
\hline PROFIT B/F TX & 127220.00 \\
\hline PROFIT A/ TX & \\
\hline BEP & 87943.00 \\
\hline IRR & 171127.78 \\
\hline NPV & $16 \%$ \\
\hline
\end{tabular}




\section{Appendix C}

\section{Plan for different month Fixed-Interest-Rate Loan in the spread sheet developed}

Example For 14-month Loan (English version)

\begin{tabular}{ll|}
\hline Bank: $[$ Banco Azteca & Spanis \\
Version
\end{tabular}

Re-payment Plan for a 36-Month Fixed-Interest-Rate Loan

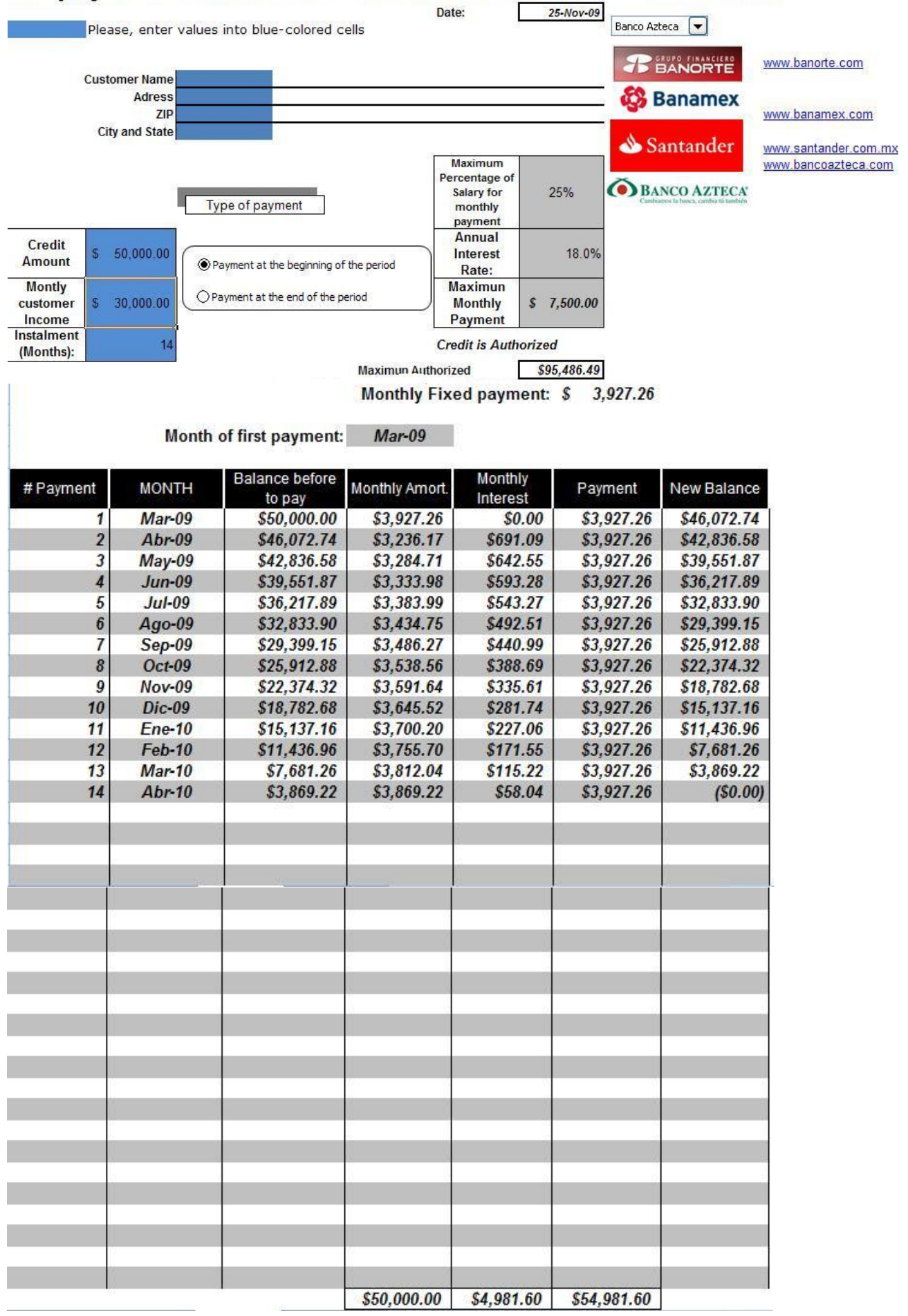


Example For 20-month Loan (Spanish version)

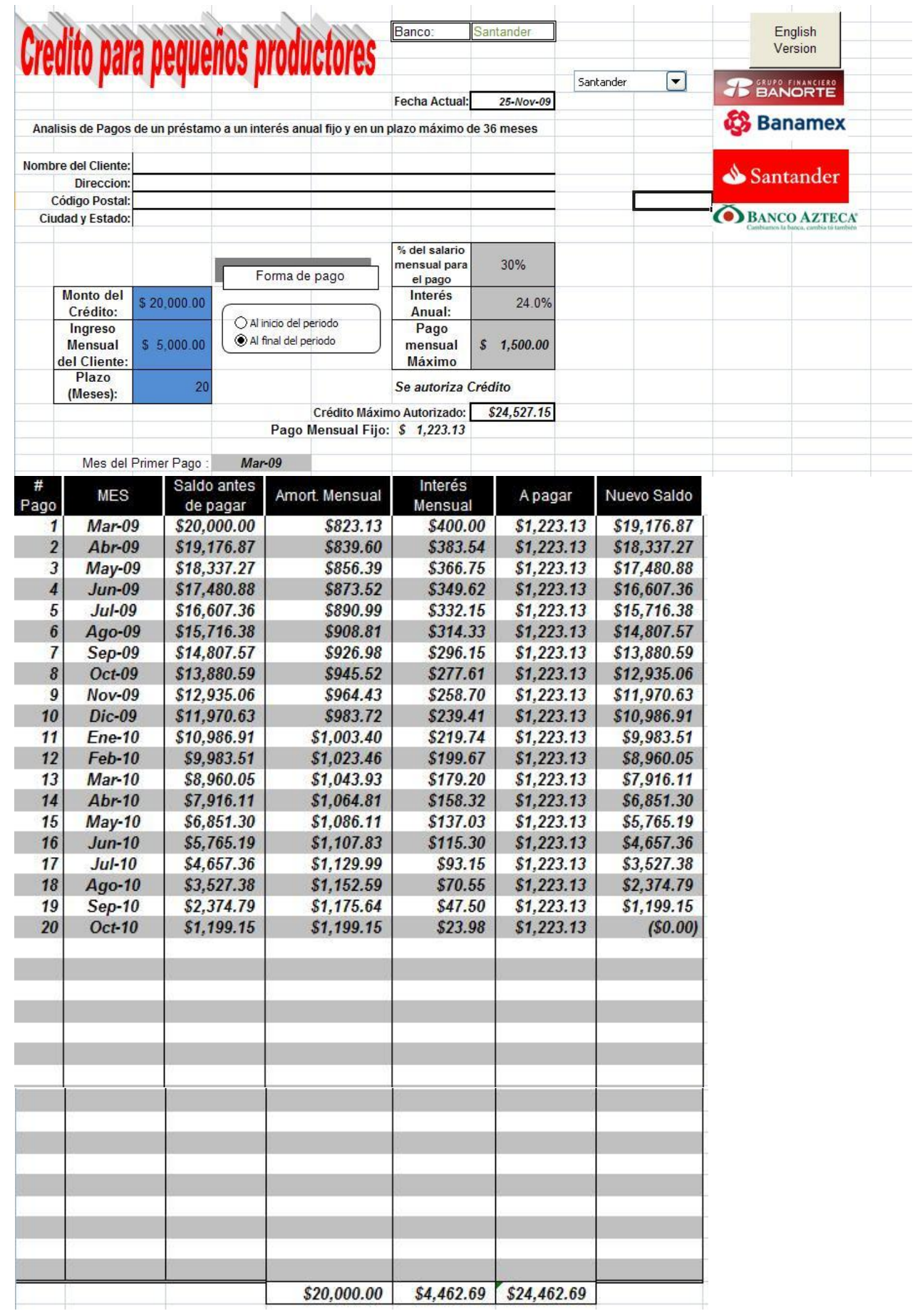




\section{Appendix D}

\section{Greenhouse Construction Structural typology of greenhouses in Mexico}

Source. Engineering Faculty UAQ, 2006

\section{Greenhouse Construction}

Crop production under greenhouses is a specialization of horticulture, developed as a result of technology advances (plastic film appearance) and the exigency of economically strong groups which demanded quality products even off season. Nowadays as a result of the big production under greenhouse, these products are not anymore exclusive of privileged classes and are supplied to a big part of population. (Bakker)

The distinctive characteristic of production under greenhouse compared against open field production is the presence of a physic barrier between inside and external environment. This barrier creates a micro-weather under the greenhouse, protect the crop against the wind, precipitation, weeds, animals and diseases, furthermore it lets the producer to control the internal environment, an impossible situation in open field production. This barrier permits to heat the inside part of the greenhouse, inject carbon dioxide and use effectively chemical and biological products for the protection of the crop. (Bakker)

When a crop is covered with a structure, some important changes happen in the internal weather of the greenhouse. The most important effect is the reduction of the wind speed compared with open field production. This is the true "Greenhouse effect". Although the cover will influent in a significant way the energy interchange, specially the energy that go out of the greenhouse, this is less in relation with air movement. The effect of the cover due to the reduction of energy transferred by the wind, its reflected in the increase of intern temperature. (Hanan) 
The presence of this physic barrier, causes desired and undesired effects, a change of weather conditions compared with the exterior: solar radiation and wind speed reduced, the temperature and vapour pressure rises, and the fluctuations in carbon dioxide are bigger. These passive inherent changes in the greenhouse weather, traditionally referred as the greenhouse weather, combined with external fluctuations force the producer to try to control the inner weather. (Bakker)

Greenhouse industry in Spain is a good example of an agrosystem of Mediterranean greenhouses with a low level technology used. In the most of the cases, the use of simple structures, a low technology level, and the lack of equipments to control the weather, produces a strong dependency of the micro-weather of the greenhouse and external conditions. (Serrano)

\section{Greenhouse purpose}

Greenhouse has a main purpose: To provide and maintain the internal environment helping to the crop growing, creating a proper ambient for the crop and a comfortable work area.

Efficiency and functionality are the two main characteristics of greenhouses. Efficiency is understand as the capacity to control the main environment elements according to physiologic exigencies of the crop. The functionality is the group of requisites which permits the best use o the greenhouse. These characteristics must harmonize to define the greenhouse as the production system capable of obtain harvest out of the normal market season. It is necessary to reach this objective, to analyse the human and nature resources available in the greenhouse zone, make a study of opportunity markets for the greenhouse products. (Matallana)

It will be always recommendable to develop preliminary sketches to evaluate different arrangements (greenhouse location and auxiliary buildings) to choose de best one. Below are mentioned some important points to make the sketches. 
1. Service structures must be located at north to minimize shadow in the greenhouse.

2. Separate client and supply traffic.

3. Sales area must be located preventing that customers have not access to production zone.

4. Situate wind breaker at least 30m from any building.

Independently of the arrangement chosen, the cleanness require special attention, the arrangement must make easy the cleaning of the installation. Sanity is the first line to control diseases. (Hanan, pp-27)
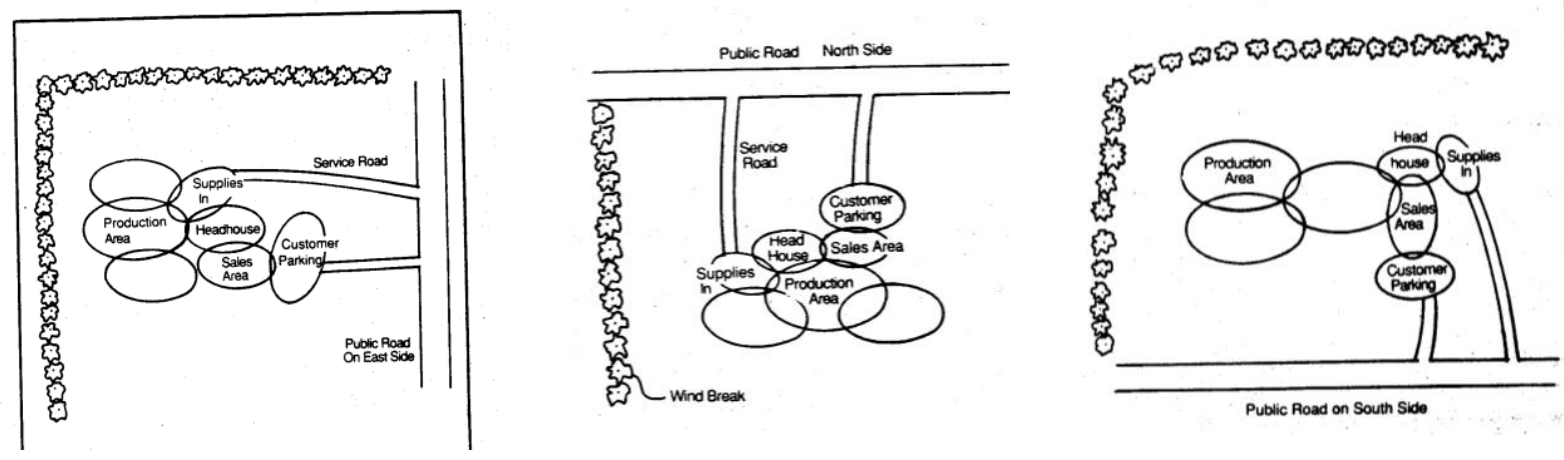

Building sketches

\section{Greenhouse ventilation}

Natural ventilation Free ventilation is just enough in those places and times where wind speed are highly enough [FAO pp-50]

Forced ventilation The ventilation in a greenhouse helps to air interchange between inside and outside atmospheres and fulfil the next functions:

- Oxygen and $\mathrm{CO}_{2}$ Exchange.

- Temperature control

- Humidity control 
Its very important for the best growing of the crop to give it enough ventilation, specially in the case of very high exterior temperature. It is important to distinguish between "natural ventilation", free or static, through ventilation gaps, and the "forced ventilation" using extractors.

Greenhouses can be classified in different ways, according to certain characteristics of their construction elements: (Serrano pp-67)

- Extern profile

- Cover material

- Structure material

The most used classification it's about the structural formation an the external profile, as follows:

Flat

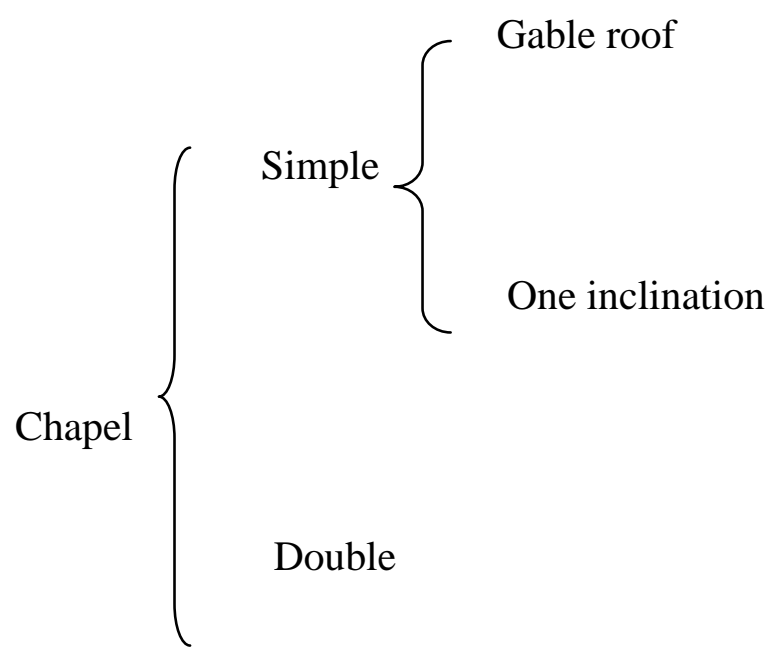


Saw roof $\left\{\begin{array}{l}\text { One tooth } \\ \text { Many teeth }\end{array}\right.$

Tunnel or semi-cylindrical

Semi Ecliptic

Asymmetric

Flat (Serrano pp-67)

This kind of greenhouse is used in zones of few rains like Almeria, Spain. However, its building is not recommended because it has a lot of disadvantages, the only advantages are construction economy and wind resistance.

\section{Disadvantages are:}

- Small air volume

- $\quad$ Bad ventilation

- Sinking danger because of water accumulation in the roof

- $\quad$ Rain water dropping in the plants

\section{Chapel}

Simple chapel greenhouses have a roof forming one or two inclined planes, depending if it is simple or gable roof.

\section{Advantages of these greenhouses are:}

- Easy building and conservation

- Acceptable for covering with any kind of plastic, rigid as well as flexible. 
- Side windows collocation is very easy, and can be made in big surfaces using easy mechanization.

- Rain water is easy evacuated.

- Junction of different buildings is easy.

\section{Some disadvantages are:}

- In battery buildings it presents ventilation problems.

- Less air volume per surface unit respect to curved greenhouse with the same wall height. (Serrano pp-69)

\section{Double chapel}

Double chapel greenhouses are formed by two juxtaposed. These double chapel greenhouses are really well ventilated. (Serrano pp-70)

\section{Saw-tooth roof}

This kind of greenhouse if formed by the battery union of simple inclined buildings. The angle of the planes must be of $30^{\circ}$ approx.

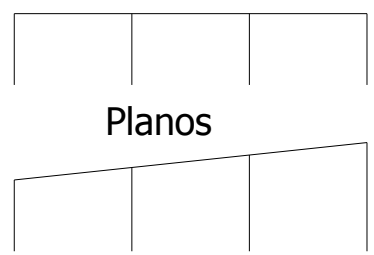

A un agua

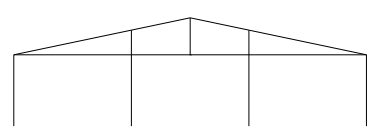

A dos aguas

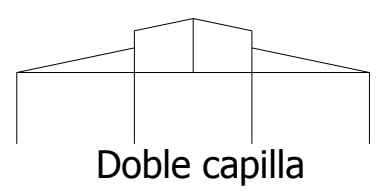

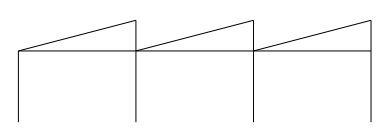

Diente de sierra

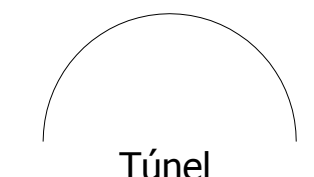

Túnel

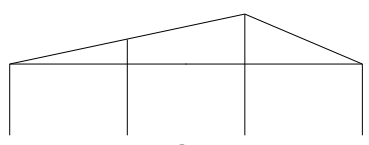

Asimétrico 


\section{Appendix E}

\section{Application for Permit to Import Plants or Plant Products in USA}

Instructions for completing PPQ Form 587

Application for Permit to Import Plants or Plant Products(USDA,2008)

1. Enter the name and street address of the person responsible for the importation. The applicant must be a United States resident. Enter the organization or company name, if applicable. A physical address of the facility or business is required. You may include a post office box address in addition to the street address for mailing purposes. Enter your daytime telephone number, including the Area Code. Enter your facsimile number, including the Area Code. Enter your e-mail address if applicable.

2. In the first column, enter a country or countries (if from Canada include Province, if from Mexico include State) from which you want to import the plants or plant products (the term "various" will not be accepted). In the second column, enter the scientific (Latin) name of each plant. If you do not know the scientific name(s), try to find out from the exporter. As a last resort, enter the English common name(s). In the third column, enter the type of plant parts you plan to import for each species. In the fourth column, enter the City and State of the preferred port(s) of arrival. If you do not know the port, enter "N/A." (Check your permit when you receive it for the approved ports.)

3. Check the appropriate box. Select "Plants for planting", if the plants/plant parts you want to import will be planted or sold for planting. Select "Small lots of seed" if you want to import under the small lots of seed program (see below*). Select "Fruits and Vegetables" if you are importing fruits and vegetables for consumption or resale. Select "Other" if the article you want to import does not fall into any of the other categories. List the category or additional information needed to describe the article (i.e., Cut flowers, broomcorn, etc...). * 
Special instructions for small lots of seed: Small lots of eligible seed may be imported without a phytosanitary certificate with a written permit. See the permit unit website (http://www.aphis.usda.gov/import_export/plants/plant_imports/ smalllots_seed.shtml) for help in determining eligibility. In part \#2 list the seed species and countries from which you want to ship each species. If the list of species and/or countries of origin is long, you may enter "eligible taxa." By using this option, you are accepting responsibility for determining the eligibility of the seeds. A permit is issued for taxa that are enterable with no restrictions beyond port of entry inspection. If port of entry inspectors find prohibited or restricted seeds in your shipment, they will remove the ineligible kinds.

4. Check the appropriate box or boxes that apply to the means of importation.

5. The applicant named in box \#1 must sign the form.

6. Printed name of person who signed the form.

7. Enter the date the form is completed and signed. 